\title{
DIAGNÓSTICO LABORATORIAL DA RAIVA EM EQÜÍDEOS E IMPLICAÇÕES NO TRATAMENTO HUMANO PÓS-EXPOSIÇÃO
}

\author{
Maria Luiza Carrieri
}

Tese apresentada à Faculdade de Saúde Pública da Universidade de São Paulo, para obtenção do Título de Doutor em Saúde Pública Área de concentração: Serviços de Saúde Pública

ORIENTADOR: PROF. DR. PEDRO MANUEL LEAL GERMANO

SÃo PAULO

2004 
À minha mãe Yolanda, pessoa iluminada Ao meu pai que, se estivesse entre nós, seria meu maior entusiasta 
Uma tese é o trabalho, aparentemente individual, mais coletivo que eu conheço. Aos meus irmãos e irmãs, sobrinhos queridos, amigos, colegas que direta ou indiretamente participaram deste trabalho, seja pelo carinho, incentivo, colaboração, palpites, torcida,apoio, paciência...dedico esta tese. 
Às pessoas que são verdadeiras pedras preciosas em minha vida... 


\section{Agradecimentos}

Ao Professor Doutor Pedro Manuel Leal Germano,pela confiança em mim depositada.

À Diretoria do Instituto Pasteur de São Paulo, em nome da Dra. Neide Y. Takaoka, pelo apoio.

À Ivanete Kotait, pelo precioso incentivo, sugestões e amizade.

Aos médicos veterinários responsáveis pela coleta das amostras que fazem parte deste estudo, em especial ao Armando Salvador, ao Rodrigo Silva Bertini, ao Antônio de Souza Braga, à Bárbara Elkhoury, pela colaboração e profissionalismo.

Ao Mateus L.Barradas Paciência por tornar, para mim, a estatística algo tão estimulante.

À Zélia M.P.Peixoto, pelo apoio em todos os momentos.

À Rosângela, Fátima, Samira, Sílvio, Karin, Cida, por participarem, com dedicação, das várias etapas deste trabalho.

Aos pesquisadores, técnicos, estagiários e bolsistas da Seção de Diagnóstico do Instituto Pasteur, pelo espírito de equipe.

À Dra. Maria Mércia Barradas, pelo carinho e estímulo. 
Carrieri ML. Diagnóstico laboratorial da raiva em eqüídeos e implicações no tratamento humano pós-exposição. São Paulo; 2003 [Tese de Doutorado - Faculdade de Saúde Pública da Universidade de São Paulo]

\section{RESUMO}

A raiva é uma antropozoonose transmitida ao homem pela inoculação do vírus da raiva, contido na saliva de animais infectados, através de mordedura. $O$ diagnóstico laboratorial é de fundamental importância para a confirmação de um caso suspeito e, também, para determinar a conduta médica, em relação à necessidade ou não do tratamento anti-rábico humano. As provas diagnósticas devem apresentar elevada sensibilidade e especificidade, bem como rapidez na obtenção dos resultados. A raiva dos herbívoros, transmitida principalmente pelo morcego hematófago Desmodus rotundus, tem apresentado um aumento gradativo no Estado de São Paulo, em particular em eqüídeos, sendo que o diagnóstico clínico apresenta muitas dificuldades, fazendo com que seja imprescindível a remessa de amostras de sistema nervoso central (SNC) para o laboratório. Os testes clássicos de diagnóstico da raiva, quando a amostra a ser processada é de origem eqüina, não apresentam a mesma sensibilidade, quando comparadas com amostras de outras espécies. A Norma de Tratamento Anti-Rábico Humano do Estado de São Paulo recomenda que todas as pessoas que tiverem contato com eqüídeos, que vierem a óbito com suspeita de encefalite, sejam submetidas ao tratamento pós-exposição. Este trabalho objetiva, a partir de testes laboratoriais (imunofluorescência direta e isolamento viral) com diferentes fragmentos do SNC de eqüídeos - córtex (CX), corno de Amon (CA), cerebelo (CB), tronco encefálico (TE) e medula cervical (MD) - identificar o fragmento para o qual as duas técnicas apresentam maior sensibilidade, e correlacionar a intensidade da fluorescência nos diferentes fragmentos com o isolamento de vírus em glândulas salivares e, também, verificar se as condições de vacinação ou não, e óbito natural ou eutanásia, interferem no diagnóstico laboratorial, utilizando os diferentes fragmentos. A análise dos fragmentos de cinco regiões do SNC de 35 animais, pela técnica de IFD, demonstrou que houve associação entre a concentração de antígenos virais e o tipo de fragmento, sendo que o TE e MD apresentaram maiores concentrações virais do que CA, CX e CB. As condições 
de vacinação ou não, e o óbito natural ou eutanásia, não interferiram no diagnóstico laboratorial. A proporção de camundongos mortos inoculados com suspensões preparadas com os diferentes fragmentos não apresentou diferença significativa, mas demonstrou tendência para maior número de mortos, com os fragmentos de TE e MD. A condição de vacinados e não vacinados, e óbito natural e eutanásia, não interferiram na mortalidade de camundongos, ressaltando que a eutanásia, quando praticada, foi na fase de paralisia. $O$ isolamento do vírus rábico em glândulas salivares de eqǘdeos demonstrou o risco potencial que a doença, nestes animais, representa para humanos e a necessidade do encaminhamento de TE e MD para o diagnóstico laboratorial da raiva nesta espécie. Recomenda-se que os Programas de Controle da Raiva de Herbívoros intensifiquem as ações educativas, para que haja uma maior cobertura vacinal em eqüídeos, visando a prevenção da raiva humana.

Palavras-chaves: raiva, eqüídeos, diagnóstico laboratorial 
Carrieri ML. Laboratorial diagnosis of rabies in equids and its implications on human pos-exposure treatment. São Paulo; 2003 [Doctorate Thesis - University of São Paulo School of Public Health]

\section{SUMMARY}

Rabies is an anthropozoonosis transmitted to man by inoculation of the rabies virus present in the saliva of infected animals through a bite. The laboratory diagnosis is essential to confirm a suspicious case and also to determine the medical care in relation to a human anti-rabies treatment being necessary or not. The diagnostic tests need to have both high sensitivity and high specificity, besides being able to provide quick results. The herbivore rabies transmitted mainly by the Desmodus rotundus vampire bat has shown a gradual increase in the State of São Paulo, particularly in equids. As clinical diagnosis is very difficult, it is essential that samples of the central nervous system (CNS) be sent to a laboratory. When samples being processed are from equines, the classical tests do not have the same sensitivity as with other species. The Manual for Human Rabies Treatment of the State of São Paulo recommends that all persons in contact with equids died with suspicion of encephalitis shall be submitted to a post-exposure treatment. The present study has several objectives, the first one being the evaluation of laboratory tests (direct immunofluorescence and virus isolation) performed with different CNS fragments from equids - cortex (CX), hippocampus (CA), cerebellum (CB), brain stem (TE) and cervical spinal cord (MD), determining the fragment for which the two techniques have the highest sensitivity. It will then be possible to correlate the fluorescence intensity in the various fragments with the virus isolation from salivary glands. Another objective is to determine if the laboratory diagnosis in different fragments is influenced by factors such as being vaccinated or not, natural death or euthanasia. Analyses of five fragments from 35 animals by the direct immunofluorescence technique demonstrated an association between the viral antigen concentration and the type of fragment, TE and MD showing higher concentrations than CA, CX and CB. The condition of being vaccinated or not and a natural death or euthanasia did not interfere with the laboratory diagnosis. There were no significant differences in the mortality rate of mice inoculated with suspensions prepared with the 
various fragments, although a trend was detected for a higher mortality with TE and MD. The condition of being vaccinated or not and a natural death or euthanasia did not interfere with the mice mortality. It should be stressed that animals were euthanized in the paralytic stage. Isolation of the rabies virus in equine salivary glands demonstrated the potential risk the disease in these animals pose to humans and the need to send all the fragments for rabies laboratory diagnosis in this species. The authors recommend that the Herbivore Rabies Control Program should intensify its educational activities, as they will result in wider vaccine coverage in equids thus preventing human rabies.

Key words: rabies, equids, laboratorial diagnosis 


\section{LISTA DE ABREVIAÇÕES}

IFD - Imunofluorescência Direta

IFI - Imunofluorescência Indireta

IVC - Isolamento Viral em Camundongos

SNC - Sistema Nervoso Central

CA - Corno de Amon

CX - Córtex

CB - Cerebelo

TE - Tronco Encefálico

MD - Medula

SL - Glândula Sublingual

SM - Glândula Submanbibular

P - Glândula Parótida

OPAS - Organização Panamericana de Saúde

WHO - World Health Organization

CVS - Challenge Virus Standard

CDC - Centers for Disease Control and Prevention

CPCR - Coordenação do Programa de Controle da Raiva 
Foram considerados, para a realização da análise, os maiores valores de concentração de antígeno viral verificados entre as três lâminas examinadas pela IFD.

Tabela 1 - Valores observados e esperados ( ) pelo teste de Chi-Quadrado, para a verificação de independência entre concentração viral e fragmento do SNC usado no diagnóstico de raiva de 35 eqüídeos $\left(n=35 ; N_{\text {frag }}=175\right)$

\begin{tabular}{|c|c|c|c|c|c|c|c|}
\hline \multirow{2}{*}{ Fragmento } & \multicolumn{6}{|c|}{ Classe (concentração antígeno viral) } & \multirow[b]{2}{*}{ Total } \\
\hline & 0 & 1 & 2 & 3 & 4 & 5 & \\
\hline$\overline{\mathrm{CA}}$ & $14(8,2)$ & $5(8)$ & $9(5)$ & $2(5,2)$ & $5(7,4)$ & $0(1,2)$ & $35(35)$ \\
\hline $\mathrm{CX}$ & $11(8,2)$ & $7(8)$ & $3(5)$ & $4(5,2)$ & $8(7,4)$ & $2(1,2)$ & $35(35)$ \\
\hline CB & $11(8,2)$ & $11(8)$ & $2(5)$ & $6(5,2)$ & $4(7,4)$ & $1(1,2)$ & $35(35)$ \\
\hline TE & $2(8,2)$ & $10(8)$ & $5(5)$ & $6(5,2)$ & $10(7,4)$ & $2(1,2)$ & $35(35)$ \\
\hline MD & $3(8,2)$ & $7(8)$ & $6(5)$ & $8(5,2)$ & $10(7,4)$ & $1(1,2)$ & $35(35)$ \\
\hline Total & $41(41)$ & $40(40)$ & $25(25)$ & $26(26)$ & $37(37)$ & $6(6)$ & $175(175)$ \\
\hline
\end{tabular}

Os resultados são melhor ilustrados na figura 7 , na qual as concentrações virais tendem a ser menores nos fragmentos $\mathrm{CA}, \mathrm{CX}$ e $\mathrm{CB}$, uma vez que para estes verifica-se um maior número de observações nas classes mais baixas (zero, 1 e 2), quando comparados aos fragmentos TE e MD. As equações das retas sobrepostas aos diagramas de barras, na figura 7, confirmam esta tendência.

Enquanto $\mathrm{CA}, \mathrm{CX}$ e $\mathrm{CB}$ tendem a apresentar uma maior frequência de valores baixos de concentração viral, TE e MD tendem a valores mais homogêneos, com sutis aumentos no número de observações para as classes 3,4 e 5 . 


\section{LISTA DE TABELAS}

Tabela 1 - Valores observados e esperados ( ) pelo teste de Chi-Quadrado, para a verificação de independência entre concentração viral e fragmento do SNC aplicado ao diagnóstico de raiva de 35 eqüídeos $\left(n=35 ; N_{\text {frag }}=175\right)$.

página 53

Tabela 2 - Sensibilidade das técnicas de IFD e IVC para os cinco fragmentos de SNC de 55 eqüídeos. São Paulo, 2000 - 2003.

página 59

Tabela 3 - Análise de correlação, estabelecida entre fragmentos do SNC de 35 eqüídeos, tendo-se como base o número de observações (freqüências) de cada classe de concentração viral nos diferentes fragmentos. São Paulo, 2000 - 2003.

página 60

Tabela 4 - Valores observados e esperados ( ) pelo teste de Chi-Quadrado, para a verificação de independência entre concentração viral e fragmento do SNC aplicado ao diagnóstico de raiva de 32 eqüídeos, considerando se estes animais foram ou não previamente vacinados. São Paulo, $2000-2003$. $\left(n=32, N_{\text {frag }}=160 ; \chi_{(49)}^{2}=63,974, p=\right.$ $0,074)$. 
Tabela 5 - Valores observados e esperados ( ) pelo teste de Chi-Quadrado, para a verificação de independência entre concentração viral e fragmentos do SNC aplicados ao diagnóstico de raiva de 35 eqüídeos, considerando-se se estes animais morreram espontaneamente ou foram submetidos à eutanásia. São Paulo, $2000-2003$. ( $n=35, N_{\text {frag }}$ $=175) ;\left(\chi_{(49)}^{2}=59,614 ; p=0,142\right)$.

página 69 


\section{LISTA DE FIGURAS}

Figura 1 - Ciclos epidemiológicos da raiva.

página19

Figura 2 - Distribuição dos casos de raiva em herbívoros no Estado de São Paulo 19922002.

página 22

Figura 3 - Número de casos de raiva em herbívoros nas Américas 1992-2002.

página 24

Figura 4 - Número de casos de raiva em herbívoros no Brasil 1992-2002.

página 25

Figura 5 - Número de casos de raiva em herbívoros no Estado de São Paulo 1992-2002.

página 25

Figura 6 - Municípios de procedência das amostras de eqüideos analisadas. São Paulo, $2000-2003$.

página 39

Figura 7- Freqüências de observação para seis classes de concentrações virais (na forma de corpúsculo de inclusão) em cinco fragmentos do SNC de 35 eqüideos. A concentração de antígeno viral é diferente entre classes e fragmentos distintos para $\chi_{(20)}^{2}=33,550 ; p=$ 0,029. São Paulo, 2000 - 2003.

A. Corno de Amon; B. Córtex; C. Cerebelo; D. Tronco encefálico; E. Medula. 
Figura 8 - Relações entre a freqüência de observação de diferentes concentrações de antígenos virais, classes $0-5$, e os fragmentos usados para o diagnóstico de raiva em eqüídeos $(n=35)$. São Paulo, 2000-2003.

A. Corno de Amon; B. Córtex; C. Cerebelo; D. Tronco encefálico; E. Medula.

página 62

Figura 9 - Variação das freqüências obtidas para diferentes classes de concentrações virais $(0-5)$, comparadas entre fragmentos usados para o diagnóstico da raiva provenientes de 32 eqüídeos, sendo 18 vacinados e 14 não vacinados. São Paulo, 2000-2003.

A. Corno de Amon; B. Córtex; C. Cerebelo; D. Tronco encefálico; E. Medula.

página 65

Figura 10 - Freqüência de observação para concentrações virais e fragmentos do SNC de 32 eqüideos, sendo 18 vacinados e 14 não vacinados. A. Variação das seis classes de concentrações virais pelos cinco tipos de fragmentos usados no diagnóstico da raiva. $\mathbf{B}$. Variação entre os fragmentos em uma mesma classe CA; CX; CB; TE; MD. São Paulo, 2000-2003.

página 66

Figura 11 - Freqüências de observação para classes de concentrações virais e fragmentos do SNC de 35 eqüideos, sendo que 18 tiveram óbito natural e 17 foram submetidos à eutanásia. São Paulo, 2000-2003.

página 70

Figura 12 - Variação das freqüências experimentais obtidas para diferentes classes de concentrações virais $(0-5)$, comparadas entre fragmentos usados para o diagnóstico da raiva provenientes de 35 eqǘdeos, sendo que 18 tiveram óbito natural e 17 foram submetidos a eutanásia. São Paulo, 2000-2003.

A. Corno de Amon; B. Córtex; C. Cerebelo; D. Tronco encefálico; E. Medula.

página 71 
Figura 13 - Variação da mortalidade de camundongos pós-inoculação com suspensões obtidas a partir de diferentes fragmentos do sistema nervoso de 33 eqüídeos. A linha pontilhada em vermelho indica a proporção média entre todos os fragmentos. São Paulo, 2000-2003.

página 72

Figura 14 - Tendência de variação da mortalidade de camundongos pós-inoculação com suspensões obtidas a partir de diferentes fragmentos do sistema nervoso de 33 eqüídeos. A linha vermelha representa a tendência central existente no conjunto de dados. São Paulo, 2000-2003.

página 73

Figura 15 - Variação da mortalidade de camundongos pós-inoculação com suspensões obtidas a partir de diferentes fragmentos do sistema nervoso de 30 eqüídeos com histórico de vacinação ( $n_{1}=17$ vacinados; $n_{2}=13$ não vacinados). São Paulo, 2000-2003.

página 75

Figura 16 - Variação da mortalidade de camundongos pós-inoculação com supensões obtidas a partir dos diferentes fragmentos do SNC de 33 eqüídeos que vieram a óbito naturalmente ou que foram submetidos à eutanásia após aparecimento dos sintomas. $\left(n_{1}=\right.$ 18 mortos naturalmente; $n_{2}=15$ submetidos à eutanásia). São Paulo, 2000-2003. 


\section{SUMÁRIO}

\section{INTRODUÇÃO}

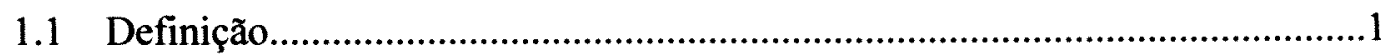

1.2 Histórico

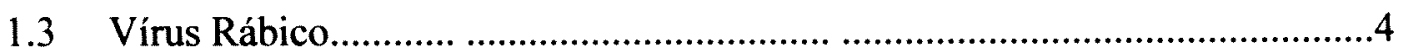

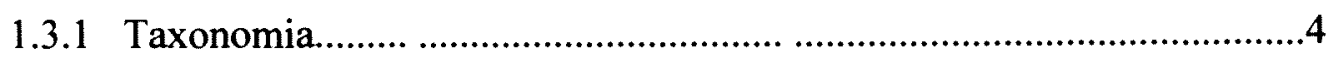

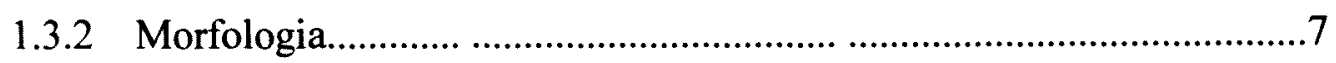

1.3.3 Estrutura......................................................................................

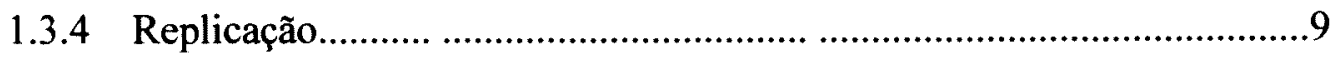

1.3.5 Propriedades...............................................................................10

1.3.6 Patogênese

1.4 Epidemiologia

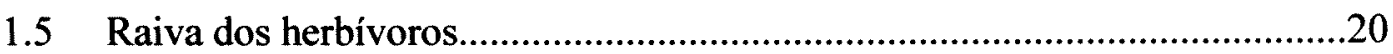

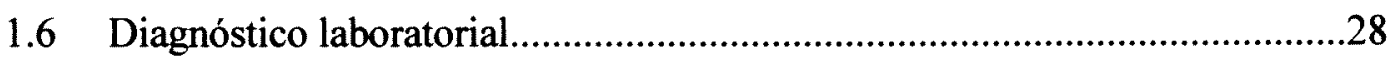

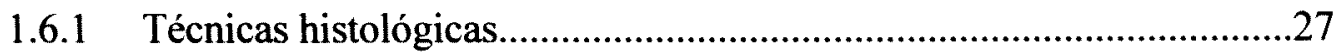

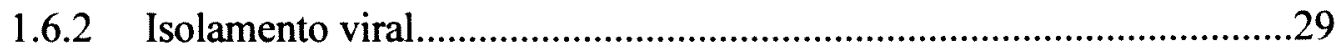

1.6.3 Imunofluorescência direta....................................................................30

1.6.4 Tipificação antigênica........................................................................31

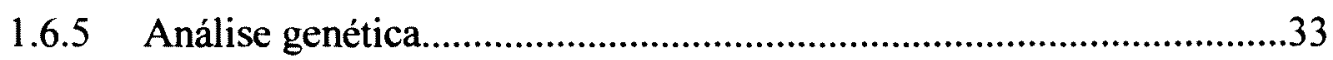

1.7 Tratamento profilático humano.........................................................................

2 OBJETIVOS

\section{MATERIAL E MÉTODOS}

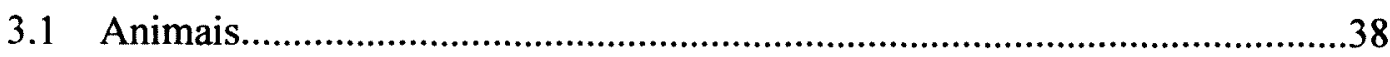

3.1.1 Sistema nervoso central (SNC)......................................................38

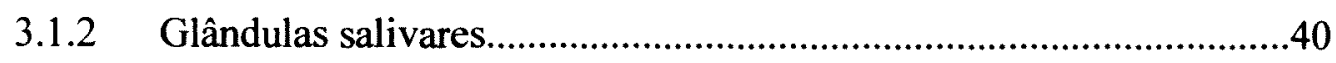


3.1 Técnicas utilizadas no diagnóstico laboratorial para raiva..........................43

3.1.2 Imunofluorecência direta (IFD) ........................................................43

3.1.3 Isolamento viral em camundongos (IVC) ........................................44

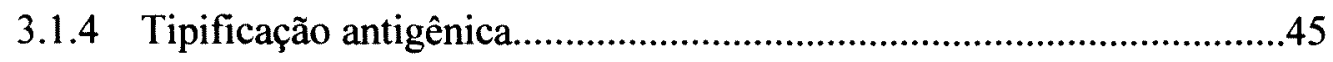

3.2 Tratamento estatístico dos dados..........................................................45

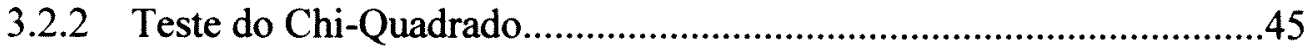

3.2.3 Análise de variância - ANOVA One Way..........................................48

3.2.4 Análise de variância - ANOVA Two Way.....................................49

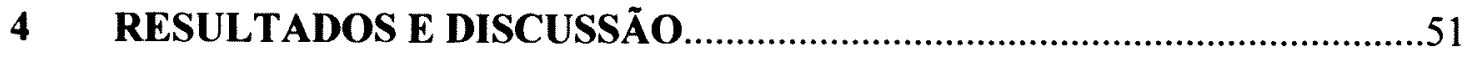

4.1 Análise das concentrações de antígenos virais em distintos fragmentos do

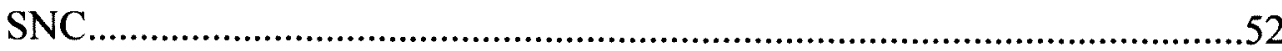

4.2 Análise das concentrações de antígenos virais e histórico de vacinação......64

4.3 Análise das concentrações de antígenos virais e tipo de óbito.....................68

4.4 Análise da prova para isolamento viral ..................................................71

4.5 Análise da prova para isolamento viral e histórico de vacinação..................73

4.6 Análise da prova para isolamento viral e tipo de óbito................................76

4.7 Isolamento viral a partir de glândulas salivares...........................................78

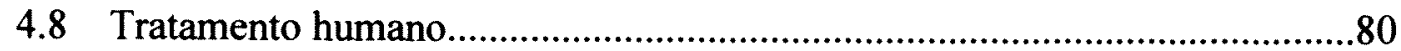

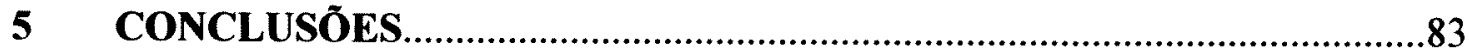

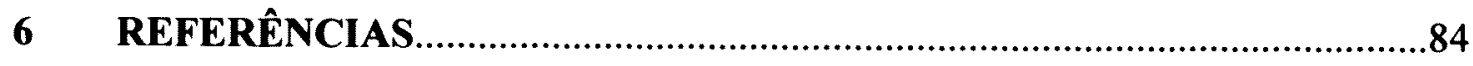

ANEXO 


\section{INTRODUÇÃO}

\subsection{Definição}

A raiva é uma antropozoonose transmitida ao homem pela inoculação do vírus da raiva, contido na saliva de animais infectados, principalmente através de mordeduras. Trata-se de uma encefalite viral aguda, progressiva, que leva ao óbito $100 \%$ dos casos, representando um sério problema de saúde pública e que provoca grandes prejuizos econômicos à pecuária.

\subsection{Histórico}

É uma doença conhecida desde a Antigüidade, sendo seu nome derivado do latim rabere, que significa "enraivecer" ou "vociferar", possivelmente com origem do sânscrito rabhas, que significa "tomar-se violento". Os gregos adotaram sua própria palavra lyssa, que quer dizer "loucura", para a raiva, sendo esta a origem da denominação do gênero Lyssavirus, ao qual pertence o vírus da raiva (WILKINSON 2002).

Os primeiros relatos em documentos legais constam do código de Eshnunna da Mesopotâmia, do século XXIII a.C., quando proprietários de animais, que ficavam soltos, eram penalizados por mortes humanas, conseqüentes às mordeduras de animais raivosos (KOPROWSKI e DIETZSCHOLD 1998; WILKINSON 1988, 2002).

No período compreendido entre IV a.C. e I d.C., Demócrito, Aristóteles, Cornelius Celsus e Galeno descreveram a doença em cães e os princípios da sucção, cauterização e 
incisão cirúrgica das lesões provocadas pelas mordeduras dos animais raivosos (STEELE e FERNANDEZ 1991; WILKINSON 1988, 2002).

A infectividade da saliva de cães raivosos foi descrita pelo romano Cardanus. Os romanos descreviam o material infeccioso como sendo um veneno, cujo correspondente em latim é "Vírus" (STEELE e FERNANDEZ 1991).

Foi Girolano Fracastoro, no século XVI, em sua obra "A Ferida Incurável", que conceituou a raiva como uma doença contagiosa, que levava à morte os indivíduos acometidos. Ele também definiu o periodo de incubação e relacionou-o à gravidade das lesões (KOPROWSKI 1995; KOPROWSKI e DIETZSCHOLD 1998; RUPPRECHT e col. 2002; WILKINSON 2002).

A partir do século XI d.C. ocorreram muitos surtos de raiva canina em vários países da Europa. O primeiro relato de raiva em cães, na Grã Bretanha, se encontra nas leis de Howel, o "Bom", de Gales. Um grande surto ocorreu na Francônia, atual Baviera, região localizada ao sul da Alemanha, quando 30 pessoas morreram após terem sido atacadas por lobos raivosos. No ano de 1500, um novo surto ocorreu na Espanha e, a partir de 1700, a raiva estava disseminada em toda a Europa (STEELE e FERNANDEZ 1991).

O primeiro relato da raiva na América data de 1709, no México, feito por Frei José Ramirez, que sugeriu que a doença foi introduzida no continente americano pelos colonizadores espanhóis, os quais trouxeram seus cães de caça infectados. Há, no entanto, outros relatos do periodo de colonização, que descreveram a morte de vários soldados vitimados por mordeduras de morcegos hematófagos, pertencentes a enormes colônias existentes no continente (SCHLÖGEL 1985). 
Em 1768, ocorreu um surto de raiva canina em Boston, nos Estados Unidos e alguns anos depois houve um outro em humanos, cavalos e suínos no Haiti e na República Dominicana (STEELE e FERNANDEZ 1991).

O primeiro episódio da doença na América do Sul, ocorreu no Peru em 1803, sendo que, a partir deste ano, foram obtidos importantes conhecimentos científicos para o controle desta enfermidade: Zinke (1804) verificou a capacidade infecciosa da saliva de cães raivosos; Krugelstein (1826) descreveu a progressão da raiva até o sistema nervoso central; Youatt (1851) provou a importância do desenvolvimento de vacinas anti-rábicas; Galtier (1879) relatou a transmissão da raiva para coelhos, a partir da inoculação de saliva de cães raivosos, e a transmissão de coelhos para coelhos (WILKINSON 2002).

Os trabalhos de GALTIER $(1879,1881)$ influenciaram as pesquisas de Louis Pasteur, que juntamente com Émile Roux, Charles Chamberland e Louis Thuieller desenvolveram pesquisas para a obtenção da vacina anti-rábica atenuada, utilizada pela primeira vez, com êxito, no garoto Joseph Meister, de 9 anos, que havia sofrido severas mordeduras de um cão raivoso, na região da Alsácia, sendo então estabelecido o princípio da profilaxia pós-exposição na raiva (PASTEUR 1885).

No século $\mathrm{XX}$, inúmeros eventos propiciaram um enorme avanço no conhecimento da epidemiologia e no diagnóstico da raiva. No Brasil, Antonio Carini foi o primeiro a assinalar a possibilidade de participação dos morcegos hematófagos (Desmodus rotundus) na transmissão da raiva dos herbivoros (CARINI 1911). Este estudo foi desenvolvido na pesquisa de uma grave epizootia de raiva em herbívoros, no Estado de Santa Catarina, que ocorreu a partir de 1908. Tal hipótese foi comprovada por 
HAUPT \& REHAAG, (1925), pela identificação de corpúsculos de Negri, inclusões intracitoplasmáticas patognomônicas da raiva, no sistema nervoso central (SNC) de bovinos que haviam sido sugados por morcegos e morrido com sintomatologia nervosa (HURST e PAWAN 1931; QUEIRÓZ LIMA 1934; TORRES e QUEIRÓZ LIMA $1935,1936)$.

No Estado de São Paulo, os primeiros casos de raiva em herbívoros foram descritos em 1935, nos municípios de Ubatuba e Itu (CARNEIRO 1936).

Posteriormente, foram identificados muitos surtos de raiva no Brasil, em cães e gatos e em herbívoros. Mais recentemente, com um melhor controle da raiva canina e felina (ANEXOS 1 e 2) e com a intensificação da vigilância epidemiológica da raiva em animais silvestres, foram identificadas várias espécies de morcegos, hematófagos e não hematófagos, infectados pelo vírus da raiva (UIEDA e col. 1996) bem como de silvestres terrestres, havendo forte impacto na saúde pública (KOTAIT 2003).

\subsection{Vírus rábico}

\subsubsection{Taxonomia}

O vírus da raiva é um RNA-vírus, de fita simples (ssRNA), polaridade negativa, não segmentado, pertencente à ordem Mononegavirales. Esta ordem é constituída de 4 famílias: Filoviridae, Paramyxoviridae, Bornaviridae e Rhabdoviridae. À família Rhabdoviridae pertence um amplo número de espécies de vírus que infectam animais vertebrados (mamíferos, peixes e répteis), invertebrados e plantas, o que demonstra a grande diversidade desta família (VAN REGENMORTEL e col. 2000; RUPPRECHT e col. 2002). 
A família Rhabdoviridae possui seis gêneros, sendo que três deles infectam mamíferos:

- Vesiculovirus: vírus da estomatite vesicular e vírus relacionados;

- Lyssavirus: vírus da raiva e aparentados ao vírus da raiva e

- Ephemerovirus: vírus da febre efêmera dos bovinos.

Além destes, há outros 3 gêneros: Novirhabdovirus, que infecta peixes (vírus da necrose infecciosa hematopoiética); Cytorhabdovirus (vírus da necrose amarela da alface) e Nucleorhabdovirus (vírus do nanismo amarelo da batata), que infectam plantas e invertebrados (VAN REGENMORTEL e col. 2000).

No gênero Lyssavirus foram definidos quatro sorotipos, após a realização de testes de imunidade cruzada em camundongos (SCHNEIDER e col. 1973) e determinação de perfis antigênicos utilizando anticorpos monoclonais (WIKTOR e col. 1973, 1980; WIKTOR e KOPROWSKI 1978, 1980; FLAMAND e col. 1980a, 1980b).

Até o ano de 1992, o gênero Lyssavirus era classificado em sorotipos: o sorotipo 1, que compreendia o vírus clássico da raiva, e os denominados "vírus relacionados à raiva", o sorotipo 2 "Lagos Bat", o sorotipo 3 "Mokola" e o sorotipo 4 "Duvenhage" (BOURHY e col. 1990, BOURHY 1992; TORDO 1996).

Os vírus isolados de morcegos na Europa, "European Bat Lyssavirus", foram identificados como vírus aparentados ao vírus rábico, sem, no entanto, serem classificados em outro sorotipo (SCHNEIDER 1982).

A partir daí, com os avanços dos estudos antigênicos e genéticos, passou-se a utilizar a nomenclatura de "genótipos" (BOURHY e col. 1992; VAN REGENMORTEL e col. 2000). O gênero Lyssavirus possui, atualmente, sete espécies distintas. A espécie 
Rabies virus (RABV), representada pelos vírus clássicos da raiva, que infectam mamíferos terrestres, morcegos hematófagos e morcegos não hematófagos das Américas, e pertence ao genótipo 1. A espécie Lagos bat virus (LBV), ou genótipo 2, vírus isolado de morcegos frugívoros da região de Lagos, Nigéria. A espécie Mokola virus (MOKV), ou genótipo 3, que foi isolado de mussaranhos e humanos, também da Nigéria, e felinos do Zimbabwe e Etiópia. A espécie Duvenhage virus (DUVV), ou genótipo 4, inclui vírus isolados de morcegos insetívoros e humanos da África do Sul. (VAN REGENMORTEL e col. 2000).

A partir da década de 1980, verificou-se que os vírus dos genótipos 2, 3 e 4 denominados vírus relacionados ou aparentados ao vírus da raiva - pareciam estar mais difundidos do que se supunha inicialmente. Nesta época foram isoladas várias amostras de vírus no continente europeu, com características similares à dos vírus aparentados (BOURHY e col. 1992).

Outros estudos realizados, posteriormente, permitiram a classificação de mais duas espécies ou dois genótipos: European bat lyssavirus 1 (EBLV-1), que agrupou os isolamentos do gênero Eptesicus e European bat lyssavirus 2 (EBLV-2), que agrupou os isolamentos do gênero Myotis (BOURHY e col. 1993; WHO 1994).

Em 1996, foi isolada de morcego frugívoro, na Austrália, uma nova espécie, que foi denominada "Australian bat lyssavirus" (ABLV), caracterizada como genótipo 7 (GOULD e col.1998; VAN REGENMORTEL e col. 2000).

Mais recentemente, em 2003, foi descrita uma nova variante (Aravan virus), isolada de um morcego insetívoro Myotis blythi, do Kirguistão (Ásia Central), em 1991, 
tendo sido proposta a classificação do Aravan vírus para um novo genótipo do gênero Lyssavirus (ARAI e col. 2003).

\subsubsection{Morfologia}

O vírus da raiva tem forma cilíndrica, semelhante à bala de um fuzil, simetria helicoidal, com uma extremidade arredondada ou cônica e a outra plana ou côncava e espículas no envelope viral. A partícula viral possui, em média, $180 \mathrm{~nm}$ de comprimento e 75 nm de diâmetro e, as espículas, 9 nm (MATSUMOTO 1962; TORDO 1996).

\subsubsection{Estrutura}

A estrutura do vírus rábico pode ser dividida em duas porções: o ribonucleocapsídeo e o envelope. Do ribonucleocapsídeo fazem parte o RNA e três proteínas: a nucleoproteína $(\mathrm{N})$, a proteína $\mathrm{L}$ e a proteína $\mathrm{P}$ (NS ou M1 ou proteína não estruturada). $\mathrm{O}$ material genético do vírus da raiva é constituído por uma fita simples de RNA, de polaridade negativa que possui 11.932 nucleotídeos e $P M=4,6 \times 10^{6} \mathrm{~d}$, cuja ordem dos genes codificadores é N, P, M, G e L, da extremidade 3' para 5'. A nucleoproteína (proteína $\mathrm{N}$ ) é fosforilada em único sítio, possui 450 aminoácidos e está associada ao filamento de RNA viral, exercendo a função de protegê-lo. É a proteína mais conservada do vírus rábico (TORDO 1996; WUNNER 2002).

A proteína L ("large"), que possui 2.142 aminoácidos, é uma RNA-polimeraseRNA-dependente e tem múltiplas atividades enzimáticas (na síntese do RNA, na metilação, na fosforilação, etc.) necessárias para a transcrição e replicação viral (KAWAI 1977; FLAMAND e DELAGNEAU 1978; TORDO 1996; WUNNER 2002). 
A proteina P (NS ou M1) é uma fosfoproteína, com 297 aminoácidos, e possui duas formas, que interagem com a nucleoproteína no processo de encapsidação viral (SOKOL e col. 1971; TORDO 1996; WUNNER 2002).

O envelope viral é constituído por proteínas associadas que constituem uma camada lipídica: a proteína matriz (M ou M2) possui 202 aminoácidos, está localizada na face interna do envelope, assegura a ligação entre o envelope e a ribonucleoproteína, exercendo um importante papel na replicação; a proteína $\mathrm{G}$, que projeta para o exterior espículas glicosiladas (SOKOL e col. 1971; TORDO 1996; WUNNER 2002).

A proteína mais estudada é a glicoproteina, que é trimérica (GAUDIN e col. 1992), possui 524 aminoácidos, e é responsável pela indução de anticorpos neutralizantes (WIKTOR e col. 1973; DIETZSCHOLD e col. 1982), pela estimulação das células T e pela adsorção vírus-célula (TORDO 1996; MATTOS e col. 2001). A resposta imune específica ao vírus da raiva possui dois componentes: a mediada por anticorpos e a mediada por células (BOURHY e col. 1990; TORDO 1996). Além da glicoproteína $(G)$, responsável pela produção de anticorpos, a nucleoproteína $(N)$ tem importante papel na resposta imune, visto que, através de uma interação, age na resposta imune celular. Ressalta-se que uma adequada relação $N / G$, na suspensão antigênica destinada à produção de vacinas, é ideal para obtenção de uma vacina anti-rábica eficiente, visto que atua estimulando a imunidade humoral e a celular (WHO 1992).

Há duas formas de glicoproteína: a insolúvel (GI) e a solúvel (GII). Embora as duas sejam antigenicamente idênticas, só a proteína completa (GI) é capaz de induzir imunidade (DIETZSCHOLD e col. 1983). 


\subsubsection{Replicação}

A adsorção vírus-célula é feita pela glicoproteína, presente na membrana viral, em uma ligação específica (receptor celular - anti-receptor viral). Os receptores celulares variam conforme a célula, sendo, nas células musculares, o receptor nicotínico da acetilcolina (AchR) e, nos neurônios e fibroblastos, os componentes contendo oligossacarídeos e lipoproteínas (ácido siálico dos gangliosídeos). O anti-receptor viral é a glicoproteína $\mathrm{G}$. $\mathrm{O}$ vírus penetra nas células por um processo de endocitose, podendo o ácido nucléico ser liberado do nucleocapídeo ou o nucleocapsídeo pode permanecer intacto e funcionando. Como resultado da fusão do envelope, o nucleocapsídeo intacto, livre do envelope, é depositado no citoplasma da célula. O RNA, que possui polaridade negativa, não é infeccioso, necessitando ser transcrito, através das proteínas $\mathrm{L}$ e $\mathrm{P}$, em moléculas complementares positivas (RNA mensageiro), que codificam 5 proteínas e novos genomas (TORDO 1996; MATTOS e col. 2001).

Esta transcrição é feita pela proteína L, e ocorre da extremidade 3' em direção à extremidade $5^{\prime}(\mathrm{N}, \mathrm{P}, \mathrm{M}, \mathrm{G}, \mathrm{L})$, produzindo seqüencialmente os transcritos monocistrônicos: o RNA líder e depois os 5 RNAs mensageiros codificadores para as proteínas estruturais. Assim que as proteínas são sintetizadas, a replicação pode se efetuar, os RNAs sintetizados são encapsidados e as novas partículas virais saem por brotamento, ao nível da membrana celular, onde as proteínas virais se acumularam (FLAMAND e DELAGNEAU 1978; TORDO 1996; MATTOS e col. 2001). As proteínas virais específicas do envelope são sintetizadas durante a fase tardia de síntese protéica e são inseridas na membrana celular. O nucleocapsídeo associa-se com a 
superficie interior da membrana plasmática alterada, já contendo proteínas virais (TORDO e col. 1996; MATTOS e col. 2001).

É necessário distinguir entre os vírus clássicos da raiva: o vírus de "rua" e o vírus "fixo" (CVS, PV, PM, etc.). Utiliza-se a denominação de vírus de "rua" para amostras que se caracterizam por um período de incubação variável, às vezes bastante prolongado, ao contrário das amostras denominadas vírus "fixo", que apresentam um período de incubação curto, geralmente de 4 a 7 dias, utilizadas na produção de vacinas e como vírus padrão para testes laboratoriais (KAPLAN 1996).

\subsubsection{Propriedades}

O vírus da raiva é muito sensível aos agentes físicos e químicos e solventes de lipídeos (sabão, éter, clorofórmio e acetona), ao etanol 45-70\%, aos preparados iodados e aos compostos de amônio quartenário. Outras relevantes propriedades são: a resistência à dessecação, assim como a congelamentos e descongelamentos sucessivos, relativa estabilidade em $\mathrm{pH}$ entre $5 \mathrm{e} 10$, sensibilidade às temperaturas de pasteurização e à luz ultravioleta. É inativado à temperatura de $60^{\circ} \mathrm{C}$, em 35 segundos; a $4^{\circ} \mathrm{C}$, se mantém infectivo por dias; a $-70^{\circ} \mathrm{C}$ ou liofilizado a $4^{\circ} \mathrm{C}$ se mantém durante anos (KAPLAN 1996).

\subsubsection{Patogênese}

A patogenia da raiva é semelhante em todas as espécies de mamíferos. A penetração viral pela via cutânea ocorre, geralmente, através da mordida de um animal infectado ou pelo contato da saliva contaminada com mucosas ou ferimentos recentes. $\mathrm{O}$ 
ciclo infeccioso inicia-se após a adsorção da glicoproteína viral à membrana citoplasmática da célula do hospedeiro, nos receptores específicos como o receptor nicotínico da acetilcolina - AChR - (LENTZ e col. 1982). Há indicações de que outros receptores de superficie podem ser utilizados para a infecção celular (JACKSON 2002). O vírus se multiplica no local da inoculação, replicando-se inicialmente nas células musculares ou nas células do tecido subepitelial, até que atinja concentração suficiente para alcançar terminações nervosas, sendo este período de replicação extra-neural responsável pelo período de incubação relativamente longo da raiva (BAER e LENTZ 1991).

Nas junções neuromusculares, o vírus rábico - através da glicoproteína - se liga especificamente ao receptor e, após esta fase, atinge os nervos periféricos, seguindo um trajeto centrípeto, em direção ao sistema nervoso central. $O$ vírus segue o fluxo axoplasmático retrógrado (TSIANG 1979; TSIANG e col. 1989) e o transporte é célulaa-célula. Estima-se que o genoma viral tenha um deslocamento de 100 a $400 \mathrm{~mm}$ por dia (TSIANG e col. 1991), até chegar ao SNC. A distribuição do vírus rábico não é homogênea no SNC (SILVA e col. 1974; KISSLING 1975; TRIMARCHI e SMITH 2002) e, por esta razão, a porção de eleição para encaminhamento ao laboratório de diagnóstico varia de espécie para espécie. A predileção por um local de maior replicação pode ser em função da espécie animal, mas também pode estar associada, concomitantemente, à variante do vírus rábico (TRIMARCHI e SMITH 2002). As regiões mais habitualmente atingidas são: hipocampo, tronco cerebral e células de Purkinje no cerebelo; muitas vezes os sintomas estão associados com a localização anatômica do vírus no cérebro (SUREAU e col. 1991; TIERKEL e ATANASIU 1996). 
Recomenda-se que nos herbívoros com suspeita de infecção pelo vírus rábico deva ser coletado todo o encéfalo ou, de preferência, fragmentos do tecido cerebral (córtex, cerebelo e hipocampo ou corno de Amon) de ambos os hemisférios. Segundo TIERKEL (1976) a porção de eleição para se detectar os corpúsculos de Negri é o corno de Amon ou hipocampo.

A partir da intensa replicação no $\mathrm{SNC}$, o vírus da raiva segue em sentido centrífugo, disseminando-se através do sistema nervoso periférico e autônomo para diferentes órgãos (pulmões, coração, rins, bexiga, útero, testículos, folículo piloso, etc.) e glândulas salivares, sendo eliminado pela saliva (CHARLTON 1988; JACKSON 1997). A infecção das glândulas salivares se dá pela via neural, visto que ela possui inervação parassimpática e simpática (JACKSON 2002). Em cães, têm sido possível detectar títulos virais nas glândulas salivares, mais elevados que no cérebro (CHAMELET 1986; JACKSON 1997). Esta infecção das glândulas salivares é de fundamental importância epidemiológica, porque possibilita a transmissão da doença para de muitas espécies animais susceptíveis. $\mathrm{Na}$ maioria dos casos, a eliminação do vírus pela saliva se inicia com a doença, porém em algumas espécies tem-se verificado o aparecimento antes da manifestação dos sintomas clínicos (CHARLTON 1988; CECCALDI e col. 1993; JACKSON 2002). Há, também, casos em que mesmo após a morte não é possível detectar vírus na saliva ou na glândula salivar (FENNER e col. 1992).

A disseminação centrífuga faz com que o vírus atinja, também, terminações nervosas sensoriais do tecido cutâneo da cabeça e pescoço, onde se pode demonstrar a presença de antígeno viral. Por esta razão, utiliza-se a biópsia de tecido desta região 
como método diagnóstico (BRYCESON e col. 1975). O vírus rábico pode localizar-se também nas células da retina e no epitélio da córnea, sendo sua presença demonstrada por imunofluorescência direta (KOCH e col. 1975).

A viremia tem sido documentada em modelos experimentais, sendo fugaz e temporária, mas não há evidências de que tenha importância significativa durante o processo de disseminação viral (ACHA e SZYFRES 1986).

Em cães e gatos, a saliva pode ter maior concentração de vírus que o próprio SNC. Em herbivoros, no entanto, a concentração de vírus eliminado pela saliva é baixa (CHARLTON 1988).

As lesões histopatológicas são as inclusões de Negri, patognomônicas para a raiva. São inclusões acidófilas, com granulações internas basófilas, que podem ser encontradas no citoplasma dos neurônios infectados e são mais freqüentes nos grandes neurônios, como nas células de Purkinje do cerebelo. Elas podem variar, quanto à morfologia, em diferentes espécies, apresentando-se grandes na espécie bovina e pequenas e múltiplas em coelhos (BAER 1991). Sua ausência, porém, não invalida o diagnóstico da raiva, tendo em vista que nos episódios de evolução rápida, com período de incubação curto e óbito precoce, pode não haver tempo suficiente para o seu aparecimento (TRIMARCHI e SMITH 2002). Outra lesão observada é a formação de vacúolos, dando ao sistema nervoso o aspecto espongiforme (CHARLTON 1988; JACKSON 2002)

O período de incubação da raiva é extremamente variável e depende, fundamentalmente, da concentração do inóculo viral, da distância entre o local do ferimento e o cérebro e está relacionado com a extensão, profundidade e localização do 
ferimento causado pelo animal agressor, pois estes fatores têm estreita relação com a inervação e, conseqüentemente, com a presença de receptores. Depende, também, da carga viral e da amostra viral introduzida. É o período que vai desde o momento em que o agente penetra no organismo, até o aparecimento da sintomatologia clínica (ACHA e SZYFRES 1986).

O período de transmissibilidade é o período em que existe a possibilidade de transmissão do agente infeccioso de um organismo a outro. Varia de espécie a espécie, mas, em todos os animais, inclusive nos seres humanos, precede o aparecimento da sintomatologia e perdura durante o quadro clínico, até a morte. Este período foi bastante estudado em cães e gatos, sendo, na grande maioria das vezes, de cerca de 2 a 4 dias antes do surgimento dos sintomas no animal, até sua morte, que ocorre geralmente 5 dias após. Em outras espécies animais o período de transmissibilidade não é conhecido (ACHA e SZYFRES 1986).

Ao contrário de muitos vírus que causam infecção aguda, o vírus da raiva supera as defesas imunes do hospedeiro por um longo período, devido ao seu intenso neurotropismo (KING e TUNER 1993).

Ao penetrar nos neurônios, o vírus da raiva torna-se protegido das células de resposta inespecífica, bem como da ação dos interferons, das células do sistema imune e da ação dos anticorpos (NATHANSON e GONZALES-SCARANO 1991; LAFON 2002). Os interferons são proteínas de baixo peso molecular, que podem atuar inibindo diretamente a replicação viral e, assim, a sua disseminação, ou induzindo as reações das células imunes, sendo extremamente importantes no início da infecção. Depois de uma intensa replicação nas células musculares, ou epiteliais, a concentração de vírus é 
suficiente para invadir as terminações nervosas, mas insuficiente para ser antigênica (KING e TURNER 1993). O vírus da raiva é capaz de induzir a produção de interferons antes de sua migração para o SNC (HILFENHAUS e col. 1975).

As células apresentadoras de antígeno (macrófagos, células dendríticas, células de Langerhans, etc.), quando entram em contato com o vírus da raiva, fagocitam-no e o processam para apresentação às células do sistema imunológico. Esta apresentação é fundamental à produção de anticorpos pelos linfócitos B (KOPROWSKI e col. 1972) e para a ativação dos linfócitos $\mathrm{T}$ auxiliares, que vão produzir diferentes citocinas; estas ativam diferentes células implicadas na eliminação direta do vírus e/ou das células infectadas (CELIS e col. 1986).

$\mathrm{Na}$ raiva, a estimulação dos linfócitos $\mathrm{B}$ para a produção de anticorpos, na infecção natural, só acontece após o aparecimento dos sintomas clínicos. A possibilidade de neutralização da capacidade infecciosa viral só ocorre, portanto, após a invasão do sistema nervoso central e, neste momento, a doença já adquiriu uma forma irreversível. Freqüentemente o título de anticorpos neutralizantes permanece baixo até a fase terminal da doença, sendo detectados apenas no período próximo à morte do hospedeiro (MURPHY 1977).

A ação principal dos anticorpos é a de bloquear o vírus extracelular, antes que ele encontre o receptor das células musculares, inibindo sua propagação ao nível do local de infecção e, conseqüentemente, sua progressão até o SNC (BAER e YANGER 1977; DIETZCHOLD e col. 1987).

A resposta imune celular evidenciada pela primeira vez por WIKTOR e col. (1974) é um mecanismo importante da resposta imune ao vírus da raiva. Os linfócitos T 
participam da proteção de diferentes maneiras: estimulando as células B a produzirem anticorpos através dos linfócitos $\mathrm{T}$ auxiliares; como efetoras de imunidade, na forma de células $\mathrm{T}$ citotóxicas, lisando células infectadas; induzindo a síntese de substâncias mediadoras da estimulação de diferentes células; e como células de memória imunológica (WIKTOR e col.1977; MIFUNE e col.1981; ZANETTI 1994).

\subsection{Epidemiologia}

A raiva possui distribuição mundial, com cerca de 35.000 a 40.000 mortes de humanos ao ano, quase todas em países em desenvolvimento (MESLIN 2002; NANAYAKKARA e col. 2003). A raiva mata, na atualidade, mais pessoas que doenças como a febre amarela, dengue e encefalite japonesa (RUPPRECHT e col. 2002) e, segundo HEMACHUDHA e col. (2002), uma pessoa morre de raiva a cada 15 minutos e, no mesmo intervalo de tempo, outras 300 são expostas ao vírus. As regiões sem ocorrência de raiva na população animal são: Finlândia, Havaí, Islândia, Japão, Nova Guiné, Nova Zelândia, Tailândia, a parte continental da Noruega, Suécia, Portugal, Grécia e algumas ilhas das Antilhas e do Atlântico (BENESON 1997; GOULD e col. 1998; JOHNSON e col. 2003).

Mais de 115 anos após o desenvolvimento da vacina anti-rábica por Louis Pasteur, ainda se depara com a raiva, em algumas regiões, sob a forma epidêmica. A razão mais importante para que este fato ocorra é a multiplicidade de reservatórios, domésticos ou silvestres, sendo que duas subordens apresentam maior relevância: Carnivora e Chiroptera (RUPPRECHT e col. 2002). 
As formas epidemiológicas da raiva obedecem a uma divisão didática, sendo, as mais conhecidas, a raiva urbana, a raiva rural e a silvestre (ACHA e SZYFRES 1986). A raiva urbana é transmitida, principalmente, de cão para cão, sendo o vírus mantido primariamente na população canina, porém outros animais domésticos urbanos são freqüentemente infectados, em especial os gatos. Os cães são os principais transmissores da raiva para o homem, sendo esta forma de transmissão a mais comum, devido ao estreito relacionamento entre as pessoas e seus animais de estimação. Na Ásia, África e América Latina, os cães continuam sendo os mais importantes reservatórios e a raiva humana permanece como um grave problema de saúde pública (MESLIN 2002).

Nos países nos quais foi possível o controle da raiva nos animais domésticos urbanos, os casos em humanos diminuíram, porém os animais silvestres representam um sério desafio a ser vencido. Em raposas, a raiva tem se mostrado endêmica, tanto na Europa como na América do Norte. Outros animais silvestres, como os cangambás, guaxinins e morcegos, na América do Norte, têm assumido enorme importância, porém os dados de ocorrência refletem, principalmente, a atenção que tem sido dada à raiva nesses animais (RUPPRECHT e col. 2002).

$\mathrm{Na}$ América Latina, os morcegos hematófagos, principalmente o Desmodus rotundus, constituem-se nos principais transmissores da raiva para os animais de interesse econômico e atuam como reservatórios do vírus rábico no ambiente rural (MÁlAGA-ALBA 1954; ACHA 1967), embora os cães ainda sejam os principais transmissores da raiva humana (OPAS 2001). Outras espécies de morcegos, principalmente insetivoros, também vêm desempenhando importante papel na transmissão da doença (NOAH e col. 1998; HANNA e col. 2000; FAVI e col. 2002; 
RUPPRECHT e col. 2002). Atualmente, os morcegos se tornaram, em importância, o segundo transmissor da raiva humana na América do Sul (OPAS 2000b, 2001).

A transmissão do vírus da raiva ocorre, geralmente, através da saliva de um animal infectado para outro, embora outras vias sejam relatadas. Outra forma de penetração do vírus é por contato com mucosas, principalmente a respiratória. Este fato foi comprovado em animais em condições naturais, quando foram colocados dentro de grutas, de maneira a não permitir contato direto com morcegos infectados pelo vírus da raiva, que habitavam estes locais (CONSTANTINE 1962). Encontram-se, descritos na literatura, 4 casos humanos de infecção rábica pela via aerógena: dois casos de espeleólogos, que trabalhavam em cavernas densamente povoadas por morcegos infectados, e 2 casos de laboratoristas, que trabalhavam em produção de vacinas (FISHBEIN 1991; GIBBONS 2002 ).

A via oral de transmissão foi verificada em animais de laboratório (CORREAGIRON e col. 1970), cujas fềmeas praticaram canibalismo com filhotes infectados pelo vírus da raiva (SOAVE 1966); em cães que se contaminaram ao ingerirem carcaças de raposas infectadas (CHILDS 2002) e, mais recentemente, em morcegos hematófagos que ingeriram sangue desfibrinado de suínos, adicionado de amostras de vírus rábico (SOUZA 2003).

Relatos de contaminação inter humana foram registrados - 8 casos- através de transplantes de córnea de doadores infectados (JACKSON 2002).

Em quirópteros, as transmissões transmamária e transplacentária foram cogitadas por BAER (1975) e STEECE e CALISCHER (1989) confirmaram a transplacentária, ao isolarem vírus da raiva de feto de morcego insetívoro. 
O ciclo aéreo da raiva apresenta, atualmente, grande importância na manutenção do vírus em uma determinada área geográfica. As diferentes espécies de morcegos, hematófagos ou não, são susceptíveis ao vírus, podendo transmiti-lo e apresentar sintomatologia, que sempre evolui para a morte (MORENO e BAER 1980).

A Figura 1 mostra a inter-relação entre os diferentes ciclos, com o conhecimento que se tem, atualmente, a partir de estudos antigênicos e genéticos.

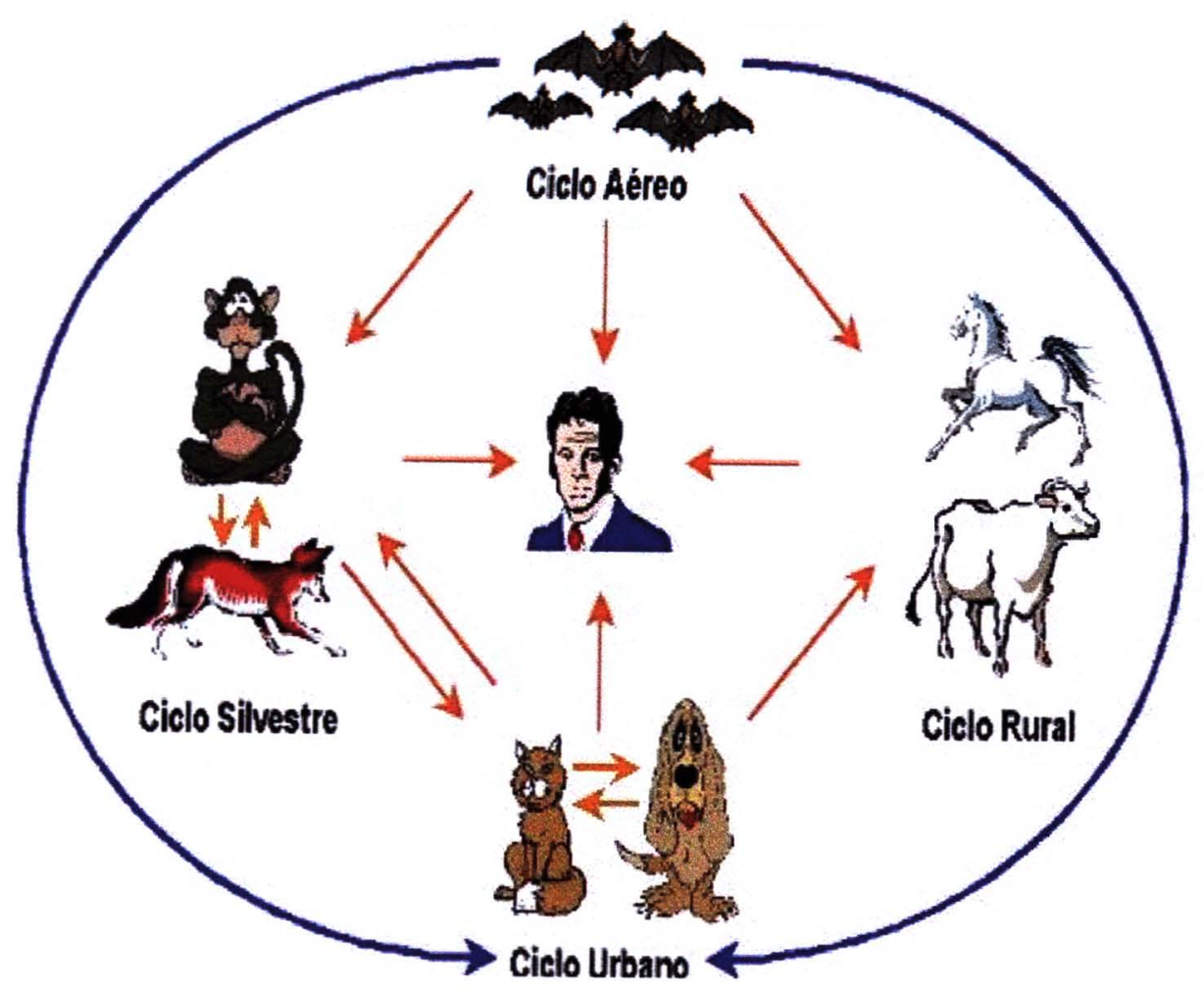

Figura 1 - Ciclos epidemiológicos da raiva

FONTE: Instituto Pasteur 


\subsection{Raiva dos herbivoros}

Com a colonização européia no continente americano, a introdução de animais domésticos, principalmente bovinos e eqüinos, e as alterações ambientais conseqüentes, proporcionaram condições ideais para a proliferação do morcego hematófago Desmodus rotundus (ACHA 1967), que é a principal fonte de infecção da raiva para herbívoros na região tropical das Américas, entre as latitudes $33^{\circ} \mathrm{S}$ e $28^{\circ} \mathrm{N}$ (MÁLAGA-ALBA 1954).

Foi no estudo de um surto de raiva em herbívoros, ocorrido na Ilha de Santa Catarina, a partir de 1908, que se estabeleceu a definitiva relação entre a mordedura pelo morcego hematófago e a ocorrência da raiva bovina e eqüina (CARINI 1911).

ACHA (1967) estimou que cerca de 515.000 cabeças de gado morrem anualmente, vitimadas pela infecção rábica, porém outros autores relatam a morte de mais de 1 milhão (MITCHELL e BURNS 1973).

O Brasil é um dos países que mais tem sofrido as conseqüências da raiva dos herbívoros, fato este agravado pelo elevado número de subnotificações causadas pela falta de conscientização dos produtores e pela ineficiência de uma vigilância epidemiológica dos órgãos oficiais envolvidos no seu controle. A estimativa mais recente indica prejuízos em torno de US\$ 25 milhões de dólares a cada ano no país, com a morte de 40.000 bovinos e perdas indiretas estimadas em US $\$ 37,5$ milhões de dólares (KOTAIT 2001).

O Programa de Controle da Raiva dos Herbívoros é de responsabilidade do Ministério da Agricultura, Pecuária e Abastecimento, que atua nos estados através de convênios, e tem como objetivo o controle da raiva transmitida por morcegos 
hematófagos aos herbívoros. Para o adequado controle da raiva dos herbívoros, três medidas devem ser adotadas sistematicamente: vacinação, controle populacional de morcegos hematófagos e a educação em saúde animal (MINISTÉRIO DA AGRICULTURA 2000).

As freqüentes alterações ambientais provocadas pela atividade humana, incluindo a substituição das matas pela introdução de novas culturas e criações animais, vêm propiciando condições para o estabelecimento de novas populações de morcegos hematófagos (TADDEI e col. 1991).

Atualmente, no Estado de São Paulo as atividades de controle são diferenciadas, em função da situação epidemiológica da doença: áreas epidêmicas, endêmicas e esporádicas (KOTAIT e col. 1998). No período de 1992-2002, praticamente todas as regiões do Estado apresentaram casos de raiva em bovinos e eqüinos (Figura 2). Desde 1997, em algumas regiões do Estado, são realizadas campanhas de vacinação simultâneas de bovinos contra a febre aftosa e a raiva. Este fato fez com que a população bovina venha tendo um nível satisfatório de proteção contra a raiva, não acontecendo o mesmo com a população de eqüídeos, face a não necessidade da vacinação contra a febre aftosa.

No Brasil, com clima tropical, as vacinas inativadas para raiva são as mais adequadas, pela sua inocuidade, termoestabilidade e a qualidade que hoje possuem em termos de imunogenicidade. Tem-se preconizado, para animais primovacinados, o uso de duas doses de vacina inativada, com intervalo de 30 dias, sendo que a primovacinação deve ser feita aos 3 meses de idade, visto que os anticorpos de origem colostral, na maioria dos bezerros provenientes de mães vacinadas, encontram-se em 
níveis satisfatórios para a proteção até, aproximadamente, a idade de 3 meses. Quando os bezerros provêm de mães não-vacinadas, os mesmos devem ser vacinados logo ao nascer, pois embora não possuam um sistema imunológico competente, esta vacinação precoce colaborará, futuramente, com a resposta imunológica por ativação das células da memória (KOTAIT e col. 1998).

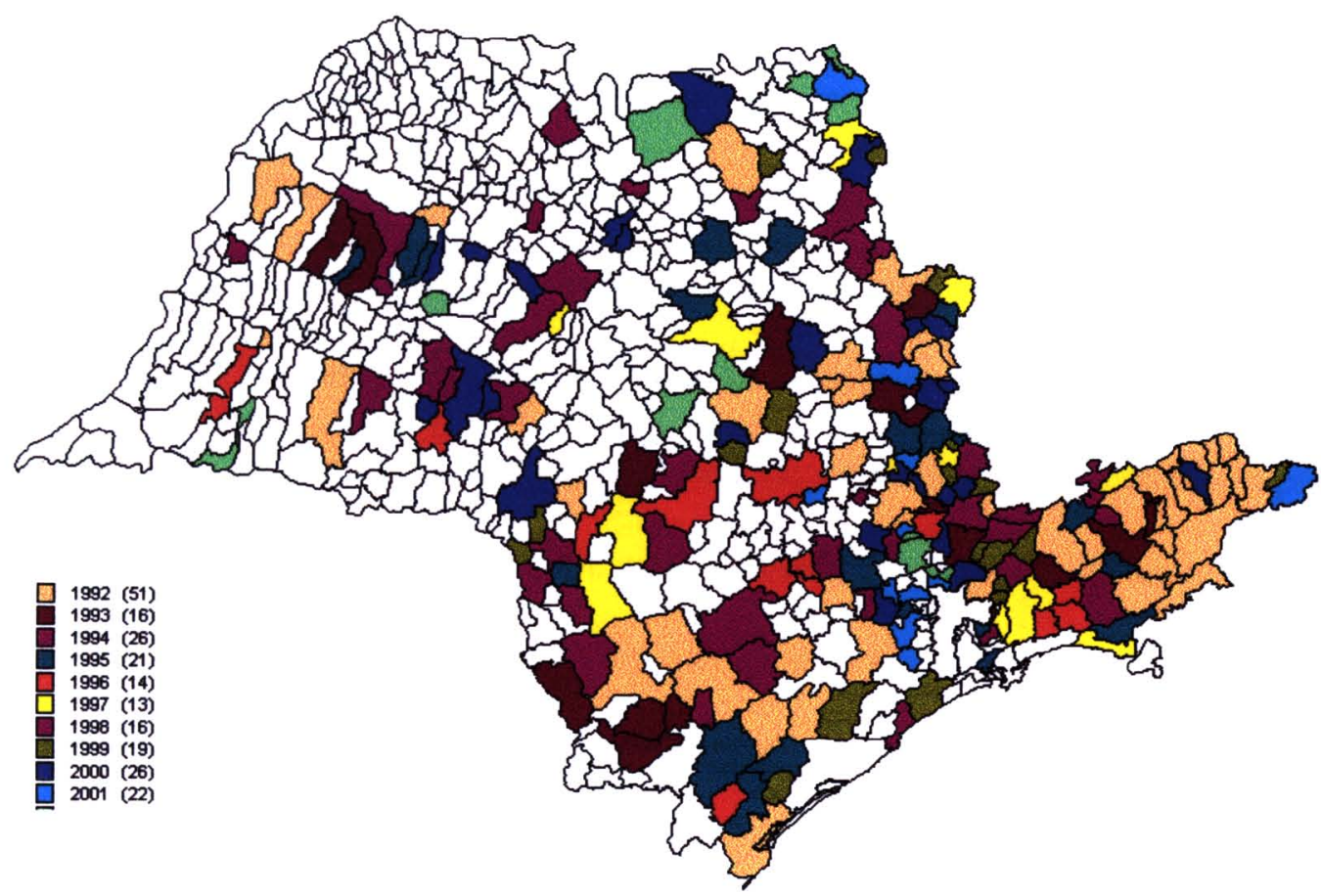

Figura 2 - Distribuição dos casos de raiva em herbívoros no Estado de São Paulo,1992 2002.

Fonte: CPCR/Instituto Pasteur

Deve-se lembrar que a resposta imune de uma população obedece a distribuição normal, isto porque ela é influenciada por um grande número de fatores genéticos e 
ambientais. A grande maioria dos animais tem uma resposta imune média, sendo que alguns respondem excelentemente e outros de forma muito fraca (TIZARD 1998).

Na vacinação feita através de campanhas, a porcentagem de maus respondedores tem uma importância maior ou menor na dependência do agente infeccioso. No caso das doenças altamente infecciosas como a febre aftosa, estes poucos animais que produzem uma resposta imune fraca podem ser suficientes para destruir um programa de controle. No caso da raiva, doença de distribuição não homogênea, estes poucos animais não adquirem a mesma importância na disseminação da doença (TIZARD 1998).

Convém lembrar que mesmo animais que foram vacinados com vacinas eficientes podem se acometidos de raiva. Algumas situações específicas devem ser lembradas: animais vacinados em pleno período de incubação; má aplicação da vacina ou via e dose inadequada; má conservação da vacina; animais geneticamente incapazes de responder; animais com alteração de metabolismo protéico ou parasitados. Pelo exposto, são muitas as razões que fazem com que se atribua à falha vacinal a ocorrência de raiva; porém, na maioria das vezes, esta "falha" não é verdadeira (TIZARD 1998).

O número de casos de raiva de herbívoros teve um grande aumento no período de 1992-2002 na América Latina, no Brasil e no Estado de São Paulo (Figura 3, 4 e 5).

A relação entre o número de casos de raiva bovina e de raiva em eqüídeos, que era 10:1 em 1992, atualmente é cerca de 1:1.

O diagnóstico clínico da raiva bovina, e particularmente da raiva eqüina, apresenta muitas dificuldades (SMITH e CLARE 1972), fazendo com que seja necessária a remessa das amostras de sistema nervoso central para o laboratório, visando o diagnóstico diferencial. Este diagnóstico, na espécie eqüina, deve ser feito entre a 
raiva e as encefalites (Leste, Oeste e Venezuelana), herpesvírus eqüino, toxoplasmose, fusariose, intoxicações, envenenamentos, tétano, etc.

A raiva transmitida pelo Desmodus rotundus é predominantemente paralítica e o período de incubação, nos bovinos e eqüídeos, é de 25 a 90 dias (MÁLAGA-ALBA 1954; ACHA e SZYFRES 1986). Alguns autores consideram a raiva eqüina uma doença silenciosa, uma vez que pode passar desapercebida dos criadores, especialmente pelo curto período da doença, que é, em certos casos, de 12 horas. $O$ fato de a doença não se apresentar de forma característica exige dos veterinários maior atenção para a possibilidade de contatos humanos (STRIEGEL e GENETZKY 1983; WEST 1985; Chomel 1999 citado por CHILDS 2002).

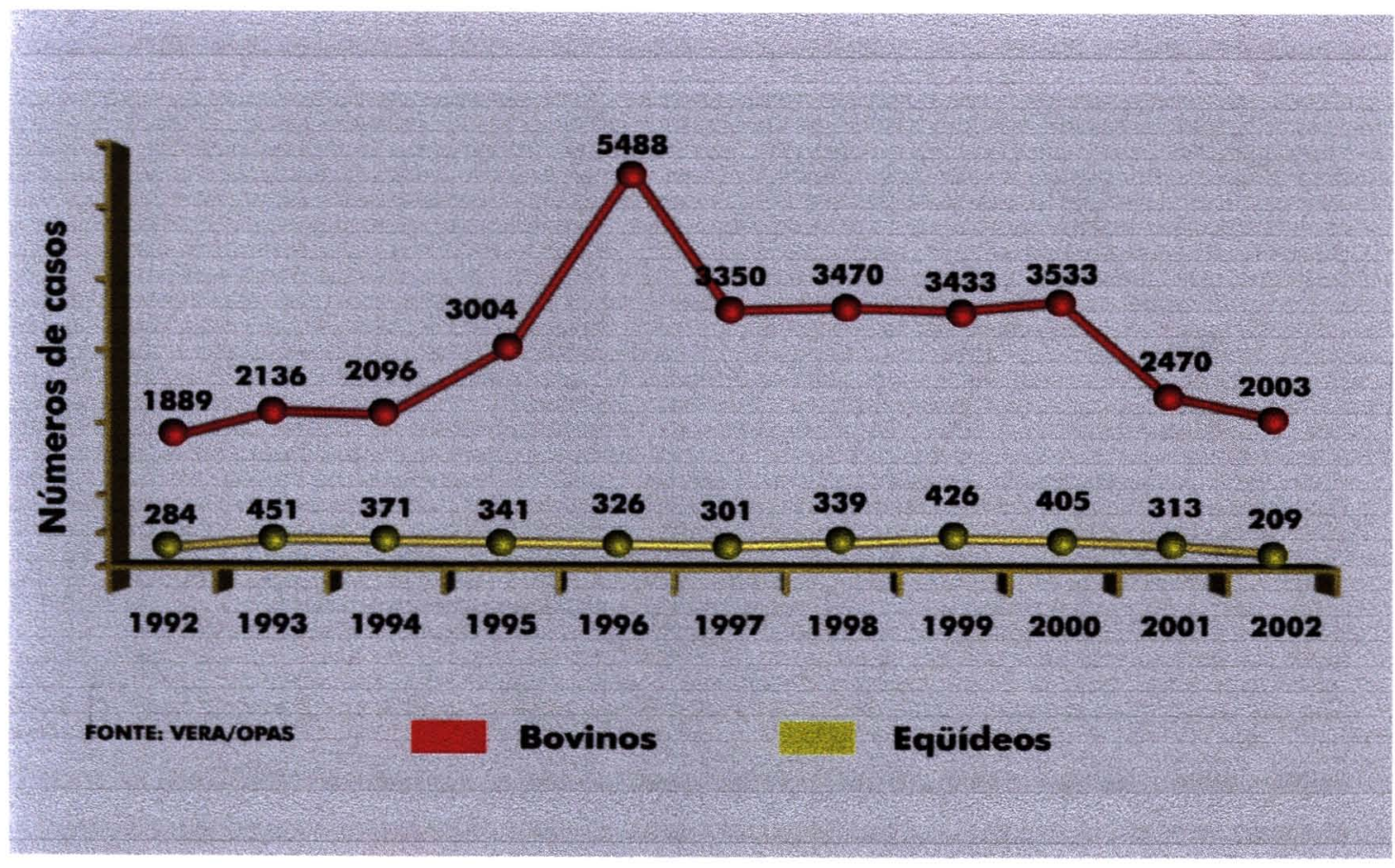

Figura 3 - Número de casos de raiva em herbívoros na América Latina 1992-2002. FONTE: Boletín Vigilancia Epidemiologica de la Rabia en las Américas-OPAS. 


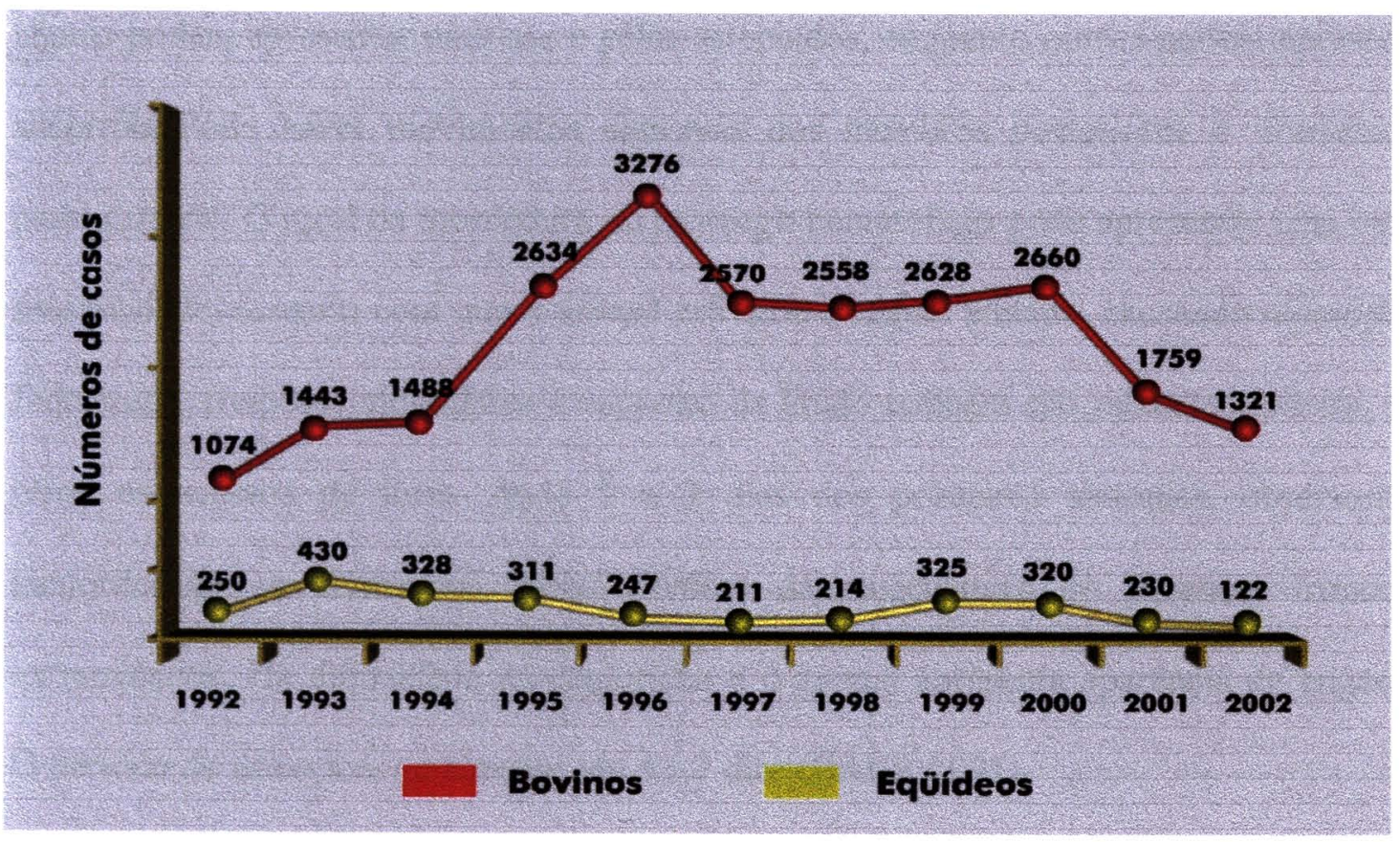

Figura 4 - Número de casos de raiva em herbívoros no Brasil 1992-2002 FONTE: Boletín Vigilancia Epidemiologica de la Rabia en las Américas-OPAS.

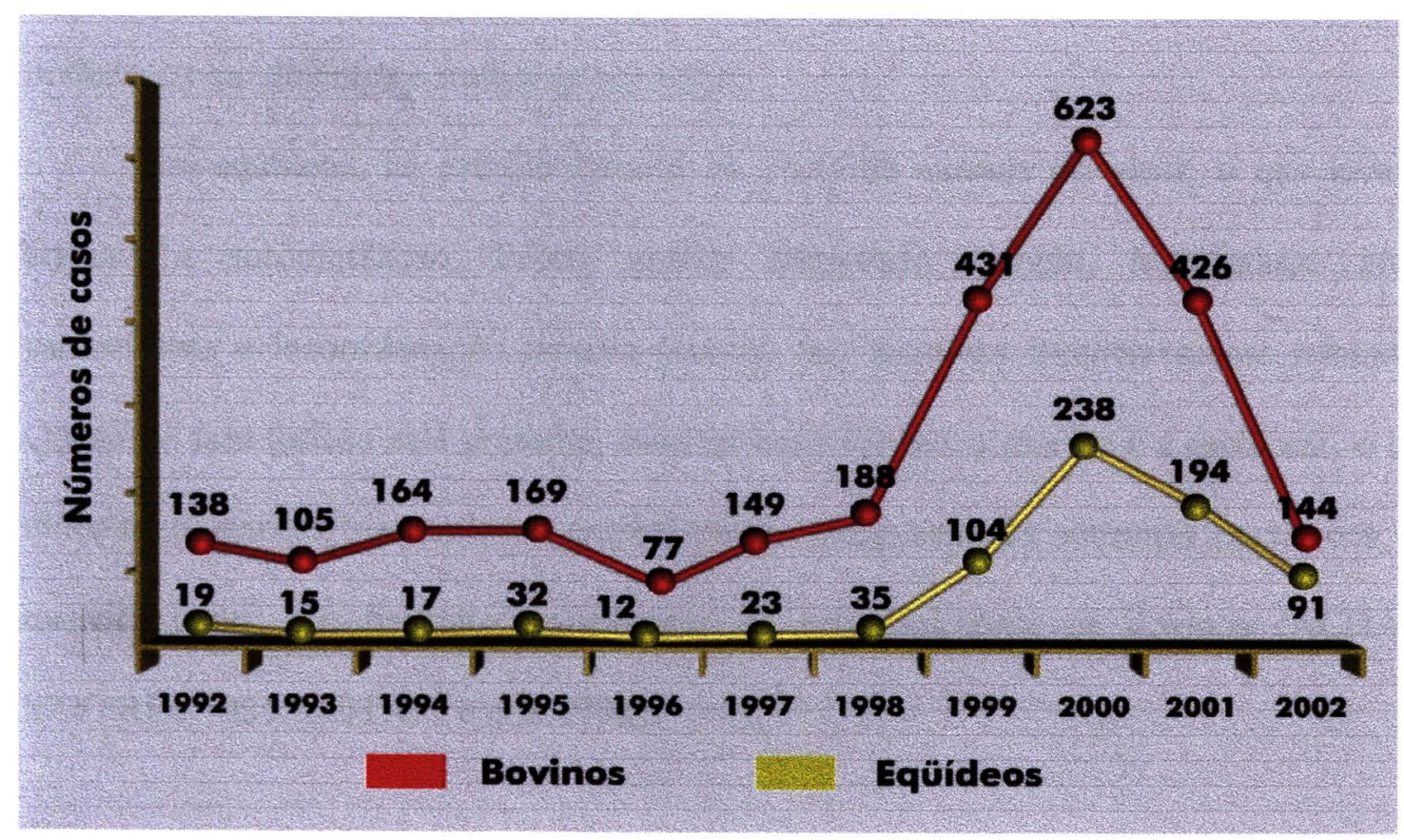

Figura 5 - Número de casos de raiva em herbívoros no Estado de São Paulo 1992-2002. FONTE: CPCR/Instituto Pasteur 
Os bovinos infectados pelo vírus da raiva isolam-se dos demais do rebanho; alguns podem apresentar midríase e pêlos arrepiados, enquanto outros podem apresentar sialorréia. Pode haver movimentos anormais dos membros posteriores e corrimento nasal catarral. O local da mordedura do morcego hematófago pode apresentar uma maior sensibilidade, fazendo com que o animal esfregue a região afetada, causando ulcerações. Inquietude, tremores musculares e aumento da libido também são relatados, porém, são raros os acessos de fúria. Após 2 a 3 dias dos primeiros sintomas, observam-se incoordenação e contrações tônico-clônicas da musculatura do pescoço, tronco e extremidades. Há dificuldade na deglutição e o animal apresenta aparência de engasgo. O período da doença é, geralmente, de 4 a 7 dias (BAER 1991).

Na raiva transmitida por cães, geralmente há sinais de hiperexcitação, antes do aparecimento dos sintomas de paralisia, levando os animais infectados a investir contra outros, pessoas e objetos; apresentam-se muito atentos, seguindo, com os olhos e as orelhas, os movimentos e ruídos ao seu redor.

Em eqüídeos, há prurido intenso na porta de entrada do vírus, o que leva os animais à automutilação. Febre, apetite depravado, paresia, hiperestasia, andar cambaleante e incoordenação motora (ataxia) são sintomas freqüentemente relatados. Quando a fase furiosa está presente, esses animais tendem a morder e a escoicear, o que dificulta o manejo, deixando-os extremamente perigosos. Os sintomas paralíticos, de maneira geral, são bastante semelhantes ao relatados para os bovinos (ACHA e SZYFRES 1986; KOTAIT e col. 1998). 
A ataxia pode ser mais pronunciada após o envolvimento da medula e do cerebelo e pelo fato de os eqüídeos terem seu apoio em um único dedo (NIEZGODA e col. 2002).

\subsection{Diagnóstico laboratorial}

O diagnóstico laboratorial da raiva é de fundamental importância para a confirmação do caso suspeito, bem como para o diagnóstico diferencial com outras encefalites. Também pode determinar a conduta médica em relação à necessidade ou não do tratamento anti-rábico humano. É uma ferramenta importante na avaliação das medidas de controle em áreas de epizootia, e fundamental nos programas estabelecidos de vigilância epidemiológica para raiva.

As provas diagnósticas devem apresentar elevada sensibilidade e especificidade, bem como rapidez na obtenção dos resultados. É recomendada, na rotina laboratorial de diagnóstico, a utilização de duas ou mais técnicas associadas, aumentando desta maneira a confiabilidade dos resultados finais.

O encéfalo, material de eleição para o diagnóstico da raiva, é coletado rebatendo a pele e músculos da cabeça do animal, abrindo a caixa craniana e expondo o cérebro (LÉPINE e ATANASIU 1996).

As amostras para o diagnóstico devem ser encaminhadas ao laboratório por uma via rápida, em recipientes hermeticamente fechados, perfeitamente identificados e refrigerados. Este tipo de acondicionamento deve garantir a conservação do material e 
proteger pessoas e o meio ambiente durante seu transporte. É importante, também, o envio de fichas epidemiológicas devidamente preenchidas.

\subsubsection{Técnicas histológicas}

A primeira descrição de lesão em um neurônio infectado pelo vírus da raiva foi feita em 1903 por Adelchi Negri (PERL e GOOD, 1991; LÉPINE e ATANASIU 1996; SCARANI e col. 1997; IWASAKI e TOBITA 2002), ao observar inclusões no citoplasma celular. Durante muitos anos, foram utilizadas, para o diagnóstico da raiva, as técnicas histológicas, como a coloração de Sellers, Faraco, Giemsa e Mann, que consistem, basicamente, na detecção dos corpúsculos de Negri, através da utilização de corantes adequados. Tais corpúsculos possuem formas arredondadas ou ovais, cujo tamanho varia de 0,2 a $0,5 \mu \mathrm{m}$ de diâmetro e são formadas por ribonucleoproteínas das partículas virais em maturação (TIERKEL e ATANASIU 1996).

Os métodos histológicos são rápidos, práticos e de baixo custo, mas apresentam menor grau de sensibilidade que as provas utilizadas atualmente, alcançando até $80 \%$, dependendo da experiência do observador (GERMANO e col. 1977; PEIXOTO e col. 2000)

$\mathrm{Na}$ atualidade, as técnicas histológicas não vêm mais sendo utilizadas rotineiramente no diagnóstico laboratorial, visto que a Organização Mundial de Saúde recomenda a prova de imunofluorescência direta e o isolamento viral (TIERKEL e ATANASIU 1996). 


\subsubsection{Isolamento viral}

A inoculação intracerebral de suspensões suspeitas de conterem o virus da raiva em camundongos albinos-suíços, para o diagnóstico da raiva, foi preconizada por WEBSTER e DAWSON (1935).

Esta técnica apresenta um alto grau de sensibilidade, porém com resultados mais demorados, uma vez que o período de incubação do vírus de rua, em camundongos, geralmente varia de 7 a 21 dias. Os sintomas dos animais inoculados são: pêlos arrepiados, aerofobia, falta de coordenação dos membros posteriores, paralisia e prostração. No entanto, estes sinais clínicos não são suficientes para que se emita um laudo e a prova de imunofluorescência direta deve ser feita com o cérebro dos animais, para se visualizar os antígenos específicos. Mortes ocorridas antes de 48 horas não são atribuídas ao virus da raiva, pois o período de incubação é maior, sendo recomendada a observação dos animais inoculados por um periodo de $21 \mathrm{ou}$, preferencialmente, 28 dias (SUREAU 1988; SUREAU e col. 1991).

Camundongos lactentes, com 3-5 dias de idade, são mais susceptiveis ao virus rábico e podem ser utilizados como uma alternativa para melhorar o isolamento viral (NILSSON e SUGAY 1966).

Segundo KING (1996), o primeiro relato de cultivo do vírus rábico em células data de 1930. Entretanto, apenas recentemente o isolamento do vírus em células foi melhor desenvolvido. Tais estudos demonstraram que essa técnica apresenta alta sensibilidade, menor tempo para a obtenção dos resultados (72 ou 96 horas), e menor custo, pois dispensa a necessidade de manutenção de animais de laboratório. As células 
de neuroblastoma murino (NA-C1300) apresentam maior sensibilidade à infecção que outras linhagens celulares (CLARK 1978; KING 1996; WEBSTER e CASEY 1996).

\subsubsection{Imunofluorescência direta}

A técnica de imunofluorescência direta baseia-se na capacidade que os anticorpos apresentam de resistirem à ligação química com corantes fluorescentes, sem que seja alterada sua capacidade de reagir imunologicamente. $O$ emprego da microscopia de fluorescência para observação da reação antígeno-anticorpo foi baseado em trabalhos publicados por COONS e KAPLAN (1950). A aplicação desta técnica na identificação do vírus da raiva, ou dos seus antígenos, foi descrita por GOLDWASSER e KISSLING (1958), com grande vantagem sobre as técnicas histológicas.

A prova de anticorpos fluorescentes é rápida, sensivel e específica, com custo não muito elevado. Consiste em uma prova sorológica na qual, para detectar a reação antígeno-anticorpo, se utiliza um sistema revelador, chamado conjugado, que nada mais é que uma substância fluorescente, o isotiocianato de fluoresceína (fluorocromo), unido ao anticorpo. Essa reação é visualizada ao microscópio de imunofluorescência e faz uso de uma propriedade que algumas moléculas, como o isotiocianato de fluoresceína, apresentam de absorver luz de determinado comprimento de onda (luz ultravioleta) e emitir luz de comprimento de onda maior (luz verde). Os antígenos, que reagiram com o anticorpo marcado, aparecem como partículas brilhantes de cor esverdeada, com diferentes formas, geralmente ovalados ou arredondados, no citoplasma celular. A qualidade da fluorescência depende, principalmente, de um microscópio adequado e da 
qualidade do conjugado e da experiência do observador, sendo a sensibilidade desta prova de cerca de 99\% ( WEBSTER e CASEY 1988; DEAN e col. 1996).

\subsubsection{Tipificação antigênica}

WIKTOR e KOPROWSKI (1978), através da vacinação de camundongos BALB/c, obtiveram anticorpos monoclonais que foram utilizados na técnica de imunofluorescência indireta e forneceram uma excelente contribuição aos estudos epidemiológicos

Embora os métodos sorológicos que utilizavam anticorpos policlonais permitissem diferenciar o vírus da raiva dos outros Lyssavirus, só conseguiam estabelecer ligeiras diferenças entre as diversas amostras do vírus clássico da raiva. $\mathrm{O}$ método de caracterização antigênica, através da utilização de anticorpos monoclonais, permite identificar as variantes responsáveis por episódios e por casos individuais, tanto de humanos como de animais (OPAS 2000a).

Os anticorpos monoclonais permitem, também, análises antigênicas comparativas das variantes do vírus da raiva. A reatividade é determinada utilizando um painel de anticorpos monoclonais específicos para epítopos da nucleoproteína viral e é visualizada pela coloração fluorescente (OPAS 2000a). Alguns laboratórios utilizam anticorpos monoclonais direcionados aos epítopos da fosfoproteína (RAUX e col. 1997; NADIN-DAVIS e col. 2000) e outros aos epítopos da glicoproteína (HASS 1997). O painel de anticorpos monoclonais antinucleoproteina, produzido pelo "Centers for Disease Control and Prevention" (CDC), Atlanta, EUA e definido pela Organização Panamericana de Saúde, para estudo das amostras isoladas nas Américas, tem se 
mostrado adequado tanto para possibilitar a máxima diferenciação entre os vírus da raiva importantes do ponto de vista de saúde pública, como a distribuição e a transmissão entre as diferentes espécies selvagens (DIAZ e col. 1994; SMITH e col. 1986; SMITH 1988, 2002; MATTOS e col. 1996).

A caracterização das variantes tem sido muito útil também para entender a epidemiologia da raiva humana, sobretudo nas situações onde não há evidências de exposição ao vírus, como, por exemplo, em regiões onde a raiva canina está controlada.

Vários pesquisadores têm conduzido estudos epidemiológicos e ecológicos nas Américas e Caribe usando anticorpos monoclonais (WIKTOR e KOPROWSKI 1980; SMITH 1988, 1989; LARGHI e col. 1989; DIAZ e col. 1994; DELPIETRO e col. 1997; VILLA e col. 2002, FAVI e col. 2003).

Estudos antigênicos e imunogênicos realizados com amostras isoladas no Brasil, utilizando anticorpos monoclonais, foram desenvolvidos por HAYASHI e col. (1984); GERMANO e col. (1990); ROEHE e col. (1997); FAVORETTO e col. (2002).

Pesquisas com anticorpos monoclonais são, também, importantes para selecionar variantes para ensaios imunes com o objetivo de verificar a proteção conferida pelas vacinas, preparadas com vírus fixo, frente ao desafio com vírus de rua (SUREAU e col. 1983).

O uso exclusivo de anticorpos monoclonais, no entanto, apresenta certas limitações. Por exemplo, a diversidade das variantes presentes em morcegos, especialmente nos insetívoros, não é totalmente explicada com os anticorpos monoclonais existentes. A análise genômica é, evidentemente, mais adequada, pois proporciona informações detalhadas sobre a relação evolutiva dos isolados, as mudanças 
espaciais e temporais produzidas e a semelhança entre os isolados (OPAS 2000a).

\subsubsection{Análise genética}

A análise genética do vírus da raiva se realiza mediante a reação de transcrição reversa, seguida de reação em cadeia de polimerase (RT-PCR) e análise dos produtos de amplificação (TORDO 1996). SACRAMENTO e col. (1991) propuseram a técnica de RT-PCR como uma alternativa para o diagnóstico laboratorial e, comparando esta técnica com a IFD e inoculação intracerebral em camundongos, obtiveram uma concordância de $100 \%$.

O advento da RT-PCR, e de outros ensaios moleculares na década de 1980, trouxe vantagens ao diagnóstico da raiva, particularmente como teste confirmatório (TORDO 1996; NADIN-DAVIS 1999). Entretanto, quando comparado com a IFD, o beneficio do RT-PCR como teste de rotina, em muitas situações, está limitado pela necessidade de "primers" universais para todos lyssavírus, a demora em relação aos outros testes, o custo do equipamento e a necessidade de especialistas (RUPPRECHT 2002).

Resultados positivos inesperados, ou incomuns pela IFD, também podem ser confirmados rapidamente através das técnicas de biologia molecular (TRIMARCHI e SMITH 2002). Vários autores relatam a confirmação da encefalite rábica em amostras humanas e animais em estado de autólise, demonstrando a importância da biologia molecular neste diagnóstico (TRIMARCHI e SMITH 2002; DAVID e col. 2002).

SMITH e col. (1992) analisando geneticamente 87 isolados de vírus da raiva, de cães e de humanos, de vários continentes, estabeleceram relações epidemiológicas e 
históricas dos eventos estudados.

A aplicação da tipificação antigênica e genética na vigilância da raiva na América Latina e Caribe tem sido essencial para melhorar os atuais programas de controle da doença (OPAS 2000b).

SACRAMENTO e col. (1994), utilizando a técnica de RT-PCR e seqüenciamento genético para estudar amostras do Estado de São Paulo, verificaram dois biótipos: um a partir de animais de estimação (cães e gatos), bastante similar aos virus fixos CVS, PV e PM, e outro a partir de bovinos, eqüinos e quirópteros, com acentuadas diferenças quando comparadas aos vírus fixos.

O conhecimento da fonte de infeç̧ão de novos focos de raiva canina e felina (CARRIERI e col. 2001; BADILLA e col. 2003; FAVI e col. 2003; PÁEZ e col 2003) e a identificação das espécies silvestres, que mantêm os ciclos silvestres de transmissão da raiva (KOTAIT 2003), possibilitam uma melhor utilização dos recursos de saúde pública.

No Brasil, o Instituto Pasteur de São Paulo vem utilizando estas técnicas, antigênicas e genéticas, em colaboração com o $\mathrm{CDC} /$ Atlanta/EUA, que têm permitido determinar a distribuição geográfica das variantes antigênicas e genéticas do vírus da raiva, descrever novas variantes e identificar variantes conhecidas em novos hospedeiros, informações muito úteis para a vigilância epidemiológica da raiva (FAVORETTO e col. 2002; KOTAIT 2003).

Recentemente, vários outros pesquisadores têm realizado estudos genéticos com amostras isoladas no Brasil (ITO e col. 2001, 2003; SOARES e col. 2002; ROMIJN e col. 2003). 


\subsection{Tratamento profilático humano}

No Brasil, a raiva é endêmica, em grau diferenciado de acordo com a região geopolítica. A região Nordeste foi responsável por $58,80 \%$ dos casos humanos registrados de 1986 a 2001, seguida da região Norte, com 20,85\%, Sudeste com 10,80\%, Centro-Oeste $9,40 \%$ e Sul 0,15\%. Desde 1987, não há registro de casos nos estados do Sul, tendo o último caso ocorrido no Paraná, cuja fonte de infecção foi um morcego hematófago. Segundo dados do MINISTÉRIO DA SAÚDE (2002), no período de 1991 a 2001 , cães e gatos foram responsáveis pela transmissão de $80,52 \%$ dos casos de raiva humana; - os morcegos, por 10,13\%; outros animais - raposas, sagüis, gato selvagem, bovinos, eqüídeos, caititus, gambás, suínos e caprinos - transmitiram 4,94\% dos casos.

No Estado de São Paulo, no período de 1983 a 2002, foram registrados 20 casos, sendo em $15(79 \%)$ a espécie transmissora a canina; em 2 (11\%), foram morcegos não hematófagos; em 1 (5\%), não se esclareceu se foi o cão ou o morcego; em 1 (5\%), o animal agressor não foi identificado e em outro caso (5\%) o animal foi um felino, porém a variante do vírus encontrada foi de morcego hematófago (KOTAIT e col. 2002; TAKAOKA 2003).

O diagnóstico laboratorial é essencial para a eleição de estratégias e definição de tratamento do paciente, como também para o conhecimento do risco da doença na região de procedência do animal.

As Normas Internacionais de Tratamento Anti-Rábico Humano pós-exposição levam em consideração o resultado da prova de imunofluorescência direta, processada com a amostra do animal agressor e/ou suspeito, quando pertence à categoria de animal doméstico. A mesma conduta é recomendada pela Norma preconizada pelo Ministério 
da Saúde do Brasil. Considera-se que, não sendo detectado antigeno rábico do sistema nervoso destes animais suspeitos, não há possibilidade de se encontrar vírus na saliva, sendo desnecessário o tratamento anti-rábico (MINISTÉRIO DA SAÚDE 2002).

Na Norma de Tratamento Profilático Humano do Estado de São Paulo, o resultado da técnica de IFD também é decisivo para conduta de tratamento humano frente aos acidentes com animais domésticos. No entanto, em função dos resultados obtidos por PEIXOTO e col. (2000), que verificaram haver uma menor sensibilidade da técnica de IFD quando aplicada às amostras de eqüídeos, nos acidentes com estes animais, dependendo do tipo de exposição e independentemente do resultado negativo da IFD, as pessoas expostas ao risco recebem o esquema de pós-exposição (COSTA e col. 2001).

No Estado de São Paulo, os eqüídeos, além de terem importância econômica, são muito utilizados como animais de recreação em inúmeras estâncias de lazer. Face ao aumento dos casos de raiva nestes animais na última década, e a frequente manipulação destes animais por crianças e adultos, é indispensável a identificação de fragmentos nos quais a concentração de virus seja maior, possibilitando a utilização das técnicas convencionais de diagnóstico da raiva, a análise real do risco da exposição e otimizando, desta forma, o tratamento profilático humano. 


\section{OBJETIVOS}

2.1 Comparar a sensibilidade das técnicas de imunofluorescência direta e do isolamento viral em camundongos, para o diagnóstico laboratorial da raiva eqüina, transmitida naturalmente pelo morcego hematófago (Desmodus rotundus), quando aplicadas aos diferentes fragmentos do SNC (corno de Amon, córtex, cerebelo, tronco encefálico e medula);

2.2 Analisar os diferentes fragmentos do SNC para o diagnóstico laboratorial da raiva em eqüídeos, tendo como condição do animal a vacinação ou não, e a eutanásia ou o óbito natural pela doença;

2.3 Relacionar o isolamento do vírus rábico a partir de glândulas salivares com a concentração de antígeno nos diferentes fragmentos, verificada pela IFD;

2.4 Analisar o risco potencial para humanos, do manejo de eqüídeos infectados pelo vírus rábico, considerando o fragmento encaminhado ao laboratório e o resultado do diagnóstico laboratorial. 


\section{MATERIAL E MÉTODOS}

Os profissionais veterinários que atuam na Coordenadoria de Defesa Agropecuária e na Coordenadoria de Assistência Técnica Integral, ambas da Secretaria de Agricultura e Abastecimento do Estado de São Paulo, e veterinários das Secretarias Municipais de Saúde realizam coletas e remessas de amostras de SNC de herbívoros para o diagnóstico laboratorial da raiva, como uma das atividades do Programa de Controle da Raiva nestes animais. Foi elaborado um protocolo de envio de amostras do SNC, originárias de eqüídeos, com suspeita clínica de encefalite rábica, sendo que este protocolo estabeleceu o envio habitual e o atendimento de outros quesitos, imprescindíveis para o desenvolvimento da presente pesquisa.

3.1 Animais: os animais-alvo deste estudo foram 103 eqüídeos (99 eqüinos e 4 muares), provenientes de 14 municípios da região leste do Estado de São Paulo (Figura 6), dos quais $55(53,4 \%)$ foram positivos para a raiva e $48(46,6 \%)$ negativos, pelas técnicas de IFD e isolamento viral em camundongos. As amostras foram coletadas no período de outubro de 2000 a maio de 2003.

\subsubsection{Sistema Nervoso central (SNC)}

Coletaram-se, separadamente, diversos fragmentos do encéfalo - córtex (CX), hipocampo ou corno de Amon (CA), cerebelo (CB), tronco encefálico (TE), e de 
medula cervical (MD), após o óbito natural do animal ou, estando em fase terminal da doença, após realização da eutanásia através da injeção de acepromazina associado à trietiliodeto de galamina.

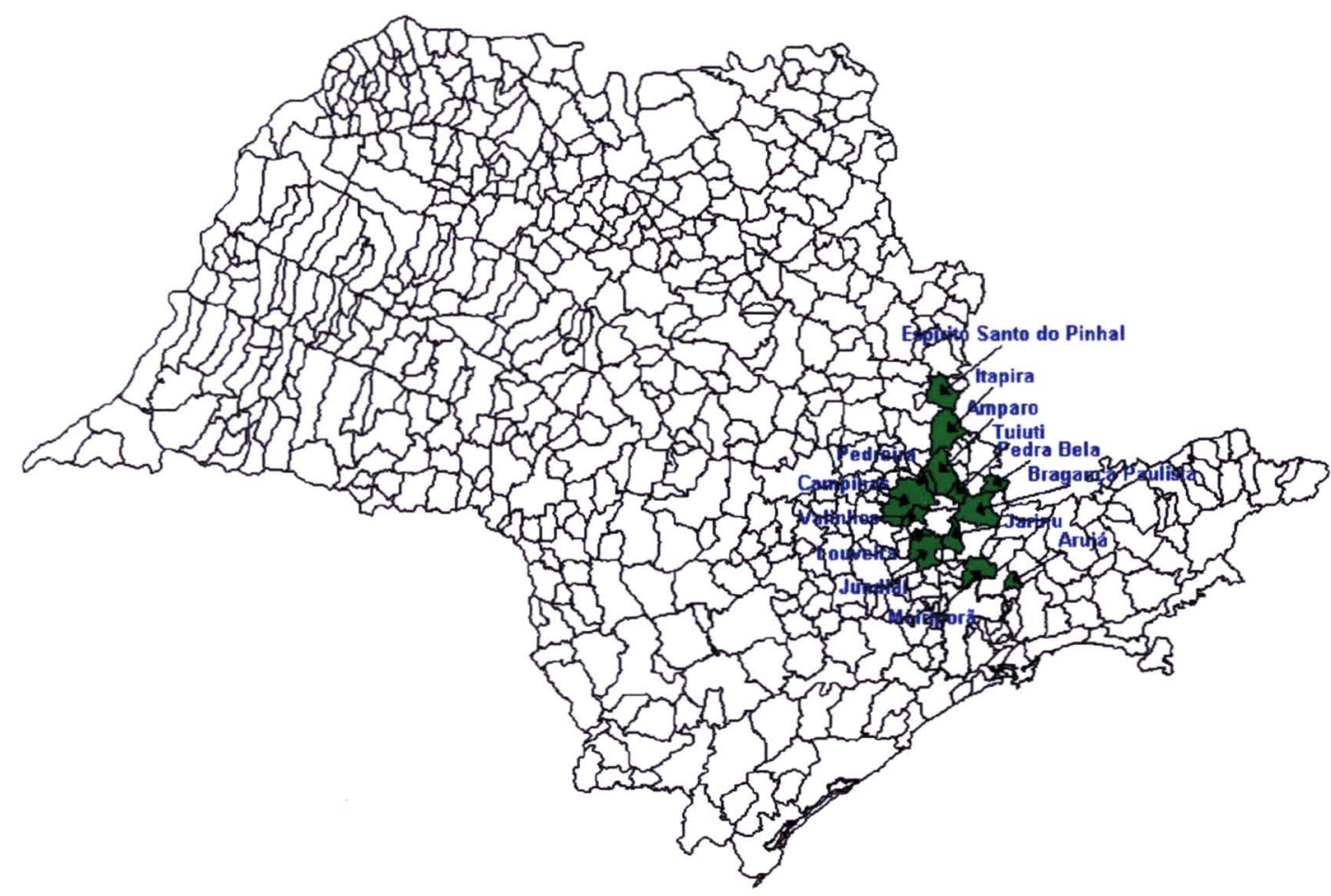

Figura 6 - Municípios de procedência das amostras de eqüídeos analisadas, São Paulo, 2000-2003.

FONTE: CPCR/Instituto Pasteur

Fragmentos de cada uma destas porções foram acondicionados em potes individualizados e encaminhados ao laboratório de diagnóstico do Instituto Pasteur, conservados em isopor com gelo, ou congelados. Foram processados fragmentos do SNC dos 103 eqüídeos. 


\subsubsection{Glândulas salivares}

Sempre que possível, foi feita a coleta de 1 a três glândulas salivares (parótida, submandibular ou sublingual) destes animais, sendo estas enviadas para o mesmo laboratório, conservadas em isopor com gelo, ou congeladas. Foram processadas glândulas salivares de 87 eqüídeos totalizando 171 glândulas.

Os quadros de 1 e 2 apresentam o perfil da população estudada, eqüídeos positivos para raiva por um ou dois métodos de diagnóstico, bem como os fragmentos e as glândulas salivares coletadas.

QUADRO 1 -Eqüídeos positivos para raiva, de acordo com os fragmentos de sistema nervosos central e glândulas salivares coletadas. São Paulo, 2000 -2003.

\begin{tabular}{lcccc}
\hline \multirow{2}{*}{$\begin{array}{l}\text { Glândula } \\
\text { Salivar }\end{array}$} & \multicolumn{2}{c}{ Número de fragmentos do SNC } & Total \\
\cline { 2 - 4 } & cinco & quatro & três & \\
\hline P; SM; SL & 5 & 3 & 0 & 8 \\
P; SM & 18 & 8 & 4 & 30 \\
P; SL & 1 & 0 & 0 & 1 \\
P & 6 & 1 & 2 & 9 \\
SM & 2 & 0 & 0 & 2 \\
NC & 3 & 2 & 0 & 5 \\
\hline Total & 35 & 14 & 6 & 55 \\
\hline $\begin{array}{l}\text { P: glândula parótida; SM: submandibular e SL: sublingual } \\
\text { SNC: sistema nervosos central }\end{array}$ & & & \\
NC: não coletadas & & & &
\end{tabular}


Quadro 2 - Eqüídeos positivos para a raiva, por número de fragmentos do $\mathrm{SNC}$ e glândulas salivares analisados e número de pessoas expostas. São Paulo, 2000-2003.

\begin{tabular}{|c|c|c|c|c|c|c|c|c|c|c|c|c|c|}
\hline \multirow[t]{2}{*}{ Animal } & \multicolumn{5}{|c|}{$\begin{array}{l}\text { Fragmento } \\
\text { SNC }\end{array}$} & \multicolumn{3}{|c|}{$\begin{array}{c}\text { Glândula } \\
\text { salivar }\end{array}$} & \multirow[t]{2}{*}{$\begin{array}{c}\text { Tipo de } \\
\text { Óbito }\end{array}$} & \multirow[t]{2}{*}{$\begin{array}{l}\text { Vaci- } \\
\text { nação }\end{array}$} & \multirow[t]{2}{*}{$\begin{array}{c}\text { Idade } \\
\text { (anos/dias) }\end{array}$} & \multirow{2}{*}{$\begin{array}{c}\text { Perfodo } \\
\text { de } \\
\text { doença } \\
\text { (dias) }\end{array}$} & \multirow[t]{2}{*}{$\begin{array}{l}\text { Número de } \\
\text { pessoas } \\
\text { expostas }\end{array}$} \\
\hline & $\mathrm{CA}$ & $\mathrm{CX}$ & $\mathrm{CB}$ & TE & MD & PA & SM & SL & & & & & \\
\hline 1 & $x$ & $\mathrm{x}$ & $x$ & $x$ & $x$ & $\mathbf{x}$ & $\mathrm{x}$ & $\bullet$ & natural & $\operatorname{sim}$ & - & - & 1 \\
\hline 2 & $\mathrm{x}$ & $x$ & $x$ & $\mathrm{x}$ & $\mathrm{x}$ & $\mathbf{x}$ & $x$ & $\bullet$ & eutanásia & sim & - & - & 1 \\
\hline 3 & $\mathrm{x}$ & $\mathrm{x}$ & $x$ & $\mathrm{x}$ & $\mathrm{x}$ & $x$ & $\mathrm{x}$ & $\bullet$ & natural & $\operatorname{sim}$ & - & 3 & 1 \\
\hline 4 & $\mathrm{x}$ & $x$ & $\mathbf{x}$ & $\mathrm{x}$ & $x$ & $\bullet$ & $\mathrm{X}$ & $\bullet$ & natural & sim & - & - & 2 \\
\hline 5 & $x$ & $x$ & $x$ & $\mathrm{x}$ & $x$ & $\mathbf{x}$ & $x$ & $\mathrm{x}$ & natural & $\operatorname{sim}$ & - & - & 2 \\
\hline 6 & $x$ & $x$ & $\mathbf{x}$ & $\mathbf{x}$ & $\mathbf{x}$ & $\mathbf{x}$ & $\mathbf{x}$ & $\bullet$ & natural & $\operatorname{sim}$ & 4 & & não \\
\hline 7 & $\mathrm{x}$ & $\mathrm{x}$ & $x$ & $x$ & $\mathrm{x}$ & $\mathbf{x}$ & $\mathbf{x}$ & - & eutanásia & não & 2 & 3 & 1 \\
\hline 8 & $\mathrm{x}$ & $x$ & $\mathbf{x}$ & $x$ & $x$ & $\mathbf{x}$ & $\bullet$ & $\mathbf{x}$ & eutanásia & - & 2,5 & - & 15 \\
\hline 9 & $x$ & $x$ & $x$ & $x$ & $x$ & $\mathbf{x}$ & $x$ & $\bullet$ & natural & $\operatorname{sim}$ & 20 & 3 & não \\
\hline 10 & $\mathbf{x}$ & $\mathbf{x}$ & $\mathbf{x}$ & $\mathbf{x}$ & $\mathbf{x}$ & $\mathbf{x}$ & $x$ & $\mathbf{x}$ & natural & - & - & - & 15 \\
\hline 11 & $\mathbf{x}$ & $\mathbf{x}$ & $x$ & $\mathrm{x}$ & $\mathrm{x}$ & $\mathbf{x}$ & $\mathrm{x}$ & $\mathbf{x}$ & natural & não & - & - & 4 \\
\hline 12 & $\mathrm{x}$ & $\mathrm{x}$ & $x$ & $\mathbf{x}$ & $\mathrm{x}$ & $\mathbf{x}$ & $\mathrm{x}$ & $\mathbf{x}$ & natural & sim & - & - & não \\
\hline 13 & $\mathbf{x}$ & $x$ & $x$ & $x$ & $x$ & $\mathbf{x}$ & $\mathrm{x}$ & $\mathbf{x}$ & eutanásia & - & 1,5 & - & não \\
\hline 14 & $\mathbf{x}$ & $\mathbf{x}$ & $x$ & $x$ & $\mathbf{x}$ & $\mathbf{x}$ & $\bullet$ & $\bullet$ & eutanásia & sim & 4 & - & - \\
\hline 15 & $\mathbf{x}$ & $\mathbf{x}$ & $x$ & $\mathbf{x}$ & $x$ & $\mathbf{x}$ & - & - & natural & $\operatorname{sim}$ & 20 & - & - \\
\hline 16 & $\mathrm{x}$ & $\mathrm{x}$ & $x$ & $x$ & $x$ & $\mathbf{x}$ & $\mathrm{x}$ & $\bullet$ & eutanásia & não & 20 & 6 & - \\
\hline 17 & $\mathrm{x}$ & $\mathrm{x}$ & $\mathbf{x}$ & $x$ & $x$ & $x$ & $x$ & $\bullet$ & eutanásia & não & 1 & - & - \\
\hline 18 & $\mathbf{x}$ & $\mathrm{x}$ & $\mathbf{x}$ & $\mathbf{x}$ & $\mathbf{x}$ & $\bullet$ & $\mathbf{x}$ & $\bullet$ & eutanásia & não & 9 & - & - \\
\hline 19 & $\mathrm{x}$ & $x$ & $x$ & $\mathrm{x}$ & $\mathrm{x}$ & $\mathbf{x}$ & $\bullet$ & $\bullet$ & eutanásia & não & 20 & - & - \\
\hline 20 & $\mathrm{x}$ & $\mathbf{x}$ & $\mathbf{x}$ & $\mathbf{x}$ & $\mathbf{x}$ & $\mathbf{x}$ & $\bullet$ & $\bullet$ & eutanásia & não & 8 & - & - \\
\hline $21^{*}$ & $x$ & $\bar{x}$ & $\mathrm{x}$ & $\mathrm{x}$ & $\mathrm{x}$ & $\mathrm{x}$ & $\bullet$ & $\bullet$ & eutanásia & não & 90dias & - & - \\
\hline 22 & $\mathrm{x}$ & $x$ & $\mathrm{x}$ & $x$ & $x$ & $\mathrm{x}$ & $\mathbf{x}$ & $\bullet$ & eutanásia & não & 3 & 4 & - \\
\hline 23 & $\mathrm{x}$ & $\mathrm{x}$ & $\mathrm{x}$ & $\mathrm{x}$ & $\mathrm{x}$ & $\mathbf{x}$ & $\mathbf{x}$ & $\bullet$ & natural & $\operatorname{sim}$ & 8 & 3 & - \\
\hline 24 & $\mathrm{x}$ & $\mathbf{x}$ & $x$ & $\mathbf{x}$ & $\mathbf{x}$ & $\mathbf{x}$ & $\bullet$ & $\bullet$ & eutanásia & não & 40 dias & - & - \\
\hline 25 & $\mathrm{x}$ & $x$ & $x$ & $\mathrm{x}$ & $\mathbf{x}$ & $\mathbf{x}$ & $\mathbf{x}$ & $\bullet$ & eutanásia & não & 7 & 3 & - \\
\hline
\end{tabular}

CA:como de Amon, CX:córtex, CB:cerebelo, TE:tronco encefálico e MD:medula, PA -glândula parótida, SM-glândula submandibular SL: glândula sublingual

$\mathrm{X}$ : coletado

$\bullet:$ não coletado

$-:$ dado nåo disponivel

*: muar 
Quadro 2 - Eqüídeos positivos para a raiva, por número de fragmentos do $\mathrm{SNC}$ e glândulas salivares analisados e número de pessoas expostas. São Paulo, 2000-2003.

\begin{tabular}{|c|c|c|c|c|c|c|c|c|c|c|c|c|c|}
\hline \multirow{2}{*}{$\begin{array}{l}\text { Número } \\
\text { do } \\
\text { animal }\end{array}$} & \multicolumn{5}{|c|}{$\begin{array}{c}\text { Fragmento } \\
\text { SNC }\end{array}$} & \multicolumn{3}{|c|}{$\begin{array}{l}\text { Glândula } \\
\text { salivar }\end{array}$} & \multirow[t]{2}{*}{ Óbito } & \multirow[t]{2}{*}{$\begin{array}{l}\text { Vaci- } \\
\text { nação }\end{array}$} & \multirow[t]{2}{*}{$\begin{array}{c}\text { Idade } \\
\text { (anos/dias) }\end{array}$} & \multirow[t]{2}{*}{$\begin{array}{c}\text { Perfodo } \\
\text { de } \\
\text { doença } \\
\text { (dias) }\end{array}$} & \multirow[t]{2}{*}{$\begin{array}{c}\text { Número de } \\
\text { pessoas } \\
\text { expostas }\end{array}$} \\
\hline & $\mathrm{CA}$ & $\mathrm{CX}$ & CB & TE & MD & PA & SM & $\mathrm{SL}$ & & & & & \\
\hline $26^{*}$ & $\mathrm{x}$ & $\mathbf{x}$ & $\mathrm{x}$ & $\mathrm{x}$ & $\mathrm{x}$ & $\mathbf{x}$ & $\mathrm{x}$ & $\bullet$ & natural & não & 10 & 4 & - \\
\hline 27 & $\mathrm{x}$ & $x$ & $\mathrm{x}$ & $x$ & $\mathrm{x}$ & $\mathbf{x}$ & $\mathbf{x}$ & $\bullet$ & eutanásia & $\operatorname{sim}$ & 1 & 3 & - \\
\hline 28 & $x$ & $x$ & $\mathrm{x}$ & $x$ & $\mathrm{x}$ & $\mathbf{x}$ & $x$ & $\bullet$ & natural & sim & 9 & 2 & não \\
\hline 29 & $\mathrm{x}$ & $x$ & $x$ & $x$ & $x$ & $\mathbf{x}$ & $\mathrm{x}$ & $\bullet$ & eutanásia & não & - & 7 & - \\
\hline $30^{*}$ & $\mathrm{x}$ & $\mathrm{x}$ & $\mathrm{x}$ & $\mathrm{x}$ & $\mathrm{x}$ & $\mathbf{x}$ & $\mathbf{x}$ & $\bullet$ & natural & $\operatorname{sim}$ & 5 & - & 1 \\
\hline 31 & $\bullet$ & $x$ & $\mathbf{x}$ & $\mathbf{x}$ & $\mathrm{x}$ & $\mathrm{x}$ & $\mathrm{x}$ & $\bullet$ & natural & não & - & - & 5 \\
\hline 32 & $\mathbf{x}$ & $\bullet$ & $\mathrm{x}$ & $x$ & $\bullet$ & $\mathbf{x}$ & $\mathbf{x}$ & $\bullet$ & natural & $\operatorname{sim}$ & - & - & 1 \\
\hline 33 & $\mathrm{x}$ & $\bullet$ & $x$ & $\mathbf{x}$ & $\bullet$ & $\mathbf{x}$ & - & $\bullet$ & eutanásia & não & 3 & 3 & - \\
\hline 34 & $\mathrm{x}$ & $\mathbf{x}$ & $\mathrm{x}$ & $\bullet$ & $\mathrm{x}$ & $\mathbf{x}$ & $\mathbf{x}$ & $\bullet$ & eutanásia & $\operatorname{sim}$ & - & 15 & 10 \\
\hline 35 & $\mathrm{x}$ & $x$ & $\mathrm{x}$ & $\bullet$ & $x$ & $\mathbf{x}$ & $\mathbf{x}$ & $\bullet$ & natural & $\operatorname{sim}$ & - & - & 8 \\
\hline 36 & $\mathbf{x}$ & $\mathrm{x}$ & $\bullet$ & $\mathbf{x}$ & $\mathrm{x}$ & $\mathrm{x}$ & $\mathbf{x}$ & $\mathbf{x}$ & natural & $\operatorname{sim}$ & - & - & 11 \\
\hline 37 & $\bullet$ & $\mathrm{x}$ & $\mathrm{x}$ & $\bullet$ & $\mathrm{x}$ & $\mathbf{x}$ & $\mathbf{x}$ & $\bullet$ & natural & - & - & - & 2 \\
\hline $38^{*}$ & $\bullet$ & $\mathrm{x}$ & $\mathrm{x}$ & $\mathrm{x}$ & $\mathrm{x}$ & $x$ & $\mathbf{x}$ & $\mathbf{x}$ & natural & $\operatorname{sim}$ & - & - & 1 \\
\hline 39 & $\mathbf{x}$ & $\mathbf{x}$ & $\mathbf{x}$ & $\mathbf{x}$ & - & $x$ & $\mathrm{x}$ & $\mathbf{x}$ & natural & - & - & - & 3 \\
\hline 40 & $x$ & $\mathrm{x}$ & $\mathrm{x}$ & $\mathrm{x}$ & $\bullet$ & $x$ & $\mathbf{x}$ & $\bullet$ & natural & $\operatorname{sim}$ & 3 & - & 2 \\
\hline 41 & $\bullet$ & $x$ & $\mathrm{x}$ & $\bullet$ & $x$ & $\mathrm{x}$ & $\mathrm{x}$ & - & eutanásia & não & - & 30 & - \\
\hline 42 & $\mathrm{x}$ & $\mathrm{x}$ & $\mathrm{x}$ & $\bullet$ & $\bullet$ & $x$ & $\mathbf{x}$ & $\bullet$ & eutanásia & não & 15 & - & - \\
\hline 43 & $\mathrm{x}$ & $\mathrm{x}$ & $\mathrm{x}$ & $\mathrm{x}$ & $\bullet$ & $\mathbf{x}$ & $\mathbf{x}$ & - & natural & não & 3 & 2 & não \\
\hline 44 & $\bullet$ & $\mathrm{x}$ & $\mathrm{x}$ & $\mathrm{x}$ & $\mathrm{x}$ & $\mathbf{x}$ & $\mathbf{x}$ & $\bullet$ & natural & não & 5 & 7 & não \\
\hline 45 & $\mathrm{x}$ & $\mathrm{x}$ & $\mathbf{x}$ & $\mathrm{x}$ & & $\mathbf{x}$ & $\mathbf{x}$ & - & natural & não & 7 & - & - \\
\hline 46 & $\mathrm{x}$ & - & $\mathrm{x}$ & $\mathrm{x}$ & $\mathrm{x}$ & $x$ & $\bullet$ & $\bullet$ & eutanásia & não & 2 & - & - \\
\hline 47 & $\bullet$ & $\mathrm{x}$ & $\mathrm{x}$ & $x$ & $\mathrm{x}$ & $\mathbf{x}$ & $\mathbf{x}$ & $\bullet$ & natural & não & 4 & 5 & - \\
\hline 48 & $\mathrm{x}$ & $\mathbf{x}$ & $\mathbf{x}$ & $\mathrm{x}$ & $\mathrm{x}$ & $\mathbf{x}$ & $\mathbf{x}$ & $\bullet$ & natural & $\operatorname{sim}$ & 17 & 7 & não \\
\hline 49 & $\mathbf{x}$ & $\mathrm{x}$ & $\mathrm{x}$ & $\mathrm{x}$ & $x$ & $\mathbf{x}$ & $x$ & $\bullet$ & natural & não & - & 5 & 8 \\
\hline
\end{tabular}

CA:corno de Amon, CX:cóntex, CB:cerebelo, TE:tronco encefálico e MD:medula, PA -glândula parótida, SM - glândula submandibular SL: glândula sublingual

$\mathrm{x}$ : coletado

-: não coletado

$\because$ dado nåo disponivel

*: muar 
Quadro 2 - Eqüídeos positivos para a raiva, por número de fragmentos do $\mathrm{SNC}$ e glândulas salivares analisados e número de pessoas expostas. São Paulo, 2000-2003

\begin{tabular}{|c|c|c|c|c|c|c|c|c|c|c|c|c|c|}
\hline \multirow{2}{*}{$\begin{array}{l}\text { Número } \\
\text { do } \\
\text { animal }\end{array}$} & \multicolumn{5}{|c|}{$\begin{array}{c}\text { Fragmento } \\
\text { SNC }\end{array}$} & \multicolumn{3}{|c|}{$\begin{array}{l}\text { Glândula } \\
\text { salivar }\end{array}$} & \multirow[t]{2}{*}{$\begin{array}{c}\text { Tipo de } \\
\text { obito }\end{array}$} & \multirow[t]{2}{*}{$\begin{array}{l}\text { Vaci- } \\
\text { nação }\end{array}$} & \multirow[t]{2}{*}{$\begin{array}{c}\text { Idade } \\
\text { (anos/dias) }\end{array}$} & \multirow[t]{2}{*}{$\begin{array}{c}\text { Periodo } \\
\text { de } \\
\text { doença } \\
\text { (dias) }\end{array}$} & \multirow[t]{2}{*}{$\begin{array}{l}\text { Número de } \\
\text { pessoas } \\
\text { expostas }\end{array}$} \\
\hline & $\mathrm{CA}$ & $\mathrm{CX}$ & CB & $\mathrm{TE}$ & MD & $\mathrm{PA}$ & SM & $\mathrm{SL}$ & & & & & \\
\hline 50 & $\bullet$ & $\mathrm{x}$ & $\mathrm{x}$ & $\mathrm{x}$ & $\bullet$ & $\mathbf{x}$ & $\bullet$ & $\bullet$ & eutanásia & $\operatorname{sim}$ & 13 & - & 1 \\
\hline 51 & $x$ & $\bar{x}$ & $x$ & $x$ & $x$ & $\bullet$ & $\bullet$ & $\bullet$ & natural & $\operatorname{sim}$ & - & - & 6 \\
\hline 52 & $\mathrm{x}$ & $x$ & $x$ & $x$ & $x$ & $\bullet$ & $\bullet$ & $\bullet$ & natural & $\operatorname{sim}$ & - & 4 & não \\
\hline 53 & $\mathrm{x}$ & $x$ & $x$ & $x$ & $x$ & $\bullet$ & $\bullet$ & $\bullet$ & eutanásia & $\operatorname{sim}$ & - & - & não \\
\hline 54 & $\bullet$ & $x$ & $\mathrm{x}$ & $\mathrm{x}$ & $x$ & $\bullet$ & $\bullet$ & - & eutanásia & $\operatorname{sim}$ & 15 & 4 & - \\
\hline 55 & $x$ & $\bullet$ & $x$ & $x$ & $x$ & - & $\bullet$ & - & - & não & 2 & - & - \\
\hline
\end{tabular}

CA:corno de Amon, CX:córtex, CB:cerebelo, TE:tronco encefálico e MD:medula, PA-glândula parótida, SM-glândula submandibular

SL: glândula sublingual

$\mathrm{x}$ : coletado

$\bullet:$ não coletado

$\therefore$ dado não disponivel

*: muar

\subsection{Técnicas utilizadas no diagnóstico laboratorial para raiva}

\subsubsection{Imunofluorescência direta (IFD)}

Para cada fragmento pesquisado ( $\mathrm{CA}, \mathrm{CX}, \mathrm{CB}, \mathrm{TE}$ e $\mathrm{MD})$, foram preparados decalques em 5 lâminas e estas fixadas em acetona PA, por 45 minutos, a $-20^{\circ} \mathrm{C}$. Destas, três lâminas foram submetidas à técnica de IFD, utilizando conjugado anti-rábico antinucleocapsídeo $\left(\mathrm{SANOFI}^{\circledR}\right)$, marcado com isotiocianato de fluoresceína. Sempre que uma das lâminas mostrou um decalque inadequado, utilizou-se outra lâmina. A técnica 
realizada foi a recomendada pela OMS, de acordo com DEAN e col. (1996). Efetuou-se a leitura das lâminas preparadas em microscópio de imunofluorescência LEICA DMBL (lâmpada de mercúrio de 50W), segundo uma avaliação quali-quantitativa, levando-se em consideração a concentração de antígeno viral, na forma de corpúsculos de inclusão, por campo. Foram estabelecidas seis classes, sendo: classe 0 , a ausência total de antígeno; classe 1, quando a presença do antígeno em todo campo pesquisado era escasso, verificando-se de 1 a 3 pequenas inclusões; classe 2 , ou um sinal positivo $(+)$, quando na lâmina observada foram verificadas áreas negativas e escassa presença de antígeno; classe 3 , ou dois sinais $(++)$, quando a distribuição de antígeno na lâmina apresentou-se de forma homogênea, e a presença de inclusões bem características, mas ainda com áreas negativas; classe 4 , ou três sinais $(+++)$, para lâminas que apresentavam distribuição das inclusões de forma homogênea, não havendo áreas negativas e classe 5 , ou quatro sinais $(++++)$, para lâminas onde à leitura, além do número incontável de inclusões, detectou-se a presença de poeira antigênica.

\subsubsection{Isolamento viral em camundongos (IVC)}

Foram utilizados camundongos albinos suiços, criados no Biotério do Instituto Pasteur, com 21 dias de idade. Todos animais foram pesados, sendo inoculados aqueles que apresentaram peso entre 12 a 14 gramas. $O$ preparo da suspensão e a inoculação foram realizados de acordo com o preconizado por KOPROWSKI (1996). Para cada fragmento em estudo, preparou-se uma suspensão a $20 \%$, sendo inoculados sete camundongos por via intracerebral, e para a suspensão de glândulas salivares inocularam-se 10 camundongos. A observação dos animais inoculados foi realizada 
diariamente, por um período de 30 dias. Dos animais que morreram durante o período de observação, foi coletado o SNC e submetido à técnica de IFD, visando a confirmação da presença do antígeno rábico.

\subsubsection{Tipificação antigênica}

Para identificação da fonte de infecção dos casos de raiva dos eqüídeos - raiva transmitida pelo morcego hematófago - foi realizada a técnica de imunofluorescência indireta (IFI), utilizando um painel de oito anticorpos monoclonais, cedido pelo "Centers for Disease Control and Prevention" (CDC) de Atlanta-EUA. A aplicação da técnica seguiu o preconizado por DIAZ e col. (1994), usando em decalques de SNC de camundongos coletados na fase de paralisia, após inoculação com as amostras em estudo.

\subsection{Tratamento estatístico dos dados}

Para as análises estatísticas utilizadas no presente estudo - Chi Quadrado e a análise de variância de um e dois fatores - One-Way ANOVA e Two Way ANOVA (SOKAL e ROHLF 1995), foram considerados apenas os eqüídeos dos quais foram coletados os cinco fragmentos: $\mathrm{CA}, \mathrm{CX}, \mathrm{CB}, \mathrm{TE}$ e $\mathrm{MD}$, e as informações relativas ao histórico de vacinação e tipo de óbito.

\subsubsection{Teste do Chi-Quadrado}

Os testes descritos a seguir foram utilizados para cumprimento de parte dos objetivos levantados neste estudo, no que diz respeito à verificação da existência de 
diferenças entre as concentrações de antígeno viral, analisadas através do teste de IFD, em distintos fragmentos do SNC de eqüídeos. Contudo, os valores obtidos para estas concentrações de antígenos virais nos fragmentos do SNC têm caráter qualitativo ou quali-quantitativo, pois referem-se à diferentes classes de valores pré-estabelecidos, determinados de acordo com uma menor ou maior concentração de antígenos virais, na forma de inclusões, em três lâminas analisadas.

Deste modo, elaborou-se uma planilha de contingência contendo o número de observações verificados para os valores das classes definidas a priori no item 3.2.1 (Material e Métodos), e aplicou-se o teste de Chi-Quadrado (DANIEL 1995; ZAR 1999) em amostras de 35 eqüídeos dos quais foram coletados os cinco fragmentos do SNC. O termo contingência refere-se às qualidades ou aos estados que têm estreita relação entre si (MILTON 1992).

Para verificar a influência da vacinação sobre a interpretação dos resultados acerca da concentração de antígeno viral nos diferentes fragmentos do SNC de eqüídeos, realizou-se o teste de Chi-quadrado a fim de verificar a existência de independência entre fragmentos diagnósticos ( $\mathrm{CA}, \mathrm{CX}, \mathrm{CB}, \mathrm{TE} \mathrm{E} \mathrm{MD}) \mathrm{e}$ as seis classes pré determinadas de concentração de antígeno viral $(0-5)$. Considerou-se, portanto, se o animal do qual foram coletados os fragmentos, havia ou não sido vacinado anteriormente ao aparecimento dos sintomas da raiva (variável "vacinação", com dois estados, sendo estes a efetuação ou não da vacinação). As análises foram conduzidas para um total de 32 animais. A hipótese nula geral $\left(\mathrm{H}_{0}\right)$ é a de que não existe diferença nas concentrações virais de fragmentos distintos do SNC, provenientes de animais 
vacinados ou não vacinados, ou seja, as freqüências relativas de concentração do antígeno viral são as mesmas, independentemente do fragmento usado no diagnóstico e se o animal havia sido vacinado. Por conseqüência, a hipótese alternativa $\left(\mathrm{H}_{\mathrm{A}}\right)$ levantada aqui, é a de que existem diferenças nas concentrações de antígeno viral de fragmentos distintos do SNC, provenientes de animais vacinados ou não vacinados: as freqüências relativas de incidência do vírus não são as mesmas e estas dependem do fragmento usado no diagnóstico e também se o animal havia ou não sido vacinado.

Em outra análise, a fim de verificar a influência do tipo de óbito sobre a interpretação dos resultados acerca da concentração de antígeno viral nos diferentes fragmentos do SNC de eqüídeos, também foi utilizado o teste de Chi-Quadrado para verificar a existência de independência entre fragmentos diagnósticos $(\mathrm{CA}, \mathrm{CX}, \mathrm{CB}, \mathrm{TE}$ e MD) e as seis classes pré-determinadas de concentração de vírus $(0-5)$, considerando se o animal do qual foram coletados os fragmentos morreu naturalmente (morte espontânea) ou sofreu eutanásia após o aparecimento dos sintomas da raiva (variável “óbito", com dois estados: morte natural ou eutanásia).

Tais análises foram conduzidas para um total de 35 animais, utilizando-se o teste de Chi-Quadrado para independência entre variáveis. A hipótese nula geral $\left(\mathrm{H}_{0}\right)$ das análises que seguem adiante é a de que não existe diferença nas concentrações virais de fragmentos distintos do $\mathrm{SNC}$, provenientes de animais que sofreram eutanásia ou que tenham morrido naturalmente, ou seja, as freqüências relativas de concentração do antígeno viral são as mesmas, independentemente do fragmento usado no diagnóstico e se o animal morrera através de eutanásia. Conseqüentemente, a hipótese alternativa $\left(H_{A}\right)$ 
é a da existência de diferenças nas concentrações virais de fragmentos distintos do SNC, provenientes de animais que sofreram eutanásia. $\mathrm{O}$ nível de significância adotado em todos os testes foi de $5 \%(\alpha=0,05)$.

As classes de concentração de antígeno viral utilizadas nestas análises foram aquelas que se apresentaram como as mais elevadas, após a leitura das três lâminas em imunofluorescência direta. A razão para tal escolha foi baseada em testes previamente realizados, nas quais ficou evidente haver diferenças entre a utilização de classes mais baixas ou as mais altas para a realização do diagnóstico.

\subsubsection{Análise de variância - ANOVA One Way}

Seguindo a linha de raciocínio dos testes anteriores, para verificar a existência de possiveis diferenças entre a mortalidade de camundongos inoculados com suspensões preparadas a partir de diferentes fragmentos do SNC de eqüídeos, recorreu-se à análise de variância de um fator - One Way ANOVA(SOKAL e ROHLF 1995). O experimento foi baseado no isolamento viral para realização do diagnóstico da raiva, de modo que camundongos albinos suíços foram inoculados com suspensões preparadas a partir de cinco fragmentos do SNC de 33 eqüídeos.

Em termos de aplicação da ANOVA, a hipótese nula é que as taxas médias de mortalidade obtidas com a inoculação dos diferentes fragmentos devem ser iguais $\left(\mathrm{H}_{0}\right.$ : $\left.\mu_{\mathrm{CA}}=\mu_{\mathrm{CX}}=\mu_{\mathrm{CB}}=\mu_{\mathrm{TE}}=\mu_{\mathrm{MD}}\right)$, enquanto que, consequientemente, a hipótese alternativa implica que existam diferenças entre as médias $\left(\mathrm{H}_{A}: \mu_{\mathrm{CA}} \neq \mu_{\mathrm{CX}} \neq \mu_{\mathrm{CB}} \neq \mu_{\mathrm{TE}} \neq \mu_{\mathrm{MD}}\right)$. Em outras palavras, fragmentos diferentes do sistema nervoso central apresentam taxas 
distintas de mortalidade em camundongo pelo vírus da raiva. Para a realização da análise, foi utilizado o programa Statistica 5.1 (STATSOFT INCORPORATION 1997).

\subsubsection{Análise de variância - ANOVA Two Way}

Em uma outra abordagem, a fim de verificar a existência de possíveis diferenças entre a de mortalidade em camundongos causada pelo vírus da raiva, em fragmentos distintos do SNC de eqüídeos vacinados e não vacinados, recorreu-se à análise de variância de dois fatores (Two-Way ANOVA; SOKAL e ROHLF 1995), considerandose como primeiro fator da análise a presença ou ausência de vacina e, como segundo fator, os fragmentos em si.

O experimento foi baseado na prova de isolamento viral em camundongos para 30 eqüídeos que apresentaram resultados referentes aos cinco fragmentos e histórico de vacinação. Obtiveram-se, então, as taxas de mortalidade dos camundongos para cada um dos fragmentos, e estes valores foram utilizados na ANOVA. A hipótese nula a ser testada nesta nova análise é que as médias de mortalidade entre fragmentos do SNC de animais vacinados e não vacinados devem ser iguais $\left(\mathrm{H}_{0}: \mu_{\mathrm{CAv}}=\mu_{\mathrm{CAnv}}=\mu_{\mathrm{CXv}}=\mu_{\mathrm{CXnv}}=\right.$ $\left.\mu_{\mathrm{CBv}}=\mu_{\mathrm{CBnv}}=\mu_{\mathrm{TEv}}=\mu_{\mathrm{TEnv}}=\mu_{\mathrm{MDv}}=\mu_{\mathrm{MDnv}}\right)$, enquanto que, conseqüentemente, $\mathrm{a}$ hipótese alternativa implica que exista diferença entre as médias $\left(\mathrm{H}_{A}: \mu_{\mathrm{CAv}} \neq \mu_{\mathrm{CAnv}} \neq\right.$ $\left.\mu_{\mathrm{CXv}} \neq \mu_{\mathrm{CXnv}} \neq \mu_{\mathrm{CBv}} \neq \mu_{\mathrm{CBnv}} \neq \mu_{\mathrm{TEv}} \neq \mu_{\mathrm{TEnv}} \neq \mu_{\mathrm{MDv}} \neq \mu_{\mathrm{MDnv}}\right)$

A análise de variância verifica se há diferenças significativas entre as proporções de mortalidades provenientes da prova de isolamento viral, para os fragmentos de todos os animais vacinados e não vacinados (tratamento) e, caso estas diferenças existam, 
então pode-se inferir que tais fragmentos apresentam resultados de interpretação distintos quanto à variável testada. Entretanto, um dos pressupostos para a realização da ANOVA é que haja homocedasticidade (i.e., "homogeneidade das variâncias"), entre os dados a serem analisados. Isto quer dizer que a variação devido ao acaso, dentro de cada tratamento, deve ser a mesma. Portanto, antes de aplicar o teste, procurou-se detectar se este pressuposto seria obedecido, utilizando-se o teste de homocedasticidade de Levene (ZAR 1999), também presente no Statistica 5.1(STATSOFT INCORPORATION 1997).

Por último, a fim de verificar se existiam diferenças entre as taxas de mortalidade de camundongos inoculados com suspensões preparadas com diferentes fragmentos do SNC de eqüídeos, considerando se o animal foi submetido à eutanásia ou morreu naturalmente, também se recorreu à análise de variância de dois fatores (Two-Way ANOVA; SOKAL e ROLHF 1995). A hipótese nula, neste caso, é que as médias de proporção de mortalidade de camundongos inoculados com suspensões obtidas a partir dos diferentes fragmentos do SNC, de animais que morreram naturalmente ou foram submetidos a eutanásia, devem ser iguais $\left(\mathrm{H}_{0}: \mu_{\mathrm{CAnat}}=\mu_{\mathrm{CAsacr}}=\mu_{\mathrm{CXnat}}=\mu_{\mathrm{CXsacr}}=\mu_{\mathrm{CBnat}}=\right.$ $\left.\mu_{\mathrm{CBsacr}}=\mu_{\mathrm{TEnat}}=\mu_{\mathrm{TEsacr}}=\mu_{\mathrm{MDnat}}=\mu_{\mathrm{MDsacr}}\right)$, enquanto que, conseqüentemente, a hipótese alternativa implica que exista diferença entre as médias $\left(\mathrm{H}_{A}: \mu_{\mathrm{CAnat}} \neq \mu_{\mathrm{CAsacr}} \neq \mu_{\mathrm{CXnat}} \neq\right.$ $\left.\mu_{\mathrm{CX} \text { sact }} \neq \mu_{\mathrm{CBnat}} \neq \mu_{\mathrm{CBsact}} \neq \mu_{\mathrm{TEnat}} \neq \mu_{\mathrm{TEsacr}} \neq \mu_{\mathrm{MDnat}} \neq \mu_{\mathrm{MDsacr}}\right)$

Nesta análise, determinou-se como primeiro fator o tipo de óbito e como segundo fator os diferentes fragmentos do SNC, procurando-se verificar se o tipo de óbito do animal é ou não um fator que pode interferir no diagnóstico da raiva realizado em diferentes fragmentos. 


\section{RESULTADOS E DISCUSSÃO}

Os resultados obtidos nesta pesquisa, pela IFI com anticorpos monoclonais produzidos pelo CDC-Atlanta, contra a nucleoproteína do vírus da raiva, confirmaram, em todos os 55 casos, a identificação da variante-3 do vírus rábico, cujo reservatório é o morcego hematófago (Desmodus rotundus). Na América Latina (entre o norte do México e o norte da Argentina), em função da presença do morcego hematófago Desmodus rotundus, a raiva eqüina ocorre com maior frequência. No Brasil e, particularmente, no Estado de São Paulo, a raiva nesses animais vem assumindo importância, especialmente pelas campanhas de vacinação simultâneas contra a raiva e a febre aftosa, que determinam adequada imunidade populacional em bovinos e deixam a população eqüina sem imunidade, visto que o produtor não tem o hábito de vacinar os eqüídeos*.

* CPCR: Coordenação do Programa de Controle da Raiva do Estado de São Paulo 


\subsection{Análise das concentrações de antígenos virais em distintos fragmentos do SNC}

Com a finalidade de atingir os objetivos propostos neste trabalho, o teste do ChiQuadrado foi utilizado para verificação das diferenças entre as concentrações de antígeno viral, avaliadas pela IFD, em distintos fragmentos do SNC de eqüídeos e mostrou a existência destas diferenças para o diagnóstico da raiva $\left(\chi_{(20)}^{2}=33,550 ; p=0,029\right)$, ou seja, há associação (dependência) entre a concentração de antígenos virais, na forma de inclusões virais, e o tipo de fragmento do SNC considerado.

Como os números de fragmentos foram previamente definidos (fixados) e o ChiQuadrado mostrou haver dependência entre as variáveis, deve-se completar o teste com uma análise de homogeneidade, verificando-se entre quais fragmentos e classes de concentrações de antígenos virais estão sendo verificadas as diferenças.

Para tanto, compararam-se as probabilidades estimadas para os fragmentos em cada um dos niveis encontrados (classes) e, assim, detectaram-se quais eram as proporções discrepantes na análise, ou seja, entre quais grupos estavam sendo produzidas as diferenças encontradas.

Tais diferenças também podem ser observadas ao analisar a tabela 1, em que discrepâncias entre efeitos observados e esperados pelo teste de Chi-quadrado emergem em padrões sutis, correspondendo às maiores freqüências residuais geradas. Assim, quanto maior a freqüência residual (i.e., valores observados - esperados), maior a probalidade de tal freqüência ser a responsável pela dependência entre as variáveis detectadas pelo teste. 
Foram considerados, para a realização da análise, os maiores valores de concentração de antígeno viral verificados entre as três lâminas examinadas pela IFD.

Tabela 1 - Valores observados e esperados ( ) pelo teste de Chi-Quadrado, para a verificação de independência entre concentração viral e fragmento do SNC usado no diagnóstico de raiva de 35 eqüídeos $\left(n=35 ; N_{\text {frag }}=175\right)$

\begin{tabular}{lccccccc}
\hline \multirow{2}{*}{ Fragmento Classe (concentração antígeno viral) } \\
\cline { 2 - 8 } & 0 & 1 & 2 & 3 & 4 & 5 & Total \\
\cline { 2 - 8 } & $14(8,2)$ & $5(8)$ & $9(5)$ & $2(5,2)$ & $5(7,4)$ & $0(1,2)$ & $35(35)$ \\
CA & $11(8,2)$ & $7(8)$ & $3(5)$ & $4(5,2)$ & $8(7,4)$ & $2(1,2)$ & $35(35)$ \\
CB & $11(8,2)$ & $11(8)$ & $2(5)$ & $6(5,2)$ & $4(7,4)$ & $1(1,2)$ & $35(35)$ \\
TE & $2(8,2)$ & $10(8)$ & $5(5)$ & $6(5,2)$ & $10(7,4)$ & $2(1,2)$ & $35(35)$ \\
MD & $3(8,2)$ & $7(8)$ & $6(5)$ & $8(5,2)$ & $10(7,4)$ & $1(1,2)$ & $35(35)$ \\
& & & & & & & \\
Total & $41(41)$ & $40(40)$ & $25(25)$ & $26(26)$ & $37(37)$ & $6(6)$ & $175(175)$ \\
\hline
\end{tabular}

Os resultados são melhor ilustrados na figura 7, na qual as concentrações virais tendem a ser menores nos fragmentos $\mathrm{CA}, \mathrm{CX}$ e $\mathrm{CB}$, uma vez que para estes verifica-se um maior número de observações nas classes mais baixas (zero, 1 e 2), quando comparados aos fragmentos TE e MD. As equações das retas sobrepostas aos diagramas de barras, na figura 7, confirmam esta tendência.

Enquanto CA, CX e CB tendem a apresentar uma maior frequência de valores baixos de concentração viral, TE e MD tendem a valores mais homogêneos, com sutis aumentos no número de observações para as classes 3,4 e 5 . 
$\mathrm{O}$ fato de os fragmentos TE e MD apresentarem maiores concentrações virais que os demais, deve ser interpretado como um valioso resultado para a realização de diagnósticos de raiva pelo método da IFD, pois, ao produzirem valores mais homogêneos de concentração viral, mostram uma maior precisão (i.e., acurácia) para o diagnóstico.

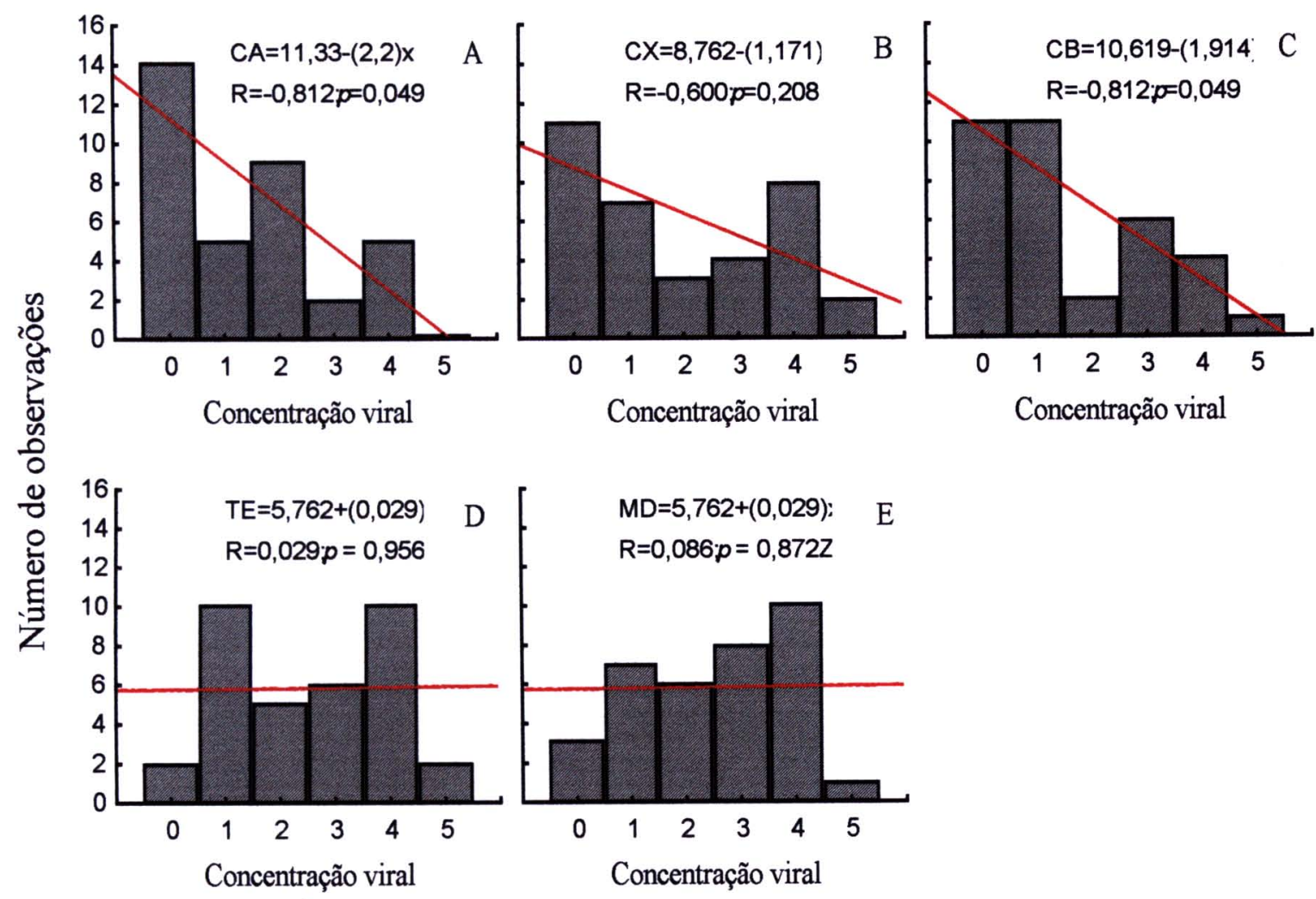

Figura 7 - Freqüências de observação para seis classes de concentrações virais (na forma de corpúsculo de inclusão) em cinco fragmentos do SNC de 35 eqüídeos. A concentração de antígeno viral é diferente entre classes e fragmentos distintos para $\chi_{(20)}^{2}=33,550 ; p=$ 0,029. São Paulo, 2000 - 2003.

A. Corno de Amon; B. Córtex; C. Cerebelo; D. Tronco encefálico; E. Medula. 
Embora vários autores (TRIMARCHI e DEBBIE 1991; IWASAKI e TOBITA 2002) tenham considerado o hipocampo e o cerebelo como os melhores tecidos para demonstração de inclusões de Negri no diagnóstico da raiva em bovinos, pela apresentação de grandes inclusões na IFD, LEE e BECKER (1972) em um estudo realizado em oito espécies animais, e ITO e col. (1985), em experimento realizado com cães demontraram a efícácia do exame de fragmentos da medula para o diagnóstico da raiva pela IFD. LEE e BECKER (1972) ao analisarem 10.403 amostras, sendo 384 positivas para raiva, concluiram que a irregularidade da distribuição do antígeno viral faz com que, várias vezes, não se detecte este antígeno no cérebro e o exame da medula é uma alternativa para melhorar a segurança do diagnóstico.

ITO e col. (1985), com o objetivo de determinar a presença de vírus rábico em diferentes segmentos do SNC em cães raivosos, trabalharam com 37 animais, sendo 31 infectados naturalmente e 6 infectados experimentalmente, pesquisando a presença de vírus pelas técnicas de IFD e IIC. Estes autores encontraram 100\% de resultados positivos pelas IFD e IIC em todos fragmentos dos animais infectados experimentalmente (CA, CB, bulbo, medula cervical, torácica, lombar e sacral). Nos animais naturalmente infectados foram observadas diferenças de positividade nas duas provas utilizadas. A IFD foi $100 \%$ positiva para encéfalo e medula, com excessão da medula torácica $(96,7 \%)$. O teste de IIC resultou $100 \%$ de positividade para o encéfalo e a medula lombar; $96,7 \%$ para a medula cervical e $93,5 \%$ para as medulas torácica e sacral. Os autores não encontraram, portanto, nenhuma amostra que resultasse negativa para segmentos do encéfalo, pela IF ou IIC. Estes mesmos autores têm defendido a validade em examinar a medula, quando fragmentos de cérebro não são viáveis. 
Outros autores (ROBINSON e DISALVO 1980; TRIMARCHI e col. 1986), ao estudarem raiva felina, demonstraram antígeno rábico em algumas regiões do $\mathrm{SNC}$, não sendo possível demonstrá-lo em outras. TRIMARCHI e col. (1986) verificaram, em um experimento de infecção de 4 gatos pelo vírus rábico isolado de morcego Eptesicus fuscus, que os diferentes fragmentos (córtex, cerebelo, hipocampo, tronco encefálico e medula) apresentaram níveis de concentração de antígeno distintos.

BURNES e col. (1991) também descreveram distribuição e grau de fluorescência em distintas porcentagens quando analisadas diferentes regiões do encéfalo (corno de Amon, córtex e cerebelo). Este estudo foi realizado em 278 animais sendo $79 \%$ da espécie canina. TABEL e CHARLTON (1974) e MEYER e col. (1986) ao estudarem casos de raiva em eqüinos obtiveram resultados negativos pela IFD, trabalhando com hipocampo e cerebelo.

No presente trabalho, de 39 eqüídeos dos quais foi possível coletar 4 fragmentos do encéfalo (CA, CX,CB e TE), apenas 11 (29,2\%) apresentaram resultados positivos para todos os fragmentos nas duas técnicas, demonstrando a diversidade de resultados, dependendo do fragmento. No que diz respeito à medula, de 48 eqüídeos, dos quais foi possível a coleta destes fragmentos, $36(75 \%)$ apresentaram resultados positivos por ambas as técnicas.

Para maior segurança, cerebelo, tronco encefálico e hipocampo, dos dois hemisférios cerebrais devem ser examinados de todos espécimes (TRIMARCHI e col 1986; CHARLTON 1988).

BINGHAM e VAN DER MERWE (2002) trabalharam com diferentes fragmentos de 252 cérebros de animais positivos para raiva, pertencentes a várias espécies e observaram, ao estabelecer um score para leitura da prova de IFD, frequientes diferenças 
entre as concentrações de antígeno das várias regiões do SNC. Estes autores consideraram que o tálamo, bulbo e a medula foram as partes mais confiáveis para expressar um resultado positivo. O cerebelo, o hipocampo e diferentes partes do cérebro foram negativos respectivamente em $4,5 \%, 4,9 \%$ e 3,9 a $11 \%$. Estes resultados condradizem muitos outros estudos que mencionaram o hipocampo como estrutura de escolha para o diagnóstico da raiva (TIERKEL 1976; LÉPINE e ATANASIU 1996). BINGHAM e VAN DER MERWE (2002) trabalharam, no entanto, apenas com quatro eqüídeos e os resultados apresentados não esclarecem qual o melhor fragmento para raiva nesta espécie.

Segundo TRIMARCHI e SMITH (2002), a presença, distribuição e tamanho dos corpúsculos de inclusão estão relacionados às espécies animais, variantes de vírus rábico e duração do período clínico antes da morte.

Segundo CHARLTON (1988) os diferentes mecanismos responsáveis pela raiva paralítica e furiosa não têm sido claramente estabelecidos. De acordo com Chopra e col. (1980) citado por CHARLTON (1988), a raiva paralítica no homem é caracterizada pela destruição das células nervosas, proliferação da microglia e infiltração perivascular, principalmente, na medula e tronco encefálico, enquanto que, na raiva clássica furiosa, a reação inflamatória, alterações vasculares e corpúsculos de inclusão são muito mais difusos no tálamo, hipotálamo, cerebelo e cortex cerebral. Lesões da raiva paralítica são sempre encontradas no tronco encefálico e medula, segundo PERL e GOOD (1991). Não foram encontrados estudos comparativos de concentração do antígeno rábico nos diferentes fragmentos do SNC, das duas formas da doença: paralítica e furiosa.

Neste experimento, o fato de terem sido encontradas maiores concentrações de vírus no TE e MD reforça a necessidade de se coletar estes dois fragmentos, especialmente quando se tratar de raiva paralítica e com suspeita de transmissão pelo Desmodus rotundus, 
diferentemente dos resultados obtidos por pesquisadores que estabeleceram comparações entre as técnicas diagnósticas e fragmentos do $\mathrm{SNC}$, ao estudarem casos de raiva furiosa transmitida por carnívoros terrestres (ROBINSON e DISALVO 1980; GREEN e col. 1992).

Embora a literatura científica seja escassa, para a espécie eqüina, com referência à influência da variante viral na concentração do antígeno para os diferentes fragmentos, é importante ressaltar o trabalho de MARTELL e col. (1969) que, estudando cérebros de ovinos com raiva paralítica, através da IFD, notaram maior intensidade de fluorescência no bulbo, tálamo e córtex, sendo o cerebelo negativo ou fracamente positivo. SCHEIFSTEIN e TOPKINS (1951) verificaram, no entanto, que em bovinos agredidos por raposas o cerebelo era o local de eleição para o diagnóstico.

MACRUZ e col. (1977) verificaram que,em bovinos infectados experimentalmente, a medula se mostrou o melhor fragmento para o diagnóstico pelos métodos histopatológicos, IFD e inoculação em camundongos.

Os resultados, obtidos, neste experimento, pela pesquisa de vírus rábico, através da IFD, em diferentes fragmentos do SNC de eqüídeos, revelam que o tronco encefálico e a medula são os fragmentos que apresentam as classes mais altas e possuem valores mais homogêneos, do que o CA, CX e CB e diferem, também, daqueles obtidos por KEANE e LITLLE (1987), que encontraram corpúsculos de inclusão com maior frequência nas células de Purkinje do cerebelo, nos neurônios do hipocampo e nas células piramidais da córtex cerebral, do que no tálamo, bulbo e medula.

Ressalta-se que SILVA e col. (1974) já haviam relatado 2 casos de raiva em eqüinos, nos quais não se constatou vírus no cérebro e cerebelo, e sim na medula de um e no bulbo de outro. Estes autores obtiveram resultados discordantes de vários pesquisadores, 
que afirmavam ser freqüente a falta de inclusões em eqüinos infectados pelo vírus da raiva. Os resultados obtidos por SILVA e col. (1974) já demonstravam o desconhecimento da patogenia da raiva transmitida pelo Desmodus rotundus a eqüídeos .

Mais recentemente, PEIXOTO e col (2000) ao examinarem 703 amostras de eqüídeos, verificaram $76,6 \%$ de sensibilidade da técnica de IFD, quando comparada ao isolamento de vírus em camundongos. Esses autores não fizeram distinção entre os fragmentos utilizados para a realização do diagnóstico laboratorial.

Na tabela 2 são apresentados resultados de sensibilidade da IFD e IIC para os distintos fragmentos estudados em 55 eqüídeos. Pode-se verificar, nesta tabela, que os fragmentos de TE e MD apresentraram sensiblidade de $95,8 \%$, porém, para o CA foi $68,1 \% ;$ CX $74,5 \%$ e CB 74, $1 \%$.

Tabela 2 - Sensibilidade das técnicas de IFD e IVC para os cinco fragmentos de SNC de 55 eqüídeos. São Paulo, 2000 - 2003.

\begin{tabular}{|c|c|c|c|c|c|c|}
\hline \multirow[t]{2}{*}{ Fragmentos } & \multicolumn{2}{|c|}{ Positivos } & \multicolumn{2}{|c|}{ Negativos } & \multicolumn{2}{|c|}{ Total } \\
\hline & $n I$ & $\%$ & $n 2$ & $\%$ & $N$ & $\%$ \\
\hline $\mathrm{CA}$ & 32 & 68,1 & 15 & 31,9 & 47 & 19,0 \\
\hline $\mathrm{CX}$ & 38 & 74,5 & 13 & 25,5 & 51 & 20,6 \\
\hline $\mathrm{CB}$ & 40 & 74,1 & 14 & 25,9 & 54 & 21,8 \\
\hline $\mathrm{TE}$ & 46 & 95,8 & 2 & 4,2 & 48 & 19,4 \\
\hline MD & 46 & 95,8 & 2 & 4,2 & 48 & 19,4 \\
\hline TOTAL & 202 & 81,5 & 46 & 18,5 & 248 & 1,0 \\
\hline
\end{tabular}


A tabela 3 apresenta uma análise sobre a matriz de correlação constituída com todos os fragmentos (CA, CX, CB, TE e MD), mostrando evidentes diferenças entre as concentrações virais nos fragmentos do SNC dos 35 eqüídeos analisados.

Esta análise mostra que correlações mais fortes são encontradas para fragmentos de dois grupos: um primeiro grupo, formado pelos fragmentos de $\mathrm{CA}, \mathrm{CX}, \mathrm{CB}$, e um segundo grupo, constituído pelo TE e MD. Dentro do primeiro grupo, observam-se fortes e positivas correlações entre CA e CX $(R=0,638)$ e $C X$ e $C B(R=0,783)$, enquanto que, as correlações mais fracas e negativas se dão justamente entre $\mathrm{CA}$ e os outros dois tipos de fragmentos, TE $(R=-0,090)$ e $M D(R=-0,029)$. No segundo grupo, por sua vez, verificase que os fragmentos do TE e MD estão fortemente correlacionados, conforme mostra seu coeficiente de correlação $(R=0,883)$.

Tabela 3 - Análise de correlação, estabelecida entre fragmentos do SNC de 35 eqüídeos, tendo-se como base o número de observações (freqüências) de cada classe de concentração viral nos diferentes fragmentos. São Paulo, 2000 - 2003.

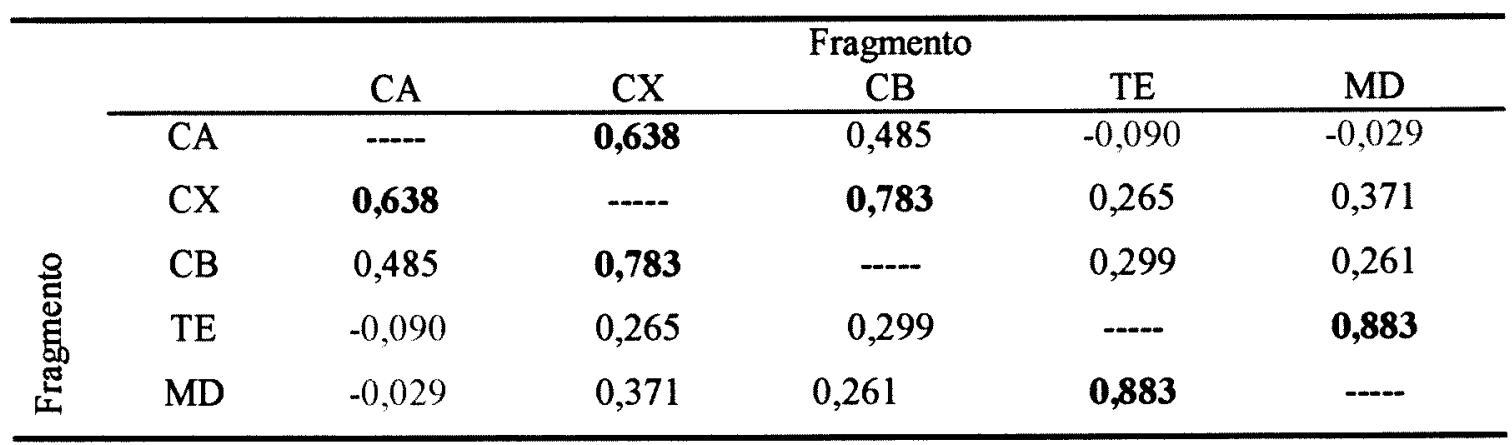


Os números da tabela 3 referem-se ao coeficiente de correlação de Spearman (SPEARMAN 1904), mostrando em negrito as correlações com coeficientes maiores que $60 \%$ e, em vermelho, aquelas abaixo de $10 \%$.

Ao realizar-se uma abordagem pelas diferentes concentrações, ao invés dos fragmentos, pode-se notar que o padrão anteriormente citado é formado principalmente pelas concentrações virais incluídas na classe 3 , em que fica evidente uma maior incidência de ocorrências nos fragmentos TE e MD $(\mathrm{R}=0,975 ; p=0,005)$, em contrapartida com a incidência de ocorrências da classes 0 nos fragmentos $\mathrm{CA}, \mathrm{CX}$ e $\mathrm{CB}$, ainda que estas diferenças não tenham se mostrado significativas $(R=-0,872 ; p=0,054)$. A figura 8 ilustra as relações entre todas as classes de concentração viral e os fragmentos usados no diagnóstico da raiva.

MASERANG e col. 1981, nos Estados Unidos, analisaram fragmentos de CA e CB de 1730 animais, de diversas espécies, positivos para raiva, durante o período compreendido entre 1977-79. Apenas 37 animais foram positivos para um só fragmento: 27 somente para $\mathrm{CB}$ e 10 somente para o $\mathrm{CA}$. Destes 1730 animais, 166 eram eqüinos, tendo havido concordância em 164 animais e discordância apenas em 2 (um positivo apenas para o CB e outro apenas para o CA).

No presente estudo foi verificada uma correlação intermediária $(R=0,485)$ entre CA e CB conforme demonstrado na tabela 3. As diferenças obtidas nos dois trabalhos podem estar relacionadas à fonte de infeç̧ão, ou seja, à variante viral. 

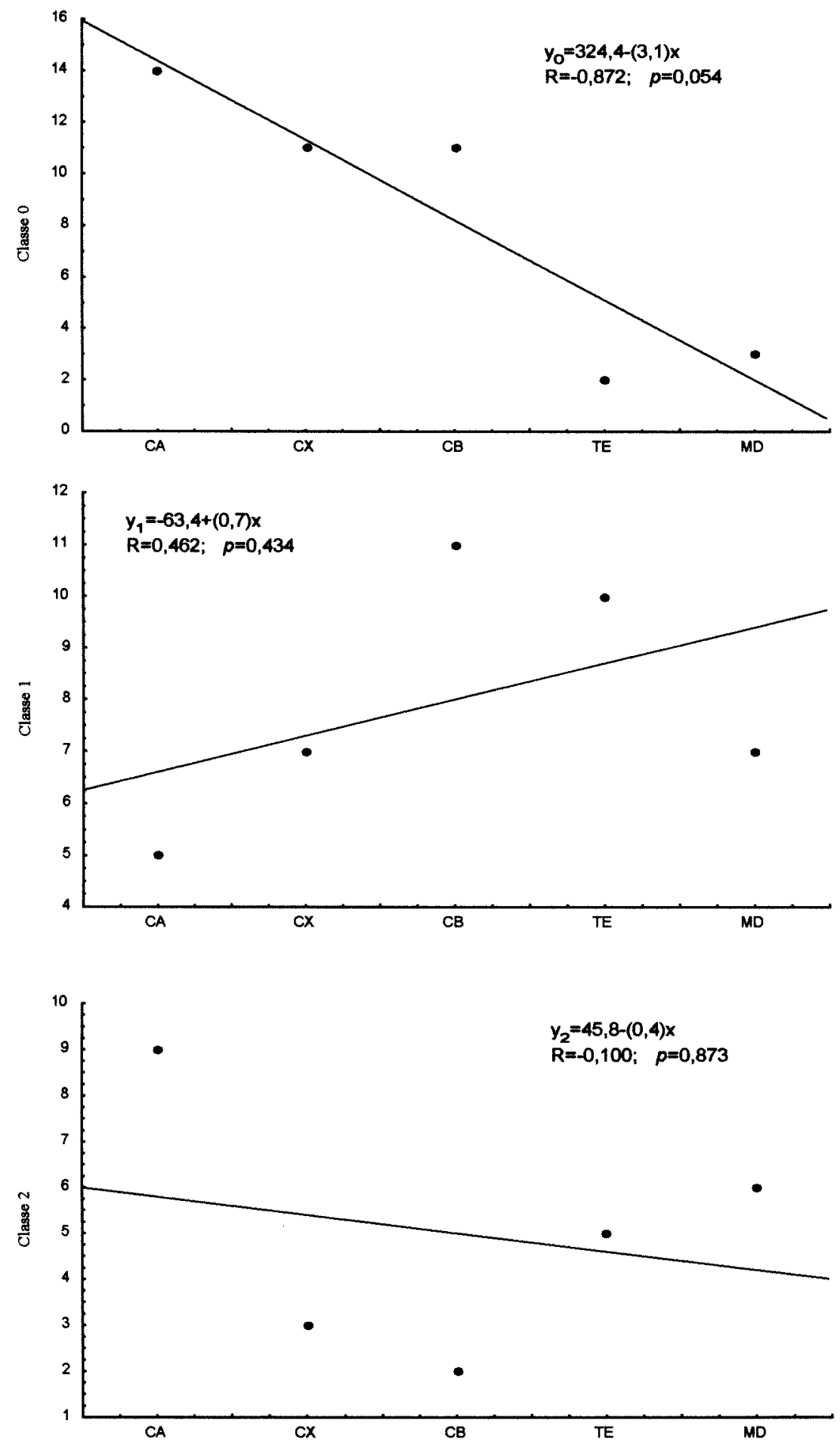

Figura 8 - Relações entre a freqüência de observação de diferentes concentrações de antígenos virais, classes $0-5$, e os fragmentos usados para o diagnóstico de raiva em eqüídeos, $(n=35)$. São Paulo, $2000-2003$.

A. Corno de Amon; B. Córtex; C. Cerebelo; D. Tronco encefálico; E. Medula. 

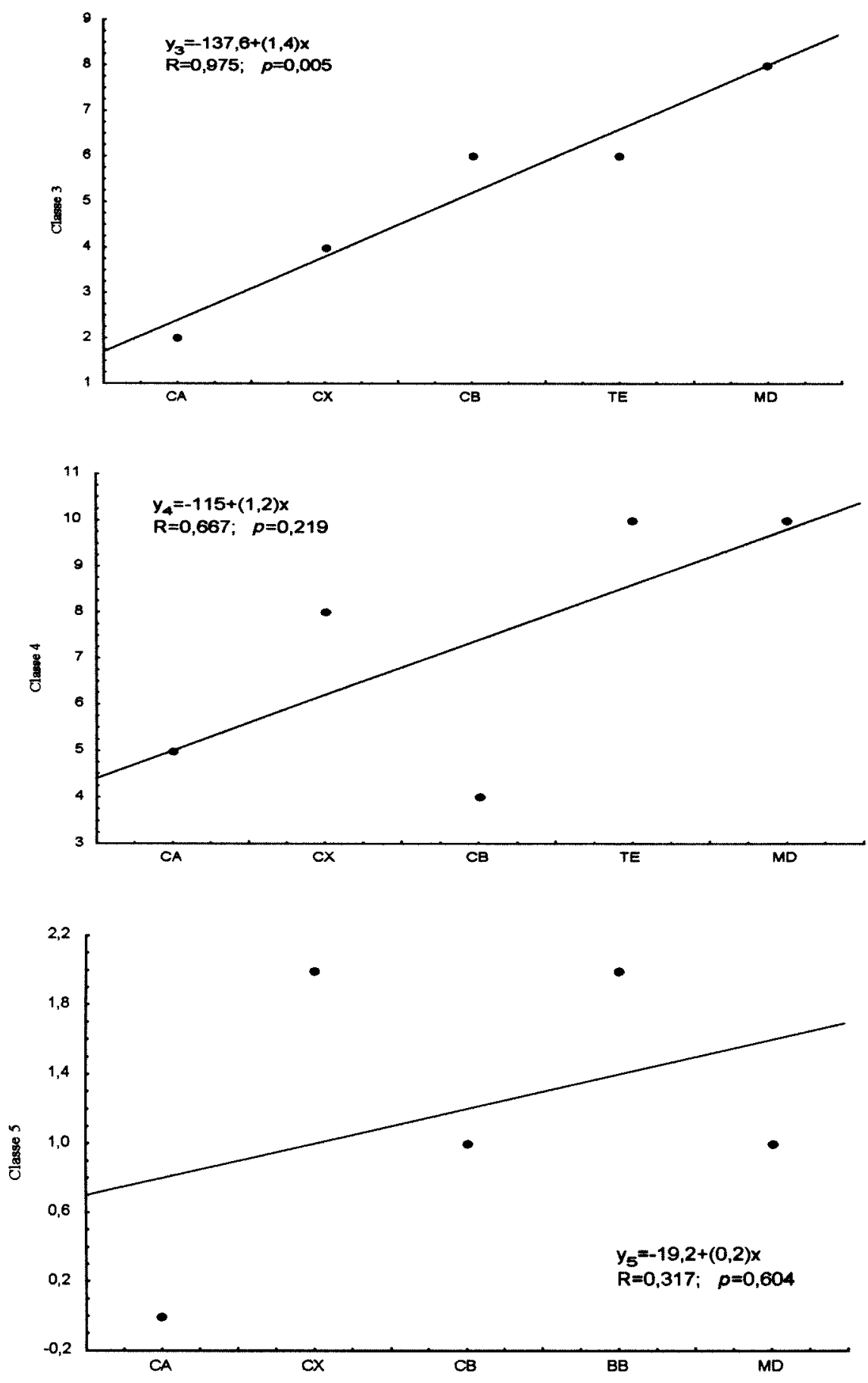

Figura 8 - Relações entre a freqüência de observação de diferentes concentrações de antígenos virais, classes $0-5$, e os fragmentos usados para o diagnóstico de raiva em eqüídeos, $(n=35)$. São Paulo, $2000-2003$.

A. Corno de Amon; B. Córtex; C. Cerebelo; D. Tronco encefálico; E. Medula. 


\subsection{Análise das concentrações de antígenos virais e histórico de vacinação}

Em relação à influência da vacinação sobre a interpretação dos resultados, a tabela 4 demonstra os resultados obtidos pelo teste de Chi-Quadrado, para a verificação de independência entre fragmentos diagnósticos e as seis classes pré-determinadas de concentração de antígeno viral, levando em consideração se o animal, do qual foram coletados os fragmentos, havia sido, ou não, vacinado anteriormente ao aparecimento dos sintomas da raiva.

Tabela 4 - Valores observados e esperados ( ) pelo teste de Chi-Quadrado, para a verificação de independência entre concentração viral e fragmento do SNC aplicado ao diagnóstico de raiva de 32 eqüídeos, considerando se estes animais foram ou não previamente vacinados. São Paulo, $2000-2003$. $\left(n=32, N_{\text {frag }}=160 ; \chi_{(49)}^{2}=63,974, p=\right.$ 0,074).

\begin{tabular}{|c|c|c|c|c|c|c|c|}
\hline \multirow{2}{*}{ Estado } & \multicolumn{6}{|c|}{ Classes de concentração viral } & \multirow{2}{*}{ Total } \\
\hline & 0 & 1 & 2 & 3 & 4 & 5 & \\
\hline Vacinado & & & & & & & \\
\hline $\mathrm{CA}$ & $7(4,5)$ & $3(4,05)$ & $6(2,7)$ & $1(2,81)$ & $1(3,49)$ & $0(0,45)$ & 18 \\
\hline $\mathrm{CX}$ & $4(4,5)$ & $6(4,05)$ & $2(2,7)$ & $2(2,81)$ & $4(3,49)$ & $0(0,45)$ & 18 \\
\hline $\mathrm{CB}$ & $5(4,5)$ & $5(4,05)$ & $1(2,7)$ & $6(2,81)$ & $1(3,49)$ & $0(0,45)$ & 18 \\
\hline TE & $1(4,5)$ & $4(4,05)$ & $4(2,7)$ & $4(2,81)$ & $5(3,49)$ & $0(0,45)$ & 18 \\
\hline MD & $2(4,5)$ & $3(4,05)$ & $4(2,7)$ & $4(2,81)$ & $5(3,49)$ & $0(0,45)$ & 18 \\
\hline Total & $19(22,5)$ & $21(20,25)$ & $17(13,5)$ & $17(14,06)$ & $16(17,44)$ & $0(2,25)$ & 90 \\
\hline \multicolumn{8}{|l|}{$\begin{array}{c}\text { Não } \\
\text { vacinado }\end{array}$} \\
\hline $\mathrm{CA}$ & $7(3,5)$ & $1(3,15)$ & $3(2,1)$ & $1(2,19)$ & $2(2,71)$ & $0(0,35)$ & 14 \\
\hline $\mathrm{CX}$ & $6(3,5)$ & $1(3,15)$ & $1(2,1)$ & $1(2,19)$ & $3(2,71)$ & $2(0,35)$ & 14 \\
\hline CB & $6(3,5)$ & $5(3,15)$ & $0(2,1)$ & $0(2,19)$ & $2(2,71)$ & $1(0,35)$ & 14 \\
\hline $\mathrm{TE}$ & $1(3,5)$ & $5(3,15)$ & $1(2,1)$ & $2(2,19)$ & $4(2,71)$ & $1(0,35)$ & 14 \\
\hline MD & $1(3,5)$ & $3(3,15)$ & $2(2,1)$ & $4(2,19)$ & $4(2,71)$ & $0(0,35)$ & 14 \\
\hline Total & $21(17,5)$ & $15(15,75)$ & $7(10,5)$ & $8(10,94)$ & $15(13,56)$ & $4(1,75)$ & 70 \\
\hline Total geral & 40 & 36 & 24 & 25 & 31 & 4 & 160 \\
\hline
\end{tabular}


Após a realização do teste, verifica-se que não existe dependência entre as variáveis "fragmento diagnóstico", "vacinação" e "concentração viral” $\left(\chi_{(49)}^{2}=63,974 ; p=0,074\right)$, ou seja, o número de observações encontrado para diferentes classes de concentração viral em diferentes tipos de fragmentos é o mesmo, sendo este independente do estado prévio do animal, se fora ou não vacinado anteriormente ao aparecimento de sintomas de raiva.

Quando a análise é desmembrada entre os dois estados do animal quanto à vacinação (vacinado ou não vacinado), também não se verifica dependência entre as variáveis, para animais vacinados $\left(\chi_{(20)}^{2}=21,810 ; p=0,351\right)$ nem para não vacinados $\left(\chi_{(20)}^{2}=27,917 ; p=0,111\right)$. Tais resultados são melhor visualizados nas figuras 9 e 10.

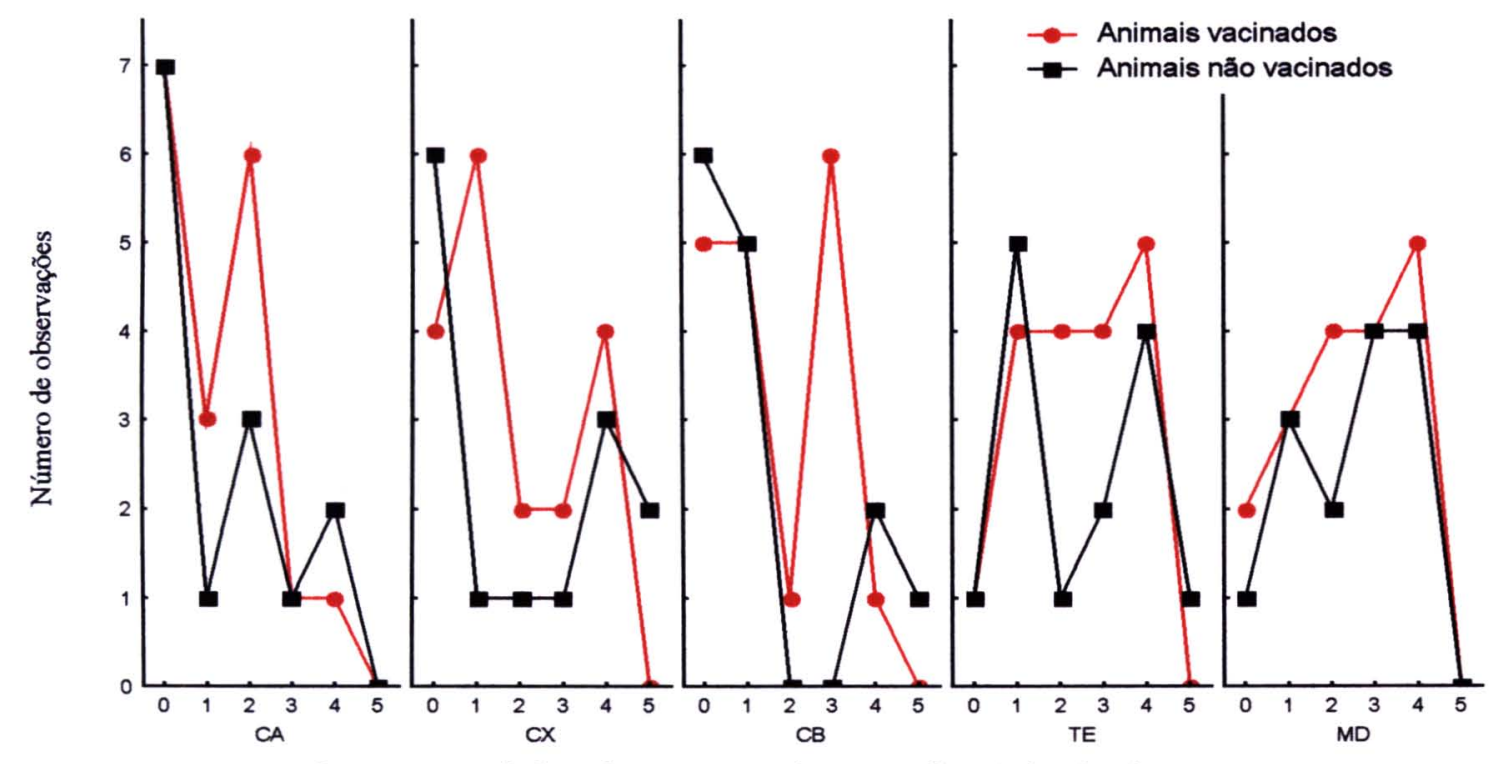

Concentração viral em fragmentos usados para o diagnóstico da raiva

Figura 9 Variação das freqüências obtidas para diferentes classes de concentrações virais $(0-5)$, comparadas entre fragmentos usados para o diagnóstico da raiva provenientes de 32 eqüídeos, sendo 18 vacinados e 14 não vacinados. São Paulo, 2000 - 2003.

$(\mathrm{CA}=$ Corno de Amon $; \mathrm{CX}=$ Córtex $\mathrm{CB}=$ Cerebelo, $\mathrm{TE}=$ Tronco encefálico $; \mathrm{MD}=$ Medula 


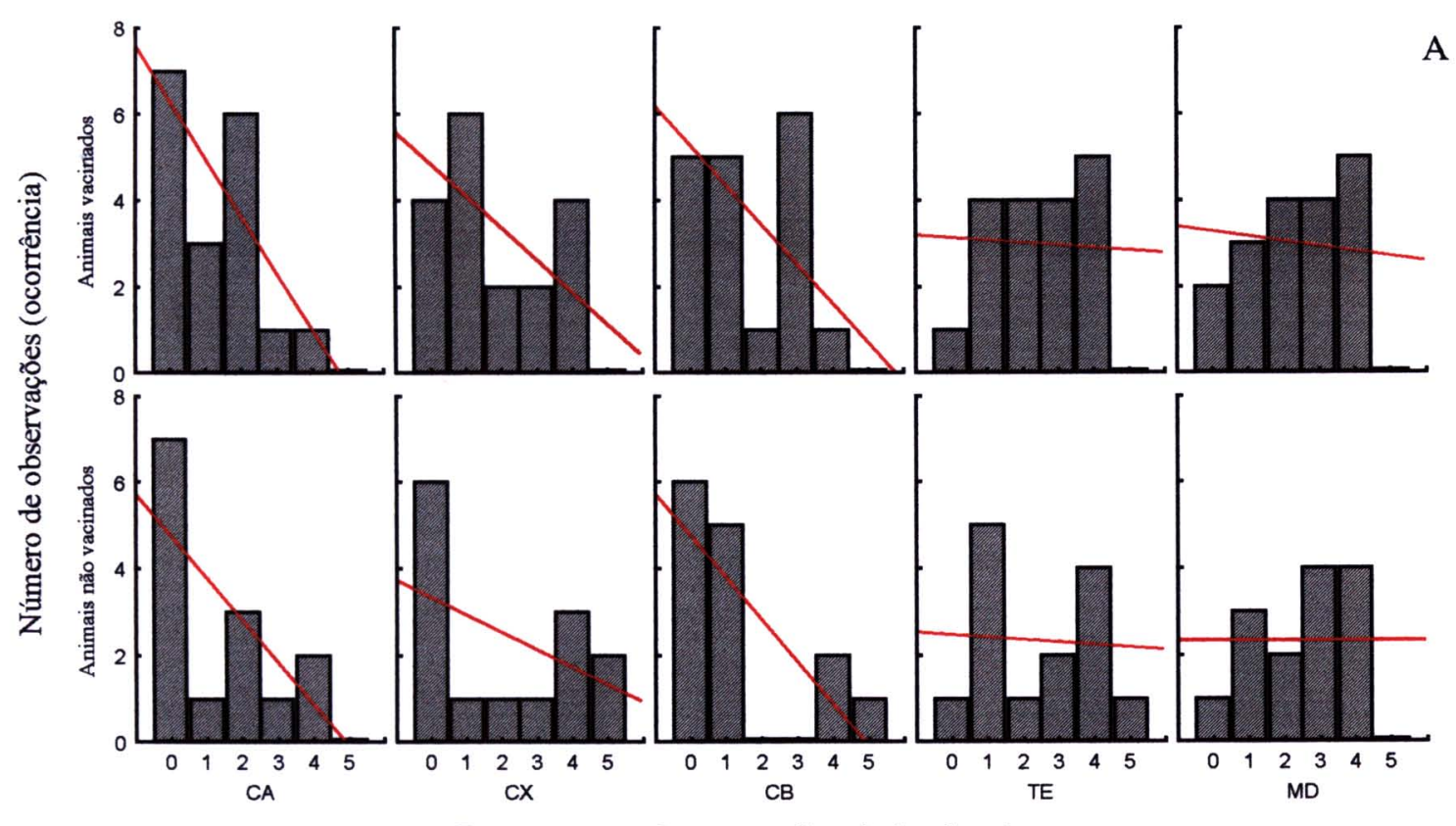

Fragmentos usados para o diagnóstico da raiva

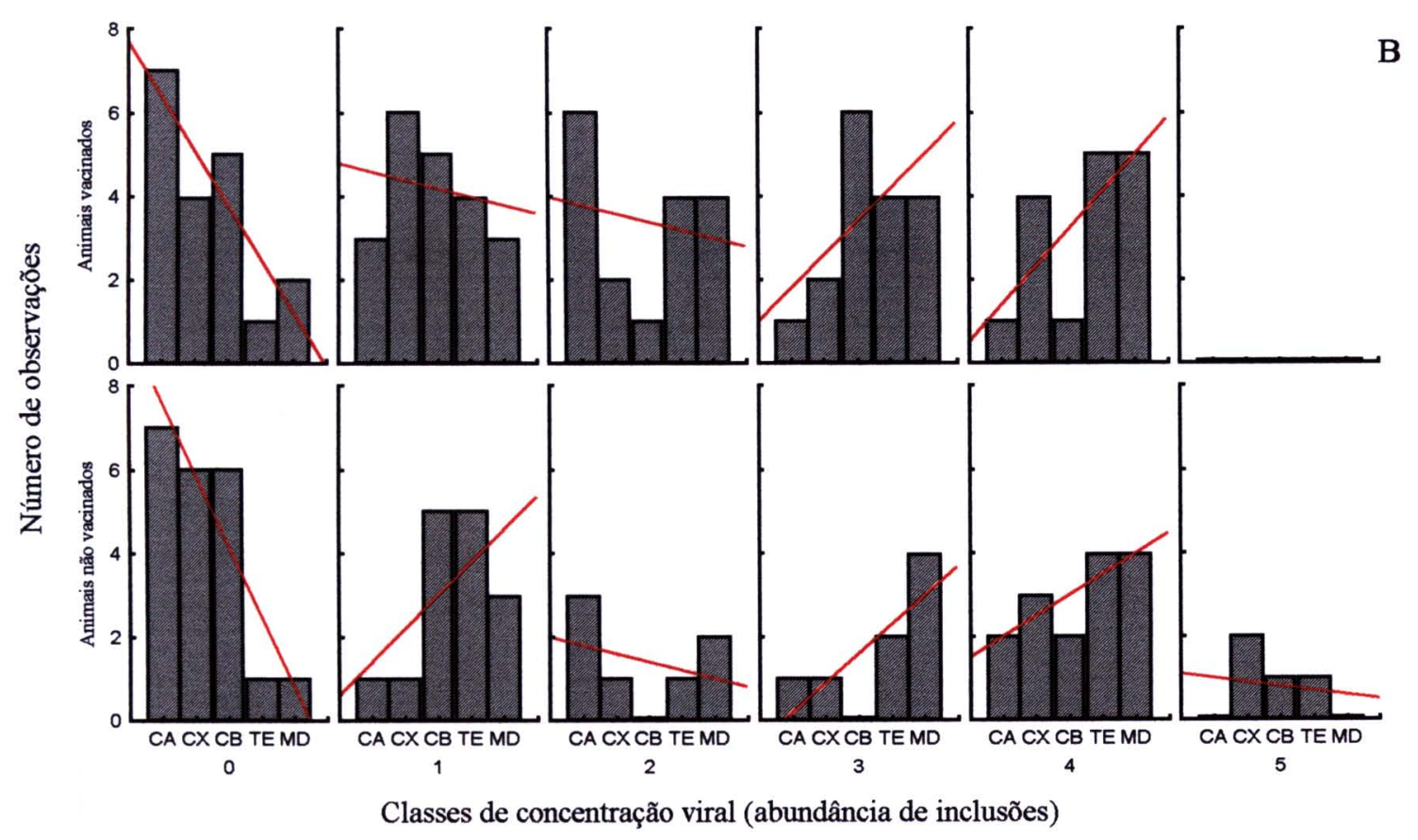

Figura 10 - Freqüência de observação para concentrações virais e fragmentos do SNC de 32 eqüídeos, sendo 18 vacinados e 14 não vacinados. A. Variação das seis classes de concentrações virais pelos cinco tipos fragmentos usados no diagnóstico da raiva. $\mathbf{B}$. Variação entre os fragmentos em uma mesma classe CA; CX; CB; TE; MD. São Paulo, 200-2003. 
Não houve dependência entre as variáveis, ao serem analisadas em conjunto $\left(\chi^{2}{ }_{(49)}=\right.$ $63,974, p=0,074)$ e separadamente, entre animais vacinados $\left(\chi_{(20)}^{2}=21,810, p=0,351\right)$ ou não vacinados $\left(\chi_{(20)}^{2}=27,917, p=0,111\right)$.

Não foram encontrados na literatura dados referentes à influência da vacinação na concentração de antígeno viral nos diferentes fragmentos. GREEN e col. 1992, ao induzirem infecção experimental em 21 eqüinos, observaram apenas que animais não vacinados apresentaram período de incubação e período de morbidade mais curto. HUDSON e col. (1996), trabalhando com o mesmo número de animais (21), infectados experimentalmente, sendo 12 não vacinados e 9 vacinados, observaram os mesmos resultados que foram estatisticamente significantes.

Em nosso experimento, face ao pequeno número de animais com informação sobre período de morbidade, e ausência de informação sobre o período de incubação, não foi possível estabelecer esta relação.

Como 18 animais apresentaram histórico de vacinação (uma ou mais doses) e, mesmo assim, desenvolveram a doença, pode-se inferir que estes não possuiam resposta imune satisfatória, sugerindo que a evolução da doença ocorreu de forma semelhante à dos animais não vacinados (14), não tendo interferência no diagnóstico laboratorial.

FERMAGLICH e HOROHOV (2002) relatam que eqüinos mais "idosos" têm um declínio da função imune e um aumento da susceptibilidade às infecções. Neste experimento, dos 18 eqüídeos com histórico de vacinação, apenas 13 tinham informação sobre idade, sendo que cinco $(38,5 \%)$ apresentavam 13 anos ou mais.

Melhores observações poderiam ser realizadas caso as informações sobre data da primeira vacinação, dose da vacina, número de doses de vacina, local de aplicação, tipo de 
vacina, periodo entre as doses etc., estivessem disponíveis, assim como a idade dos animais.

\subsection{Análise das concentrações de antígenos virais e tipo de óbito}

A tabela 5 apresenta os resultados obtidos pelo teste do Chi-Quadrado para verificar a existência de independência entre os fragmentos diagnósticos e as seis classes prédeterminadas de concentração de antígeno, levando em consideração se o animal do qual foram extraídos os fragmentos morreu com evolução natural pela doença, ou foi submetido à eutanásia após o aparecimento dos sintomas. Foram considerados, para a realização da análise, os maiores valores de concentração viral verificados entre as três lâminas analisadas na IFD, para 35 animais com histórico do tipo de óbito.

Para a análise em separado, entre os dois estados da variável “óbito" (morte natural ou eutanásia), também não se verificou dependência entre as variáveis para animais que morreram espontaneamente $\left(\chi_{(20)}^{2}=21,080 ; p=0,392\right)$, nem para animais que foram submetidos à eutanásias $\left(\chi^{2}{ }_{(20)}=27,428 ; p=0,124\right)$. Os resultados estão sintetizados na tabela 5 .

Após a realização do teste, não foi constatada dependência entre as variáveis "fragmento diagnóstico", "tipo de óbito" e "concentração viral" $\left(\chi_{(49)}^{2}=59,614 ; p=0,142\right)$, ou seja, o número de observações encontrado para diferentes classes de concentração viral, em diferentes tipos de fragmentos, é o mesmo, sendo este independente do tipo de óbito ocorrido com o animal (Figuras 11 e 12). Não há dependência entre as variáveis, ao serem analisadas em conjunto $\left(\chi_{(49)}^{2}=59,614 ; p=0,142\right)$ e separadamente, entre animais que 
tiveram morte natural $\left(\chi_{(20)}^{2}=21,080 ; p=0,392\right)$ ou submetidos ao sacrificio $\left(\chi_{(20)}^{2}=\right.$ $27,428 ; p=0,124)$.

Tabela 5 -Valores observados e esperados ( ) pelo teste de Chi-Quadrado, para a verificação de independência entre concentração viral e fragmentos do SNC aplicado ao diagnóstico de raiva de 35 eqüídeos, considerando-se se estes animais morreram espontaneamente ou foram submetidos à eutanásia. São Paulo, $2000-2003$. ( $n=35, N_{\text {frag }}$ $=175) ;\left(\chi_{(49)}^{2}=59,614 ; p=0,142\right)$.

\begin{tabular}{|c|c|c|c|c|c|c|c|}
\hline \multirow{2}{*}{ Óbito } & \multicolumn{6}{|c|}{ Classes de concentração viral } & \multirow{2}{*}{ Total } \\
\hline & 0 & 1 & 2 & 3 & 4 & 5 & \\
\hline \multicolumn{8}{|l|}{ Natural } \\
\hline $\mathrm{CA}$ & $6(4,22)$ & $4(4,11)$ & $6(2,57)$ & $0(2,67)$ & $2(3,81)$ & $0(0,62)$ & 18 \\
\hline $\mathrm{CX}$ & $4(4,22)$ & $5(4,11)$ & $3(2,57)$ & $4(2,67)$ & $2(3,81)$ & $0(0,62)$ & 18 \\
\hline $\mathrm{CB}$ & $4(4,22)$ & $6(4,11)$ & $2(2,57)$ & $5(2,67)$ & $1(3,81)$ & $0(0,62)$ & 18 \\
\hline TE & $1(4,22)$ & $5(4,11)$ & $3(2,57)$ & $3(2,67)$ & $5(3,81)$ & $1(0,62)$ & 18 \\
\hline MD & $1(4,22)$ & $4(4,11)$ & $3(2,57)$ & $5(2,67)$ & $4(3,81)$ & $1(0,62)$ & 18 \\
\hline Total & $16(21,09)$ & $24(20,57)$ & $17(12,86)$ & $17(13,37)$ & $14(19,03)$ & $2(3,08)$ & 90 \\
\hline \multicolumn{8}{|l|}{ Eutanásia } \\
\hline $\mathrm{CA}$ & $8(3,98)$ & $1(3,89)$ & $3(2,43)$ & $2(2,53)$ & $3(3,59)$ & $0(0,58)$ & 17 \\
\hline $\mathrm{CX}$ & $7(3,98)$ & $2(3,89)$ & $0(2,43)$ & $0(2,53)$ & $6(3,59)$ & $2(0,58)$ & 17 \\
\hline $\mathrm{CB}$ & $7(3,98)$ & $5(3,89)$ & $0(2,43)$ & $1(2,53)$ & $3(3,59)$ & $1(0,58)$ & 17 \\
\hline TE & $1(3,98)$ & $5(3,89)$ & $2(2,43)$ & $3(2,53)$ & $5(3,59)$ & $1(0,58)$ & 17 \\
\hline MD & $2(3,98)$ & $3(3,89)$ & $3(2,43)$ & $3(2,53)$ & $6(3,59)$ & $0(0,58)$ & 17 \\
\hline Total & $25(19,91)$ & $16(19,43)$ & $8(12,14)$ & $9(12,63)$ & $23(17,97)$ & $4(2,91)$ & 85 \\
\hline Total geral & 41 & 40 & 25 & 26 & 37 & 6 & 175 \\
\hline
\end{tabular}

GREEN e col. (1992) realizando diagnóstico histológico em 21 eqüinos não verificaram corpúsculos de inclusões em 11 animais $(53 \%)$, porém ressaltam que cinco foram submetidos à eutanásia no $3^{\circ}$ dia após o aparecimento dos sintomas. 
Segundo TRIMARCHI e SMITH (2002) amostras de mais de uma área do SNC podem aumentar a sensibilidade e a segurança do método diagnóstico, especialmente nos animais que são submetidos à eutanásia precocemente no curso clínico da raiva.

No presente estudo não foram observadas diferenças entre a concentração de antígeno viral e a condição de morte do animal (natural ou submetido à eutanásia), provavelmente porque os animais foram submetido à eutanásia na fase de paralasia, onde o comprometimento do sistema nervoso já era grande, pois esta fase ocorre, em geral, 12-24 horas antes da morte do animal.

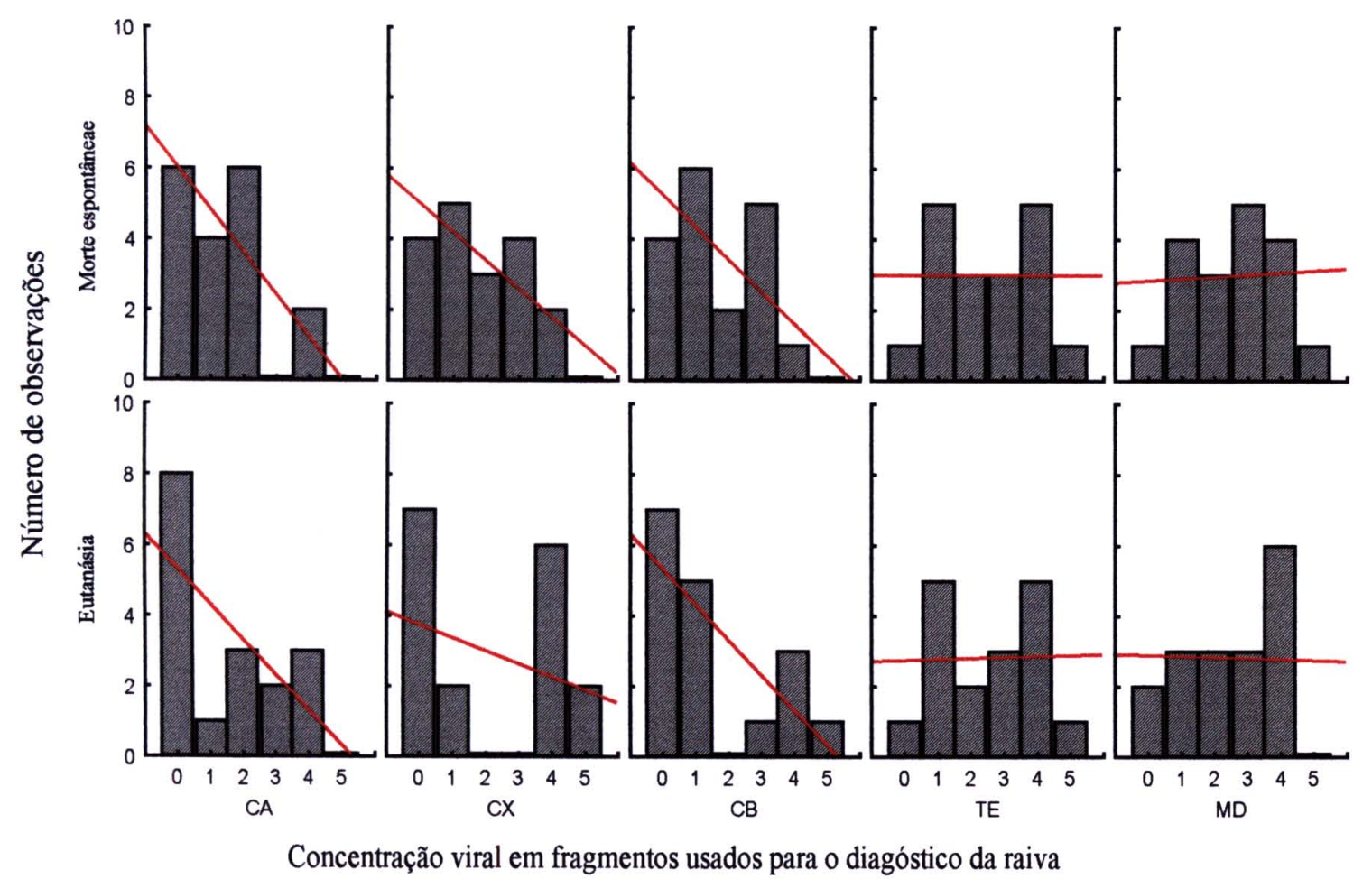

FIGURA 11 - Freqüências de observação para classes de concentrações virais e fragmentos do SNC de 35 eqüídeos, sendo que 18 tiveram óbito natural e 17 foram submetidos à eutanásia. São Paulo, 2000 - 2003. 


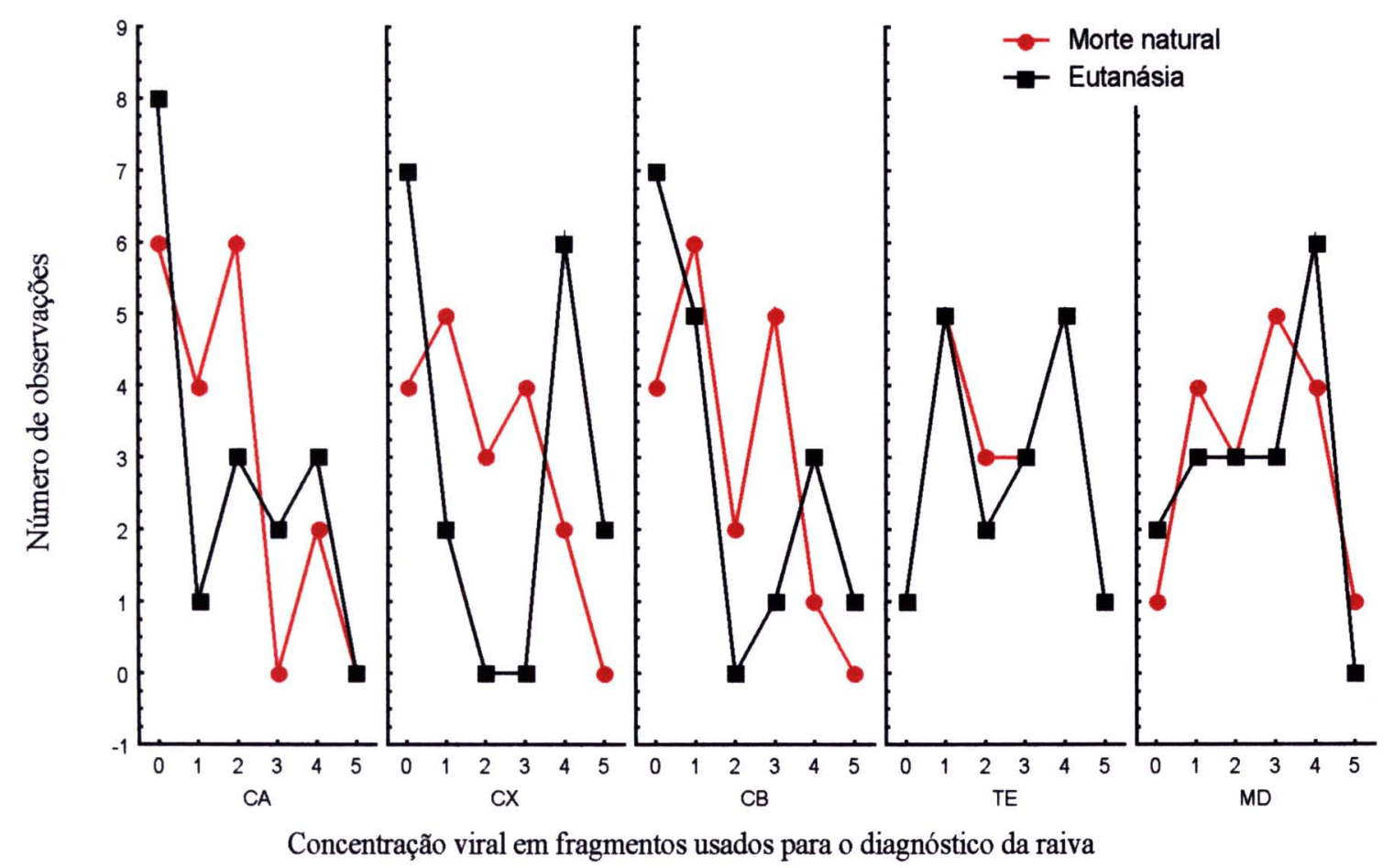

Figura 12. Variação das freqüências experimentais obtidas para diferentes classes de concentrações virais $(0-5)$, comparadas entre fragmentos usados para o diagnóstico da raiva provenientes de 35 eqǘdeos, sendo que 18 tiveram óbito natural e 17 foram submetidos à eutanásia. São Paulo, 2000 - 2003.

$(\mathrm{CA}=$ Corno de Amon; $\mathrm{CX}=\mathrm{Córtex} ; \mathrm{CB}=$ Cerebelo; $\mathrm{TE}=$ Tronco encefálico; $\mathrm{MD}=$ Medula $)$.

\subsection{Análise da prova para isolamento viral}

Em relação ao isolamento viral em camundongos e à existência de diferenças entre as taxas de mortalidade provocada pelo vírus presente nos diferentes fragmentos do SNC, a hipótese testada é a de que diferentes fragmentos utilizados no diagnóstico da doença podem produzir interpretações distintas, baseadas em diferentes taxas de mortalidade em camundongos . 
A Figura 13 mostra as diferenças na proporção de camundongos mortos inoculados com suspensões preparadas a partir dos diferentes fragmentos do SNC.

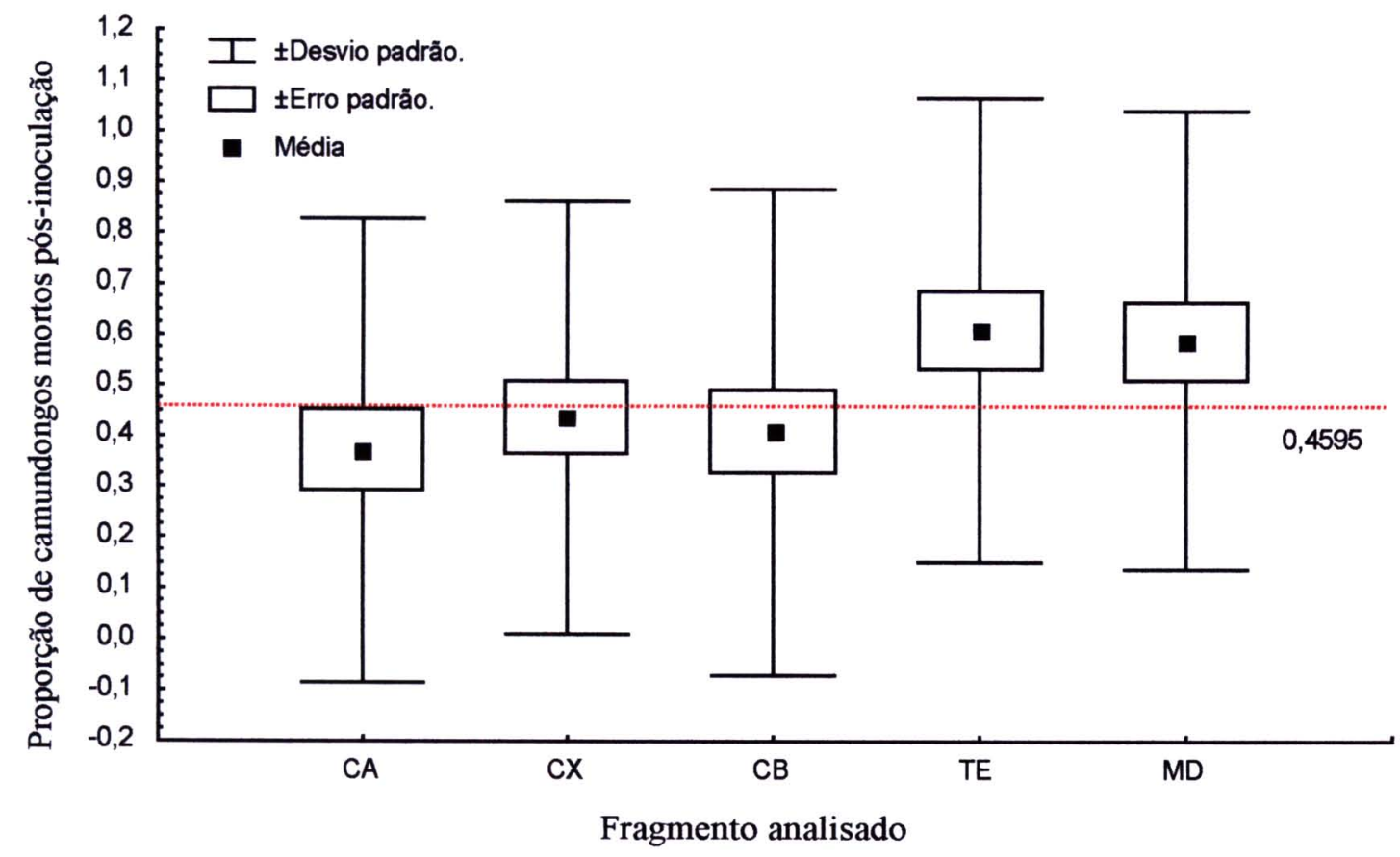

Figura 13 -. Variação da mortalidade de camundongos pós-inoculação com suspensões obtidas a partir de diferentes fragmentos do sistema nervoso de 33 eqüídeos. A linha pontilhada em vermelho indica a proporção média entre todos os fragmentos. São Paulo, $2000-2003$.

$\mathrm{CA}=$ Corno de Amon, $\mathrm{CX}=$ Córtex, $\mathrm{CB}=$ Cerebelo, $\mathrm{TE}=$ Tronco encefálico e $\mathrm{MD}=$ Medula

Pela análise, não existem diferenças significativas do número de camundongos mortos, após a inoculação com suspensões virais obtidas a partir de diferentes fragmentos do SNC $\left(F_{(4,160)}=1,8859 ; p=0,1154\right)$. Apesar de não se constatarem diferenças significativas para o fator analisado, verifica-se uma tendência à maior mortalidade de camundongos 
quando estes foram inoculados com suspensões obtidas a partir do tronco encefálico (TE) ou da medula (MD), como pode ser observado na figura 14.

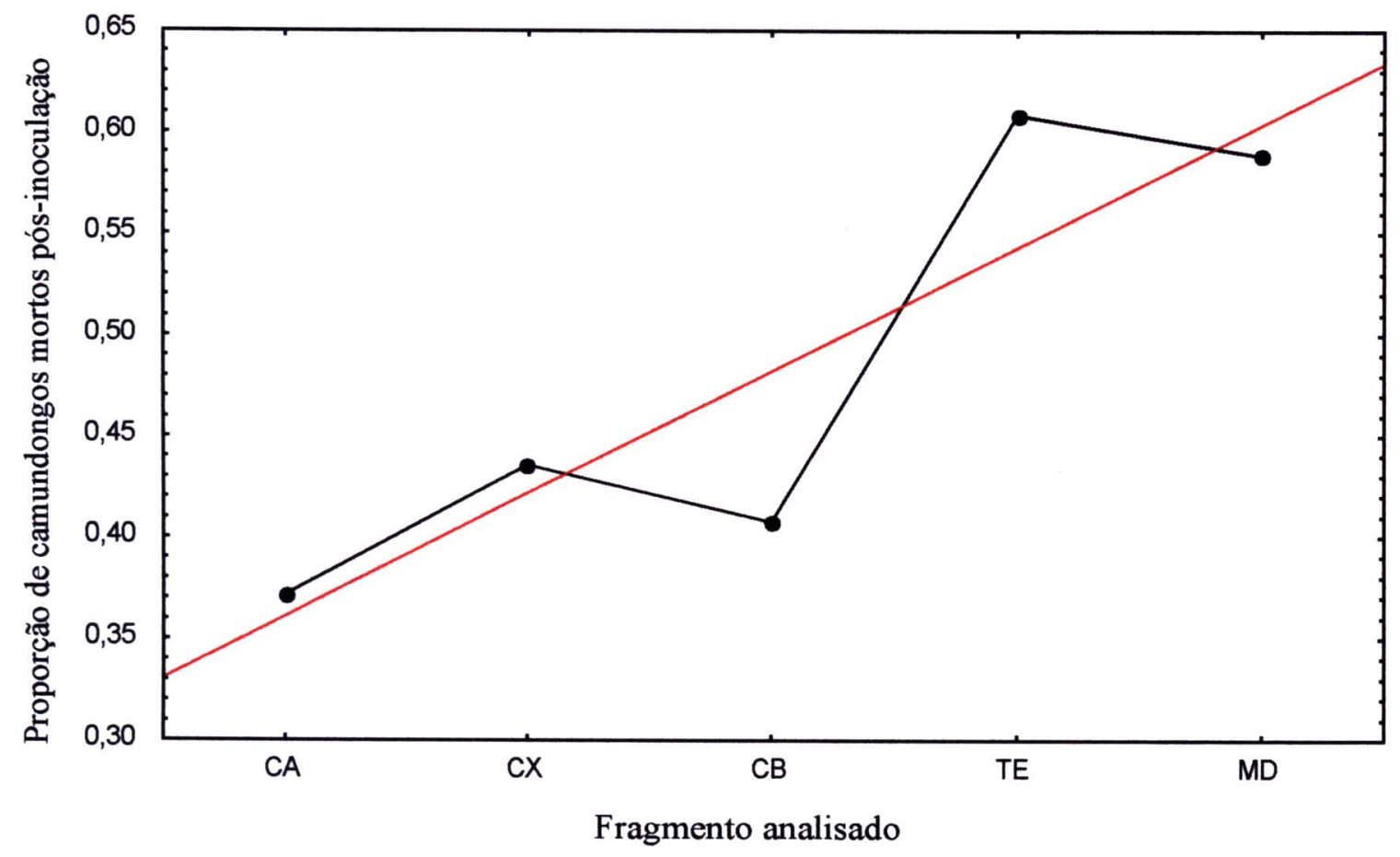

Figura 14 - Tendência de variação da mortalidade de camundongos pós-inoculação com suspensões obtidas a partir de diferentes fragmentos do sistema nervoso de 33 eqüídeos. A linha vermelha representa a tendência central existente no conjunto de dados. São Paulo, $2000-2003$.

$\mathrm{CA}=$ Corno de Amon, $\mathrm{CX}=$ Córtex, $\mathrm{CB}=$ Cerebelo, $\mathrm{TE}=$ Tronco encefálico e $\mathrm{MD}=$ Medula

Considerando que a inoculação intracerebral em camundongos para o isolamento viral é o teste mais sensível e que mínimas concentrações de vírus podem se replicar nestes animais, era de se esperar que não fossem encontradas diferenças significativas entre a 
mortalidade para os diferentes fragmentos, muito embora haja uma nítida tendência de maior mortalidade nos camundongos inoculados com TE e MD.

\subsection{Análise da prova para isolamento viral e histórico de vacinação}

Para verificar se o fato de o animal estar vacinado ou não pode influenciar as taxas de mortalidade em camundongos inoculados com suspensões preparadas a partir de distintos fragmentos do SNC, realizou-se a análise de variância de dois fatores. Apesar de não terem sido encontradas diferenças significativas no teste anterior (One-Way ANOVA), esta nova hipótese é justificada pelo fato de o procedimento de vacinação poder estar "mascarando" os resultados, uma vez que os fragmentos dos diferentes animais foram analisados conjuntamente, sem levar em conta um aspecto importante que é o histórico de vacinação desses animais. Para tanto, recorreu-se à Análise de Variância de Dois Fatores (Two-Way ANOVA), determinando-se como primeiro fator a vacinação ou não do animal e, como segundo fator, os diferentes fragmentos do SNC. Esta é uma maneira de verificar se a vacinação do animal é ou não um fator importante que pode interferir no diagnóstico da raiva.

$\mathrm{O}$ experimento também foi baseado em prova para o isolamento viral, seguindo-se exatamente o mesmo procedimento anterior, mas com um número amostral diferente do teste anterior ( $n=30$ eqüídeos), pois contempla apenas aqueles animais que detêm históricos de vacinação conhecidos.

A figura 15 apresenta a variação de taxas de mortalidade de camundongos inoculados com suspensões preparadas a partir dos diferentes fragmentos do SNC de 30 eqüídeos com histórico de vacinação. Pela análise, não existem diferenças significativas do 
número de camundongos mortos, inoculados com extratos virais obtidos a partir de diferentes partes do Sistema Nervoso (CA, CX, CB, TE e MD) de eqüídeos, tanto para animais vacinados quanto não vacinados.

Após proceder ao teste, verificou-se que não existem diferenças significativas para prova biológica, entre animais vacinados e não vacinados $\left(F_{(1,140)}=1,346 ; p=0,248\right)$, fragmentos do $\operatorname{SNC}\left(F_{(4,140)}=2,086 ; p=0,086\right)$ e mesmo entre a interação destes dois fatores $\left(F_{(4,140)}=0,600 ; p=0,663\right)$.
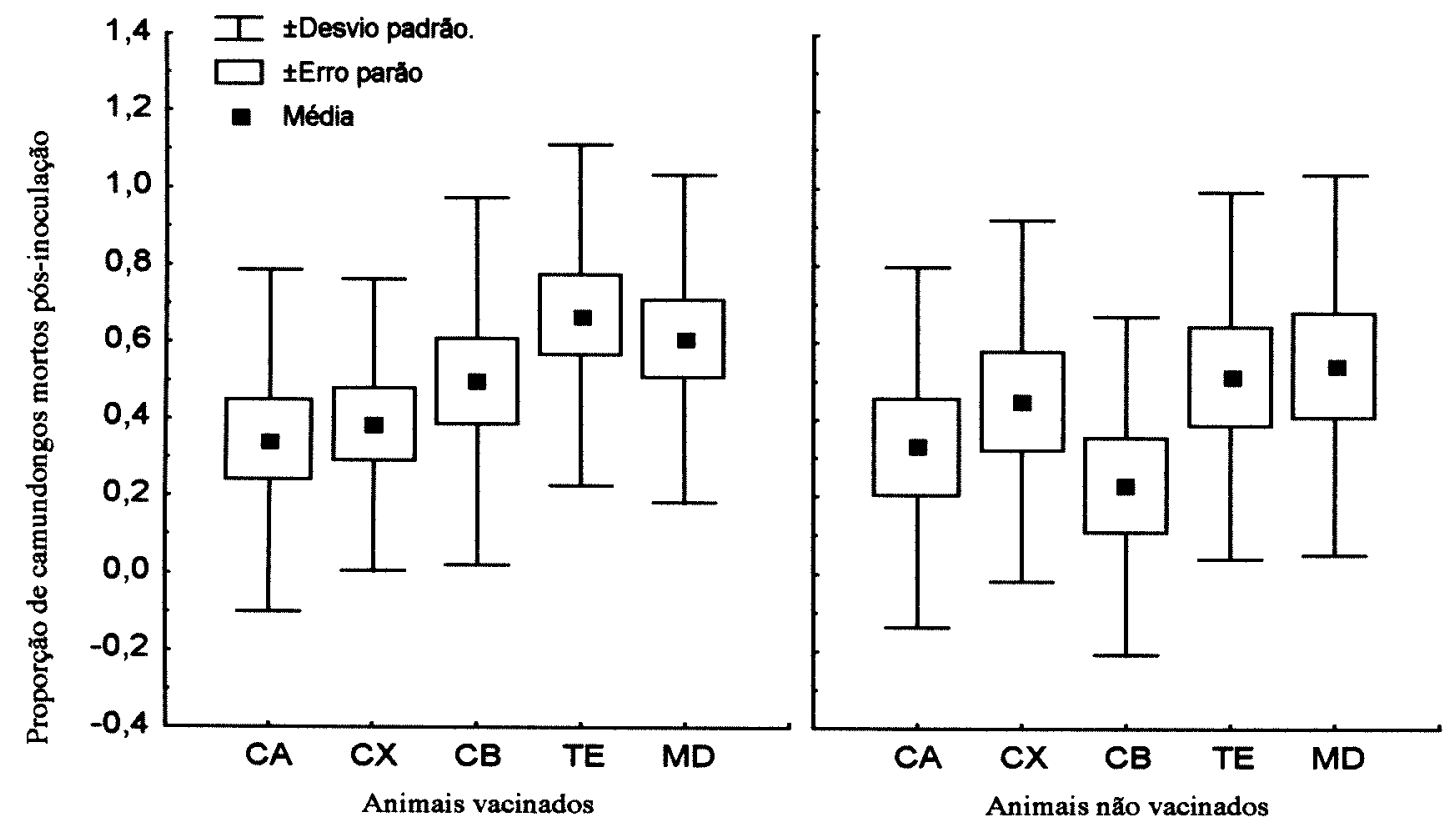

Figura 15 - Variação da mortalidade de camundongos pós-inoculação com suspensões obtidas a partir de diferentes fragmentos do sistema nervoso de 30 eqüídeos com histórico de vacinação ( $n_{1}=17$ vacinados; $n_{2}=13$ não vacinados). São Paulo, $2000-2003$.

$\mathrm{CA}=$ Como de Amon, $\mathrm{CX}=$ Córtex, $\mathrm{CB}=$ Cerebelo, $\mathrm{TE}=$ Tronco encefálico e $\mathrm{MD}=$ Medula 


\subsection{Análise da prova para isolamento viral e tipo de óbito}

A análise de variância de dois fatores também foi utilizada para verificar se existem diferenças entre as taxas de mortalidade dos camundongos inoculados com suspensões de diferentes fragmentos do SNC, considerando o tipo de óbito do animal (eutanásia ou óbito natural). Embora não tenham sido detectadas diferenças significativas nos testes anteriores, esta terceira hipótese se justifica pelo fato de que, nos animais submetidos à eutanásia, houve impedimento da evolução natural da doença e este fato poder interferir nos resultados das taxas de mortalidade da inoculação das suspensões obtidas a partir dos diferentes fragmentos do SNC.

A figura 16 apresenta os resultados das variações das taxas de mortalidade de camundongos inoculados com suspensões obtidas com diferentes fragmentos do SNC de 33 eqüídeos que morreram naturalmente, ou então que foram submetidos ao sacrificio após aparecimento dos sintomas de raiva. De acordo com a análise (para variâncias homogêneas, Levene, $\left.F_{(9,155)}=1,564 ; p=0,131\right)$, não existe diferença entre a porcentagem de camundongos mortos pós-inoculação com suspensões obtidas a partir do SNC de animais submetidos à eutanásia $\left(F_{(1,155)}=0,529 ; p=0,468\right)$, mesmo considerando-se os diferentes fragmentos usados no diagnóstico $\left(F_{(4,155)}=1,851 ; p=0,122\right)$. A interação entre os dois fatores também não mostrou diferenças significativas $\left(F_{(4,155)}=0,117 ; p=0,976\right)$, reforçando a idéia de que ambos os fatores não resultam em diferenças, mesmo se considerados caso a caso. 

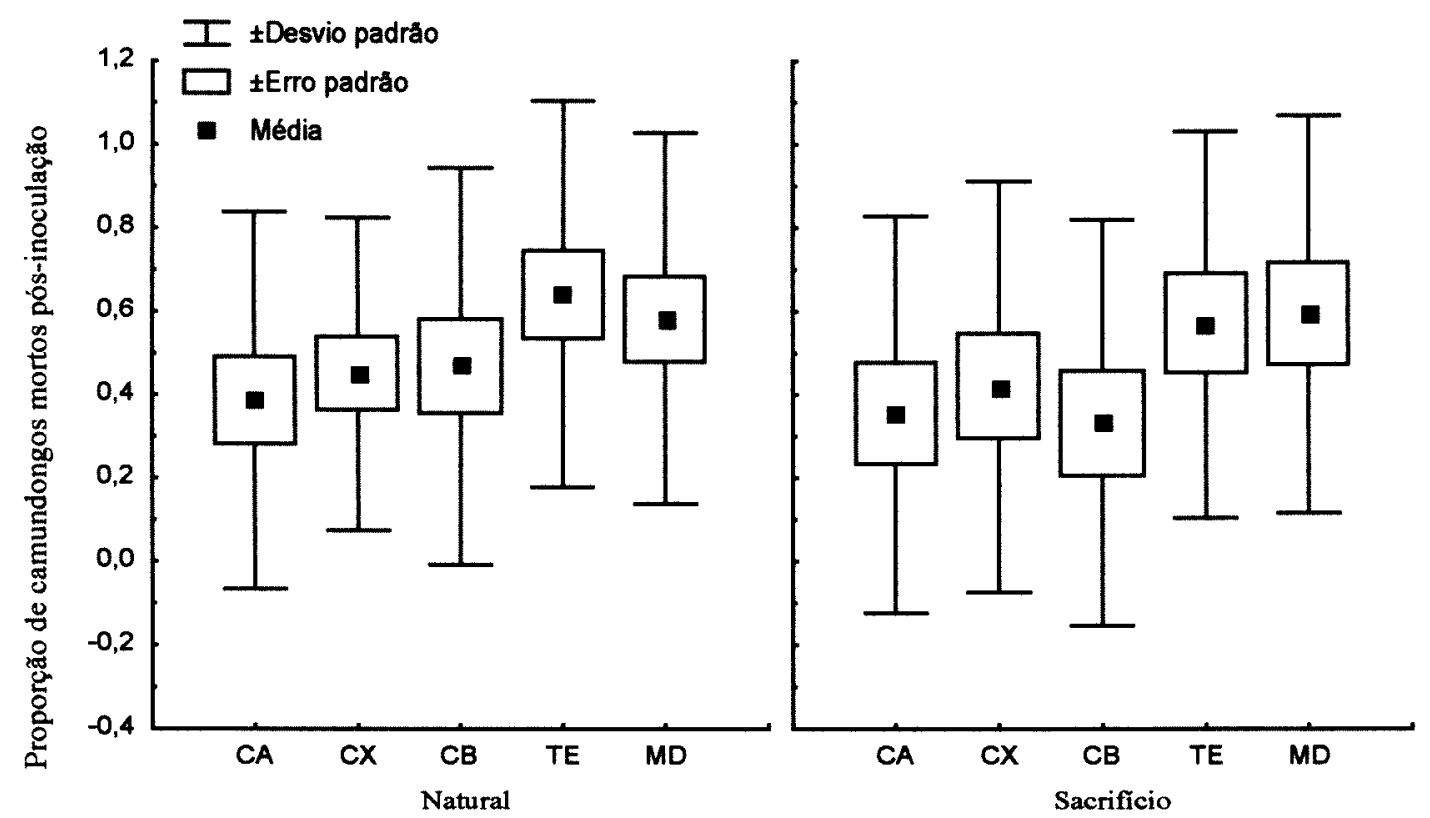

Tipo de óbito

Figura 16 - Variação da mortalidade de camundongos pós-inoculação com supensões obtidas a partir dos diferentes fragmentos do SNC de 33 eqüídeos que morreram naturalmente ou que foram submetidos à eutanásia após aparecimento dos sintomas. $\left(n_{1}=18\right.$ mortos naturalmente; $n_{2}=15$ submetidos à eutanásia).

Da mesma forma que não houve dependência da concentração antigênica nos diferentes fragmentos analisados pela IFD, não houve diferenças nas taxas de mortalidade de camundongos inoculados com suspensões preparadas a partir dos diferentes fragmentos, quando analisados animais vacinados e não vacinados, e animais que morreram naturalmente ou foram submetidos à eutanásia

Ressalta-se que os dados obtidos sobre a vacinação não são suficientes para que se elabore uma análise melhor e que os animais foram submetidos à eutanásia na fase de paralisia. 


\subsection{Isolamento viral a partir de glândulas salivares}

Segundo BAER (1991), bovinos com raiva paralítica podem excretar vírus pelas glândulas lacrimais e salivares antes do aparecimento de sinais clínicos. Em bovinos infectados experimentalmente o vírus foi encontrado em glândulas parótidas e submaxilares, sendo que os títulos virais foram mais elevados nas glândulas parótidas, especialmente em infeç̧ões experimentais com vírus isolados de morcego hematófago (Desmodus rotundus). Johnson (1967), citado por SILVA e SILVA (1973), considerou que a possibilidade do vírus se disseminar nas glândulas salivares variava de acordo com as diferentes espécies de hospedeiros.

O fato de o vírus estar presente em alguns tecidos e fluidos, antes do início dos sintomas, possui grande importância para a Saúde Pública (CHARLTON 1988). Este mesmo autor refere que animais infectados naturalmente apresentam altas taxas de infecção de vírus nas glândulas salivares, principalmente, nas submandibulares: bovino (80\%), gato (87\%), raposa (100\%) e gambá $(76 \%)$. Geralmente, as glândulas sumandibulares têm alto título viral; as parótidas possuem título intermediário e as sublinguais baixos títulos.

VEERARAGHAVAN e col. (1958), ao pesquisarem vírus da raiva em cães suspeitos de terem sido infectados, confirmaram a presença de vírus nas glândulas submandibulares de $36(59 \%)$ de 61 cães cuja doença foi confirmada laboratorialmente. SILVA e SILVA (1973), também estudando raiva canina isolaram vírus da raiva de glândulas submandibulares, sem, no entanto, isolarem de fragmentos do encéfalo.

DELPIETRO e col. (2001), ao estudar 87 bovinos infectados naturalmente, com o vírus do Desmodus rotundus, isoloram vírus da glândula salivar de $4,6 \%$ e da saliva de $1,6 \%$ dos animais, trabalhando com número semelhante de glândulas submandibulares e parótidas. 
SILVA e col. (1974), ao pesquisarem vírus em glândulas salivares de eqüinos positivos para raiva, sugerem que na infecção rábica, na espécie eqüina, o vírus não se propaga para as glândulas salivares. Em bovinos estes autores encontraram vírus nas glândulas salivares de 15 dos 22 animais estudados $(68,2 \%)$.

Embora haja muitos relatos de isolamento de vírus em glândulas salivares de várias espécies animais, nada foi encontrado em eqüídeos .

Conforme descrito no item Material e Métodos, neste trabalho pesquisou-se vírus da raiva em glândulas salivares de 50 cavalos, tendo sido coletadas pelo menos uma de cada animal. Embora da maioria deles (30) tenham sido coletadas glândulas parótidas e submandibulares, não foi realizada análise estatística visto que apenas dois animais (4\%) apresentaram positividade. De ambos haviam sido coletadas uma glândula parótida e uma glândula submandibular. Um dos animais apresentou positividade na glândula parótida e submandibular e o outro apenas na parótida.

As condições de animal vacinado ou não e com morte natural e submetidos à eutanásia não exerceram, aparentemente, nenhuma influência, visto que um deles (parótida e sumandibular positivas) apresentava histórico de vacinação e teve morte natural, e o outro (parótida positiva) não possuia histórico de vacinação e foi submetido à eutanásia. Os dois animais apresentaram positividade, pela IFD, nos cinco fragmentos, e apenas um apresentou mortalidade em camundongos inoculados com todos os fragmentos e o outro mortalidade em camundongos inoculados apenas com CX, TE e MD.

O fato de, os animais positivos para glândulas salivares terem apresentado positividade em todos os fragmentos, não significa que animais que apresentaram TE e MD positivos não podem apresentar vírus nas glândulas, tendo em vista, principalmente, a simultaneidade dos fluxos centrípeto e centrífugo (BOURHY 1992). 


\subsection{Tratamento humano}

A raiva eqüina é considerada uma doença rara, especialmente no continente europeu (WEST 1985; DOQUET 1990). Nos Estados Unidos e Canadá há relatos de cerca de um caso ao ano (RAPP 1969; HAMIR e col. 1992; GREEN e col. 1992; WRIGHT 2001), porém outro trabalho menciona cerca de 50 casos de raiva em eqüinos nos últimos anos (KREBS e col 2002). Nestes países os principais animais transmissores da raiva eqüina são o gambá, a raposa e o guaxinim, sendo que o potencial de risco humano faz com que a discussão de suas causas torne-se importante (NIEZGODA e col. 2002).

Muito embora a frequência dos casos de raiva eqüina seja considerada muito rara na literatura mundial, esta não é a situação do Brasil e, em particular, do Estado de São Paulo.

A transmissão da raiva de eqüinos para o homem é mais rara ainda tendo sido relatado um caso na Etiópia (FEKADU 1982). No Brasil, há dois relatos de casos humanos de raiva transmitidos por eqüídeos (ARAUJO 2002).

A exposição humana a eqüídeos infectados com o vírus da raiva é importante, considerando o número de pessoas envolvidas com estes animais, seja por razão de trabalho ou por recreação.

Relatos de exposição de humanos a bovinos e eqüinos raivosos têm sido feitos, especialmente em casos de raiva furiosa, demonstrando o risco de exposição de humanos (HAHN 1982). GREEN (1993) ao estudar diferentes aspectos da raiva eqüina (epidemiologia, sinais clínicos, patogenia e diagnóstico) considerou que a doença, embora rara na América do Norte, é importante na América Central e América do Sul, e que o risco humano, nestas regiões, é significante. 
MARLER e col. (1979) descreveram um caso clínico de raiva em eqüino, no qual 25 pessoas tiveram contato ( 20 estudantes de veterinária e 5 profissionais veterinários).

FEDER e col. (1998) relataram um caso de raiva em um ponei, ocorrido em 1993 (Connecticut/EUA) em uma fazenda que recebia a visita de cerca de 100 pessoas ao dia. A amostra isolada foi compativel com as amostras de guaxinim. A partir do diagnóstico positivo foi realizada uma chamada, através da mídia, e identificaram 67 pessoas que tiveram contato com o ponei, nos 14 dias anteriores ao óbito. Destes, 6 eram moradores da fazenda e veterinários, e 61 eram visitantes, sendo 45 (74\%) crianças, com idade inferior a 12 anos. Por terem tido contato com a saliva do animal, $54 \%$ das pessoas foram tratadas com soro homólogo e vacinação. Os autores sugerem a necessidade de vacinação de animais que têm, rotineiramente, contato com o público.

Nesta presente pesquisa verificou-se que 101 pessoas tiveram contato com 35 cavalos, dos quais se obteve este tipo de informação.

Deve-se considerar, também, a gravidade das lesões provocadas por agressões animais, em particular dos eqüídeos conforme citam GOMES e col. 2000. Os autores relatam que $80 \%$ destas agressões por animais ocorrem em crianças e $20 \%$ provocadas por eqüídeos

SMITH (1996) menciona que muitas das recomendações para o diagnóstico da raiva animal e tratamento de pessoas expostas ao risco são baseadas na observação que glândulas salivares ricas em vírus, e outros tecidos periféricos, somente ocorrem após replicação no SNC e que a excreção de vírus na saliva é esporádica. Segundo o autor, a ausência de antígeno rábico no cérebro de um animal, submetido a IFD exclui a presença de vírus na 
saliva, o risco de transmissão pela mordedura e a necessidade de tatamento anti-rábico. Os fragmentos recomendados pelo pesquisador são: medula, cerebelo e hipocampo.

$\mathrm{Na}$ Inglaterra, embora a raiva eqüina seja raríssima, há a preocupação sobre a possibilidade da infecção em eqüinos provocar conseqüências à saúde pública (FULLER 1984).

O diagnóstico laboratorial da raiva, embora faça uso de técnicas de reconhecida sensibilidade e especificidade, não apresenta os mesmos resultados quando a amostra é de origem eqüina, conforme resultados apresentados por diversos pesquisadores de diferentes países (SILVA e col. 1974; GREEN e col. 1992; PEIXOTO e col. 2000; BINGHAM e VAN DER MERWE 2002). Estes autores fazem referência, também, às diferenças entre as amostras que determinam as duas formas da raiva: paralítica e furiosa, que poderiam ocasionar as diferenças observadas.

Considerando que para o tratamento profilático anti-rábico humano a IFD é um fator determinante, pela sua rapidez, e que a sensibilidade desta técnica depende do fragmento que é encaminhado ao laboratório, torna-se imprescindível que se estabeleçam normas rígidas para a remessa de amostras de eqüídeos, suspeitos de estarem infectados pelo vírus da raiva e que, frequentemente, têm contato com humanos.

Na presente pesquisa, a identificação de vírus nas glândulas salivares de eqüídeos, infectados naturalmente pelo morcego hematófago - Desmodus rotundus - pela primeira vez, torna a ocorrência da raiva nestes animais, em nosso meio, não só uma questão com forte impacto econômico, mas também um grave problema de saúde pública. 


\section{CONCLUSÕES}

1. As técnicas de IFD e IVC, quando aplicadas ao diagnóstico da raiva de eqüídeos, e analisadas conjuntamente, apresentaram sensibilidade igual para TE e MD, e superiores aos demais fragmentos avaliados, $\mathrm{CA}, \mathrm{CX}$ e $\mathrm{CB}$;

2. O TE e MD foram os melhores fragmentos para o diagnóstico laboratorial, tanto pela IFD como pela IVC;

3. As condições de vacinação ou não e óbito natural ou eutanásia, não interferiram no resultado do diagnóstico laboratorial, considerados os diferentes fragmentos, ressaltando que a eutanásia, quando aplicada, foi executada na fase paralítica (terminal);

4. Os animais que apresentaram vírus rábico na glândula salivar foram positivos para todos os fragmentos do SNC pela técnica de IFD;

5. Para a definição do risco potencial de humanos e decisão sobre o tratamento profilático pós-exposição, é imprescindível que se conheçam os fragmentos encaminhados para o laboratório de diagnóstico e o resultado pela IFD;

6. Para o diagnóstico da raiva de equí́deos devem ser encaminhados para o laboratório fragmentos do TE e MD. 
Acha PN. Epidemiology of paralytic bovine rabeis and bat rabies. Bull Off Int Epizoot. $1967 ; 67: 343-82$.

Acha MA, Szyfres B. Zoonosis y enfermedades transmisibles comunes al hombre y a los animales. $2^{\mathrm{a}}$ ed.Washington (DC): Organización Panamericana de la Salud; 1986.(OPAS - Publicación Cientifica, 503).

Arai YT, Kuzmin IV, Kameoka Y, Botvinkin AD. New Lyssavirus genotype from the lesser mouse-eared bat (Myotis blythi), Kyrghystan. Emer Infect Dis. 2003; 9:333-37.

Araujo FA. Raiva humana no Brasil, 1992 - 2001. Belo Horizonte 2002 [Dissertação de mestrado - Escola de Veterinária - Univ Fed Minas Gerais].

Badilla X, Herra VP, Quirós L, Morice A, Jiménez E, Sáenz E, Salazar F,Fernández R, Orciari L, Yager P, Whitfield S, Ruprecht CE. Human rabies: a reemerging disease in Costa Rica? Emer Infect Dis. 2003; 9:721-723.

Baer GM. Bovine paralytic rabies and rabies in the vampire bat. In: The Natural History of Rabies. Vol 2 Academic Press, New York: 1975.p.389-400

Baer GM, Yanger PA. A mouse for post-exposure rabies prophylaxis: the comparative efficacy of two vaccines and of antiserum administration. J Gen Virol. 1977; 36:51-8.

Baer GM, Lentz TL. Rabies pathogenesis to the central nervous system: The Natural History of Rabies. $2^{\text {nd }}$ ed. Boca Ratón: CRC Press; 1991.p. 106-1 18.

Baer GM. Vampire bat and bovine paralytic rabies: The Natural History of Rabies. $2^{\text {nd }}$ ed.Boca Ratón: CRC Press; 1991. p.390-400.

Beneson AS, editor. Manual para el control de las enfermedades transmisibles.

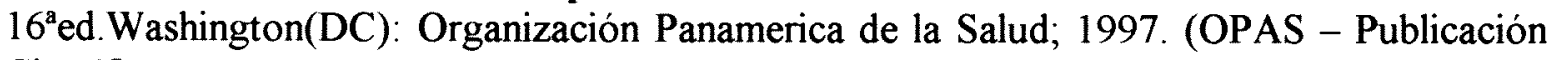
Científica, 564).

Bingham J, Van Der Merwe M. Distribution of rabies antigen in infected brain material: determining the reliability of different regions of the brain for the rabies fluorescent antibody test. J Virol Methods. 2002; 101:85-94.

Bourhy H, Sureau P, Tordo N. From rabies to rabies-related viruses. Vet Microbiol. 1990; $23: 115-28$.

Bourhy $H$. Diversité du genre Lyssavirus: Consequences diagnostiques, epidemiologiques et vaccinales.Paris; 1992 [Docteur de L'Universite - Universite Pierre et Marie Curie].

* Guia de Apresentação de Teses. Faculdade de Saúde Pública-USP 
Bourhy H, Kissi B, Lafon M, Sacramento D, Tordo N. Antigenic and molecular characterization of bat rabies vírus in Europe. J Clin Microbiol. 1992; 30:2419-26.

Bourhy H, Kissi B, Tordo N. Taxonomy and evolutionary studies os Lyssaviruses with special reference to Africa. Onderstepoort J Vet Res. 1993; 60:277-82.

Bryceson ADM, Greenwood BM, Warrell DA. Demonstration during life of rabies antigen in humans. J Infect Dis. 1975; 131:71-4.

Burnes JM, Paz AM, Solares AC, Méndez GV, Hernández AR, Valenzuela AA, Ginez VZ. Técnicas comparativas para el diagnóstico de rabia y su incidencia en Tamaulipas en 1987. Rev Lat amer Microbiol. 1991; 33:209-17.

Carini A. Sur une grande épizootie de rage. Annales de L'Institut Pasteur 1911; 25: 84346.

Carneiro V. As epizootias de raiva na América e o papel dos morcegos hematófagos. Arq do Inst Biol. 1936; 7:273-321.

Carrieri ML, Favoretto SR, Carnieli Jr, P, Peixoto ZMP, Achkar S, Paiva JPRC, Kotait I. Canine and feline rabies in the Espírito Santo do Pinhal city, São Paulo, transmitted by vampire bat. In: Virus: reviews and research/Sociedade Brasileira de Virologia; 2001 nov 25-28; Caldas Novas. vol 6 supl 1.p.176.

Ceccaldi PE, Gillet JP, Tsiang H. Inhibition of the transport of rabies virus in the central nervous system. J Neuropathol Exp Neurol. 1993; 48:620-30.

Celis E, Milles R, Wiktor T, Dietzschold B, Koprowski H. Isolation and characterization of human $\mathrm{T}$ cell lines clones reactive to rabies virus: antigen specificity and production of interferon gamma. J Immunol. 1986; 136:692-97.

Clark HF. Rabies viruses increase in virulence when propagated in neuroblastoma cell culture. Science. 1978; 199:1072-75.

Constantine DG. Rabies transmission by nonbite route. Publ Health Rep. 1962; 77:287-89.

Coons $\mathrm{AH}$ e Kaplan MH. Localization of antigen in tissue cells II. Improvements in a method for the detection of antigen by means of fluorescent antibody. J Exp Med. 1950 91:1-13

Correa-Giron EP, Allen R, Sulkin SE. The infectivity and pathogenesis of rabies virus administered orally. Amer J Epidemiol. 1970; 91:203-15.

Costa WA, Ávila CA, Valentine EJG, Reichmann MLB, Cunha RS, Guidolin R e col. Profilaxia da raiva humana. $2^{\mathrm{a}}$ ed. São Paulo; 2001 (Instituto Pasteur Manuais, 4). 
Chamelet ELB. Infectividade da saliva e glândulas salivares submaxilar e parótida de cães raivosos naturalmente infectados. São Paulo; 1986. [Dissertação de Mestrado Faculdade de Saúde Pública].

Charlton KM. The pathogenesis of rabies. In:Campbell JB \& Charlton KM. Rabies. Boston: Kluwer Academic Publishers; 1988. p.1001-150.

Childs JE. Epidemiology. In:Jackson AC, Wunner W. Rabies. San Diego:Academic Press; 2002.p.113-62.

Daniel WW. Biostatistics. A foundation for analysis in the health sciences. $6^{\text {th }}$ ed.John Wiley e Sons, 1995, New York 780p.

David D, Yakobson B, Rotenberg D, Dveres N, Davidson I, Stram Y. Rabies virus detection by RT-PCR in decomposed naturally infected brains. Vet Microbiol. 2002; $87: 11-8$

Dean DJ, Abelseth MK, Atanasiu P. The fluorescent antibody test. In:Meslin F-X;Kaplan MM, Koprowski $H$. Laboratory techniques in rabies. $4^{\text {th }}$ ed.Geneva: World Health Organization, 1996. p.88-95.

Delpietro HA, Dhomen FG, Larghi OP, Mena-Segura C, Abramo I. Monoclonal antibody characterization of rabies virus strains isolation in the River Plate Basin. J Vet Med. 1997; 44:477-483.

Delpietro HA, Larghi OP, Russo RG. Virus isolation from saliva and salivary glands of cattle naturally infected with paralytic rabies. Prev Vet Med. 2001; 48: 223-228.

Diaz AM, Papo S, Rodriguez A, Smith JS. Antigenic analysis of rabies-virus isolates from Latin America and the Caribbean. J Vet Med. 1994; 41:153-60.

Dietzschold B, Wiktor TJ, Macfarlan R, Varrichio A. Antigenic structure of rabies virus glycoprotein: ordering and immunological characterization of the large $\mathrm{CNBr}$ clevage fragments. J Virology, 1982; 44:595-602.

Dietzschold B, Wiktor TJ, Wunner WH, Varrichio A. Chemical and immunological analysis of the soluble glycoprotein. Virology 1983; 124:330-37.

Dietzschold B, Tollis M, Rupprecht CE, Cellis E, Koprowski H. Antigenic variation in rabies and rabies-related viruses: cross-protection independent of the glycoprotein-mediated virus neutralizing antibody. J Infect Dis. 1987; 156: 815-22.

Doquet J. Cas de rage équine correspondant a l'analyse $n^{\circ} 31973$ du Centre National D'Etudes sur la rage. Revue Méd vét. 1990; 131: 393-96.

Favi M, Mattos CA, Yung V, Chala E, Lopez LR, Mattos CC. First case of human rabies in Chile caused by an insectivorous bat virus variant. Emerg Infect Dis. 2002; 8: 79-81. 
Favi M, Nina A, Yung V, Fernández J. Characterization of rabies virus isolates in Bolivia. Virus Research. 2003; 97: 135-140.

Favoretto SR, Carrieri ML, Cunha SEM, Aguiar EAC, Silva LHQ, Sodré MM, Souza MCM, Kotait I. Antigenic typing of Brazilian rabies vírus samples isolated from animals and humans, 1989-2000. Rev Inst Med trop S Paulo. 2002; 44: 91-5.

Feder HM, Nelson RS, Cartter ML, Sadre I. Rabies prophylaxis following the feeding of a rabid pony. Clin Pediatr. 1998; 37: 477-81.

Fekadu M. Rabies in Ethiopia. Am J Epidemiol. 1982; 115: 266-73

Fenner F, Bachmann PA, Gibbs EPJ, Murphy FA, Studdent MJ, White DO. Rhabdoviridae. In: Virologia Veterinária. Zaragoza-Espanha: Acribia; 1992. p.551-62.

Fermaglich DH, Horohov DW. The effect of aging on immune responses. Vet Clin North Am Equine Pract. 2002; 18:621-30.

Fishbein DB. Rabies in human. In:Baer GM. The Natural History of Rabies. $2^{\text {nd }}$ ed.Boca Ratón: CRC Press; 1991.p.519-43.

Flamand A, Delagneau JF. Transcriptional mapping of rabies virus in vivo. J Virol 1978; 28: $518-23$.

Flamand A, Wiktor TJ, Koprowski H, Use of hybridoma monoclonal antibodies in the detection of antigenic differences between rabies and rabies related virus protein. I The nucleocapsid protein. J Gen Virol. 1980a; 48: 97-104.

Flamand A, Wiktor TJ, Koprowski H, Use of hybridoma monoclonal antibodies in the detection of antigenic differences between rabies and rabies related virus protein. II The glycoprotein. J Gen Virol. 1980b; 48: 105-9.

Fuller JE. A case of equine rabies. New Engl J Med. 1984; 310: 525-6.

Galtier V. Les injections de virus rabique dans le torrent circulatoir ne provoquent pas l'eclosion de la rage et semble confere l'imunité. Le rage peut etre transmise par l'ingestion de la matiere rabique. C R Acad Sci. 1881; 93 : 284-95.

Galtier, V. Etudes sur la rage. C R Acad Sci 1879; 89:444-46.

Gaudin Y, Ruigrok RW, Tuffereau C, Knossow M, Flamand A. Rabies virus glycoprotein is a trimer. Virology, 1992; 187: 627-632. 
Germano PML, Miguel O, Chamelet ELB, Morita, LTMS. Estudo comparativo entre as técnicas de coloração de Sellers, imunofluorescência e inoculação em camundongos aplicadas ao diagnóstico laboratorial da raiva canina. Rev Fac Med Vet Zootec Univ $\mathbf{S}$ Paulo. 1977; 14:133-41.

Germano PML, Silva EV, Miguel O, Sureau P. Variantes antigenicas del virus de la rabia aisladas en el nordeste y sudeste del Brasil. Estudio preliminar. Bol Ofic Sanit Panamer. 1990; 108: 39-45.

Goldwasser RA, Kissling RE. Fluorescent antibody staining of street and fixed rabies virus antigens. Proc Soc Exp Biol Med. 1958; 98: 219-23.

Gomes CM, Ribeiro Filho L, Giron AM, Mitre AI, Figieira ERR, Arap S. Genital trauma due to animal bites. J Urology. 2000; 165: 80-3.

Gould AR, Hyatt AD, Lunt R, Kathenbelt JA, Hengstberger S, Blacksell SD Characterization of a novel lyssavirus isolated form Pteropid bats in Australia. Virus Res 1998; 54: 165-87.

Green SL, Smith LL, Vernau W, Beacock SM. Rabies in horses: 21 cases (1970-1990). J Am Vet Med Assoc. 1992; 200: 1133-7.

Green SL. Equine rabies. Vet Clin North Am Equine Pract. 1993; 9:337-47.

Gibbons RV. Cryptogenic rabies, bats, and the question of aerosol transmission. Ann Emerg Med. 2002; 39:528-36.

Hahn DG. A case of equine rabies with human and bovine exposure. Vet Med Small animal clin. $1982 ; 1409-10$.

Hamir NA, Moser G, Rupprecht CE. A five year (1985-1989) retrospective study of equine neurological diseases with special reference to rabies. J Comp Path. 1992; 106:411-21.

Hanna JN, Carney IK, Smith GA, Tannenberg AE, Deverill JE, Botha JA, Serafin IL et al.Australian bat lyssavirus infection: a second human case, with a long incubation period. Med J Aust. 2000; 172: 597-99.

Hass I. Molecular epidemiology of animal virus diseases. J Vet Med. serie B. 1997; 44: 257-272.

Haupt H, Rehaag H. Raiva epizootica nos rebanhos de Santa Catarina, transmitida por morcegos. Bol Soc Bras Med Vet. 1925; 2: 17-47.

Hayashi Y, Mora E, Chandelier EL, Montaño JA, Ohi M. Estudos de proteção cruzada de 24 cepas de vírus rábico isoladas de diferentes espécimes animais no Brasil. Arq Biol Tecnol. 1984; 27: 27-35. 
Hemachudha T, Laothamatas J, Rupprecht CE. Human rabies: a disease of complex neuropathogenetic mechanisms and diagnostic challenges. Lancet Neurol. 2002; 1: 101-9.

Hilfenhaus J, Karges H, Weinmann E, Barth R. Effect of administered human interferon on experimental rabies in monkeys. Infect Immunity. 1975; 11: 1156-58.

Hudson LC, Weinstock D, Jordan T, Bold-Fletches NO. Clinical presentation of experimentally induced rabies in horses. J Vet Med B. 1996; 43:277-85.

Hurst EW, Pawan JL. An outbreak of rabies in Trinidad. Lancet. 1931; 622-28.

Ito FH, Vasconcellos SA, Erbolato EB, Macruz R, Côrtes JA. Rabies virus in different segments of brain and spinal cord of naturally and experimentally infected dogs. Int $\mathbf{J}$ Zoon. 1985; 12: 98-104.

Ito M, Arai YT, Itou T, Sakai T, Ito FH, Takasaki T, Kurane I. Genetic characterization and geographic distribution of rabies virus isolates in Brazil: identification of two reservoirs, dogs and vampire bats. Virology. 2001; 284: 214-22.

Ito M, Itou T, Shoji Y, Sakai T, Ito FH, Arai YT, Takasaki T, Kurane I. Discrimination between dog-related and vampire bat-related rabies viruses in Brasil by strain-specific reverse transcriptase polymerase chain reaction and restriction fragment length polymorphism analysis. J Clin Virol. 2003; 26: 317-30.

Iwasaki Y, Tobita M. Pathology In:Jackson AC, Wunner W. Rabies. San Diego:Academic Press; 2002.p.283-306.

Jackson AC. Rabies In: Nathanson N. Viral Pathogenesis. Philadelphia;Lippincott Willians e Wilkins; 1997.p.575-91.

Jackson AC. Pathogenesis.: Rabies. San Diego:Academic Press; 2002. p.246-274

Johnson N, Selden D, Parsons G, Healy D, Brookes SM, McElhinney LM, Hutson AM, Fooks AR. Isolation of a European bat lyssavirus type 2 from a Daubenton's bat in the United:Kingdom.Vet Rec. 2003; 13:383-7.

Kaplan MM. Safety precautions in handling rabies virus. In: Meslin FX, Kaplan MM, Koproswki $\mathrm{H}$. ed. Laboratory techniques in rabies. $4^{\text {th }}$ ed. Geneva: World Health Organization: 1996 p.3-8.

Kawai A. Transcriptase activity associated with rabies virion. J.Virol. 1977; 24: 826-37.

Keane DP, Little PB. Equine viral encephalomyelitis in Canada: a review of known and potential ?causes. Can Vet J. 1987; 28: 497-504.

King AA, Tuner GS. Rabies: a review. J Comp Pathol. 1993; 108: 1-39. 
King AA. Cell culture of rabies virus. In: In:Meslin F-X;Kaplan MM, Koprowski H. Laboratory techniques in rabies. $4^{\text {th }}$ ed.Geneva: World Health Organization, 1996 p.114130.

Kissling RE. The fluorescent antibody test in rabies. In:Baer GM. The Natural History of Rabies. Academic Press, New York: 1975.p.401-416

Koch FJ, Sagrtz JW, Davidson DE, Lawhaswasdi K. Diagnosis of human rabies by the cornea test. Am J Clin Pathol. 1975; 63: 509-15.

Koprowski H, Mocarelli P, Wiktor TJ. Antibody response in "vitro" to an animal virus: production of rabies neutralizing antibodies by mouse cells in culture. Proc Natl Acad Sci. $1972 ; 69: 2433-36$

Koprowski H. Visit to an ancient curse. Scientific American Science and Medicine. 1995; p. 47-58.

Koprowski H. The mouse inoculation test In: Meslin F-X, Kaplan MM, Koprowski H. ed. Laboratory techniques in rabies $4^{\text {th }}$ ed. Geneva: World Health Organization: 1996 p.8087.

Koprowski H, Dietzschold B. Rabies: Lessons from the past and a glimpse into the future. In: Peterson PK ed. In defense of the brain: current concepts in the immunopathogenesis and clinical aspects of CNS infections. Massachusetts: Blackwell Science Inc; 1998. p. 239-57.

Kotait I, Gonçalves CA, Peres NF, Souza MCA, Targueta MC. Controle da raiva dos herbívoros. São Paulo; 1998 (Instituto Pasteur Manuais, 1).

Kotait I. Controle da raiva dos herbívoros-Vacinação. Past In Pasteur Informa 2001; 6 p.3.

Kotait I, Favoretto SR, Carrieri ML, Takaoka NY. Raiva humana causada pela variante-3 Desmodus rotundus - no Estado de São Paulo. In: Anais da XIII Reunión Internacional sobre avances en la investigación y control de la rabia em las Américas; 2002 nov 3-8; Cidade de Oaxaca (MX).Cidade de Oaxaca: 2002.p.35

Kotait I. Epidemiological surveillance in wildlife rabies: impact on public health. In: Virus: reviews and research/Sociedade Brasileira de Virologia; 2003 set 14-17; Florianópolis. vol 8 supl 1.p.37

Krebs JW, Smith JS, Rupprecht CE, Childs JE. Mammalian reservoirs and epidemiology of rabies diagnosed in human beings in the United States, 1981-1998. Ann NY Acad Sci. 2000; 916: 345-52.

Krebs JW, Noll HR, Rupprecht CE, Childs JE. Rabies surveillance in the United States during 2001. J Am Vet Med Assoc. 2002; 221: 1690-701. 
Lafon M. Immunology. In: Jackson AC, Wunner W. Rabies. San Diego:Academic Press; 2002. p.351-370.

Larghi OP, Delpietro HA, Málaga-Alba A, Smith JS, Wiktor TJ. Monoclonal antibody studies of rabies virus isolated from Argentina and Peru, South America. In:Traenhart $\mathrm{O}$, Koprowsky H, Bogel K, Sureau P, ed. Progress in rabies control. Kent, Wells Medical Limited, 1989.

Lee TK, Becker ME. Validity of spinal cord examination as a substitutive procedure for routine rabies diagnosis. Appl Microbiol. 1972; 24: 714-6.

Lentz TL, Burrage TG, Smith AL, Crick J, Tignor GH,. Is the acetylcholine receptor a rabies virus receptor? Science. 1982; 215: 182-84.

Lépine P, Atanasiu P. Histopathological diagnosis. In: Meslin F-X, Kaplan MM, Koprowski $H$. Laboratory techniques in rabies. $4^{\text {th }}$ ed.Geneva: World Health Organization, 1996. p.66-79.

Macruz R, Nilsson MR, Cortes JA. Raiva experimental em bovinos. Histopatologia do sistema nervoso central. Rev Fac Med vet Zootec Univ S Paulo. 1977; 14:123-7.

Málaga-Alba A. El vampiro portador de la rabia. Boletín de la Oficina Sanitaria $1954 ; 37$ : 53-65.

Marler RJ, Howard DR, Morris PG, Jonson JL. Rabies in a horse. J Am Vet Med Assoc. 1979; 175 : 293-4.

Martell MA. Estudio de inmunofluorescencia de diferentes segmentos de encéfalos de bovinos muertos de rabia paralitica $o$ derriengue en forma natural $e$ inoculados experimentalmente. Tec Pec Mex. 1969; 12:24.

Maserang DL, Leffingwell L. Single-site localization of rabies virus: impact on laboratory reporting policy. Amer J publ Health. 1981; 71:428-29.

Matsumoto, S. Electron microscopy of nerve cells infected with street rabies virus. Virology 1962; 17:198-202.

Mattos CA, Mattos CC, Smith JS, Miller ET, Papo S, Utrera A, Osburn BI. Genetic characterization of rabies field isolates from Venezuela. J Clin Microbiol. 1996; 34:155358 .

Mattos CA, Mattos CC, Rupprecht CE. Rhabdoviruses. In:Knipe DM \& Howley PM. Fields Virology. $4^{\text {th }}$ ed. Philadelphia; Lippincott Willians e Wilkins; 2001.p. 1245-1278.

Meslin FX. Situación de la rabia en el mundo, sin considerar a las Américas. In:Anais da XIII Reunión Internacional sobre avances en la investigación y control de la rabia em las Américas; 2002 nov 3-8; Cidade de Oaxaca (MX).Cidade de Oaxaca: 2002.p. 10. 
Meyer EE, Morris PG, Elcock LH, Weil J. Hindlimb hyperesthesia associated with rabies in two horses. J Am Vet Med Assoc. 1986; 188: 629-632.

Mifune K, Takeuchi E, Napiorkowski PA, Yamada A, Sakamoto K. Essential role of T cells in the postexposure prophylaxis of rabies in mice. Microbiol Immunol. 1981; 25: 895-904.

Milton JS. Statistical methods in the biological and health science. 2th McGraw-Hill. 1992.

Ministério da Agricultura, Raiva Animal. Boletim de Defesa Sanitária Animal. 2000; 28 : 55-60.

Ministério da Saúde. Fundação Nacional de Saúde. Guia de Vigilância Epidemiológica. Brasília(DF); 2002.2v.

Mitchell GC, Burns RJ. Chemical control of vampire bats. U.S.Bur.Sport.Fish. Wildlife Reserch Public. 1973. 37p.

Moreno AJ, Baer GM. Experimental rabies in the vampire bat. Am J Trop Med Hyg. 1980; 29: 254-259.

Murphy FA. Rabies pathogenesis. Arch Virol. 1977; 54: 279-97.

Nadin-Davis AS, Sampath MI, Casey GA, Tinline RR, Wandeler AI. Phylogeographic patterns exhibited by Ontario rabies virus variant. Epidemiol Infect. 1999. 123: 325-36.

Nadin-Davis SA, Sheen M, Abdel-Malik M, Elmgren L, Armstrong J, Wandeler AI. A panel of monoclonal antibodies targetting the rabies virus phosphoprotein identifies a highly variable epitope of value for sensitive strain discrimination. J Clin Microbiol. 2000; 38: 1397-403.

Nanayakkara S, Smith JS, Rupprecht. Rabies in Sri Lanka: splendid isolation. Emerg Infect Dis. 2003; 9: 368-71.

Nathanson N, Gonzalez-Scarano F. Immune response to rabies virus. In:Baer GM. The Natural History of Rabies. $2^{\text {nd }}$ ed.Boca Ratón: CRC Press; 1991.p. 145-61.

Niezgoda M, Hanlon CA, Rupprecht CE. Animal rabies In: Jackson AC, Wunner W. Rabies. San Diego: Academic Press; 2002.p163-218.

Nilsson MR, Sugay W. O uso de camundongos lactentes no diagnóstico da raiva. Arq Inst Biol. 1966; 33: 47-8.

Noah DL, Drenzek CL, Smith JS. Epidemiology of human rabies in the United States, 1980 to 1996. Ann Intern Med. 1998; 128: 922-30. 
[OPAS] Organizacion Panamericana de la Salud. Los anticuerpos monoclonales en la caracterización y vigilancia de los virus de la rabia en America Latina y el Caribe. Rev Panam Salud Publica 2000a; 3: 214-17.

[OPAS] Organizacion Panamericana de la Salud. Boletín Vigilancia Epidemiologica de la rabia en las Américas. Washington (DC) 2000b; 32: 40p.

[OPAS] Organizacion Panamericana de la Salud. Boletín Vigilancia Epidemiologica de la rabia en las Américas. Washington (DC) 2001; 32:40p.

Páez A, Nunez C, Garcia C, Bóshell J. Molecular epidemiology of rabies epizootics in Colombia: evidence for human and dog rabies associated with bats. J Gen Virol. 2003; 84:795-802.

Pasteur L. Méthode pour prevenir la rage apres morsure. C R Acad Sci 1885;101:765-72.

Peixoto ZMP, Cunha EMS, Sacramento D, Souza MCM, Queiroz da Silva LH, Germano PML, Kotait I. Rabies laboratory diagnosis: peculiar features of samples from equine origin. Braz J Microbiol. 2000; 31: 72-5.

Perl DP, Good PF. The pathology of rabies in the central nervous system In:Baer GM. The Natural History of Rabies. $2^{\text {nd }}$ ed.Boca Ratón: CRC Press; 1991.p. 164-188.

Queiroz Lima E. A transmissão da raiva bovina pelo morcego hematófago Desmodus rotundus. Brasil Medicina. 1934; 48: 38-40.

Rapp WR. Rabies in Kansas. J Kansas Medical Society. 1969; 70:483-6.

Raux H, Iseni F, Lafay F, Blondek D. Mapping of monoclonal antibody epitopes of the rabies virus P protein. J Gen Virol. 1997; 78: 119-24.

Robinson SJ, Disalvo AF. Rabies in South Carolina: 1969-1979. Public Health Lab. 1980; 38: $315-21$

Roehe PM, Pantoja LD, Shaefer R, Nardi NB, King AA. Analysis of Brazilian rabies virus isolates with monoclonal antibodies to Lyssavirus antigens. Rev de Microbiol. 1997; 28: 288-292.

Romijn PC, Van Der Heide R, Cattaneo CA, Silva RCF, Van Der Poel WHM. Study of lyssaviruses of bat origin as a source of rabies for other animal species in the state of Rio de Janeiro, Brazil. Am J Trop Med Hyg. 2003; 69:81-6.

Rupprecht CH, Hanlon CA, Hemachudha T. Rabies re-examined. Lancet Inf Dis 2002; 2: $327-43$.

Sacramento D, Bourhy H, Tordo N. PCR technique as an alternative method for diagnosis and molecular epidemiology of rabies virus. Mol Cell Prob. 1991; 5:229-40. 
Sacramento DR, Tordo N, Kotait I. Estudo molecular do vírus da raiva isolado no Estado de São Paulo. In:Anais da Reunião Anual do Instituto Biológico, 1994;São Paulo. São Paulo:Instituto Biológico; 1994.p.15.

Scarini P, Plazzi G, Gallo C, Cosimo N, Salfi M. Adelchi Negri (1876-1912). Pathologica. $1997 ; 89: 467-68$.

Scheifstein J, Topkins. Rabies in cattle-a technic for removal of the cerebellum for laboratory examination. J Am Vet Med Assoc. 1951; 119: 130.

Schlögel F. Breve histórico da raiva. Arq de Biol Tecnol. 1985; 28: 277-95.

Schneider LG, Dietzschold B, Dierks RE, Matthaeus W, Enzmann PJ, Strohmaier,K.

Rabies group-specific ribonucleoprotein antigen and a test system for grouping and typing of rhabdoviruses. J.Virol. 1973; 11: 748-55.

Schneider LG. Antigenic variants of rabies virus. Comp Immun Microbiol Infect Dis 1982; 5: 101-7.

Silva RA, Silva NM. Infecção rábica em cão com presença de vírus virulento nas glândulas salivares e avirulência no encéfalo. Pesq Agrop Bras Sér Vet. 1973; 8: 89-90.

Silva RA, Silva NM, Menezes PRV. Ocorrência do vírus da raiva na medula e no bulbo de eqüinos na doença natural e sua ausência nas diferentes regiões do sistema nervoso central e outros tecidos. Pesq Agrop Bras Sér Vet. 1974; 9: 29-31.

Smith LL, Claire A. A clinical note on equine rabies. Can Vet Journ. 1972; 13:193.

Smith JS, Reid-Sanden FL, Roumillat F, Trimarchi C, Clark K, Baer GM, Winkler WG. Demonstration of antigenic variation among rabies virus isolates by using monoclonal antibodies to nucleocapsid proteins. J Clin Microbiol. 1986; 24: 573-580.

Smith JS. Monoclonal antibody studies rabies in insectivorous bats of the United States. Rev infect Dis. 1988; 10:5637-43.

Smith JS. Rabies virus epitopic variation: use in ecologic studies. Advance Virus Res. $1989 ; 36: 215-53$.

Smith JS, Orciari LA, Yager PA, Seidel HD, Warner CK. Epidemiologic and historical relationships among 87 rabies virus isolates as determined by limited sequence analysis. $\mathbf{J}$ Infect Dis. 1992; 166: 296-307.

Smith JS. New aspects of rabies with emphasis on epidemiology, diagnosis and prevention of disease in the United States. Clin Microbiol Rev. 1996; 9:166-176. 
Smith JS. Molecular Epidemiology In: Jackson AC, Wunner W. Rabies. San Diego: Academic Press; 2002. p.79-111.

Soares RM, Bernardi F, Sakamoto SM, Heinemann MB, Cotez A, Alves LM, Meyer AD, Ito $\mathrm{FH}$, Richtzenhain $\mathrm{LJ}$. A heminested polymerase chain reaction for the detection of Brazilian rabies virus isolates from vampire bats and herbivores. Memórias do Instituto Oswaldo Cruz. 2002; 97:109-11.

Soave AO. Transmission of rabies to mice by ingestion of infected tissues. Am J Vet Res. $1966 ; 27: 44-6$.

Sokal RR, Rohlf FJ. Biometry: the principles and practice of statistics in biological research. 3rd ed., WH Freeman and Company, New York, 887 p.

Sokol F, Stancek D, Koprowski H. Strutural proteins of rabies virus. J Virol. 1971; 7:2419.

Souza MCAM. Infecção experimental de morcegos hematófagos Desmodus rotundus (E.Geoffroy) mantidos em cativeiro pela ingestão de sangue desfibrinado acrescentado de amostras de vírus da raiva. São Paulo; 2003 [Tese de doutorado - Faculdade de Medicina Veterinária e Zootecnia da USP].

Spearman C. The proof and measurement of association between two things. Am $\mathbf{J}$ Psycology. 1904; 15:72-101.

Statsoft Incorporation. Statistica for windows, release 5.1 (computer program manual). \{http://www.statsoft.com $\}$

Steece RS e Calisher $\mathrm{CH}$. Evidence for prenatal transfer of rabies virus in the mexican free tailed bat (Tadarida brasiliensis mexicana). J Wildl Dis. 1989; 25: 329-34.

Steele JH e Fernandez PJ. History of Rabies and Global Aspects. In:Baer GM. The Natural History of Rabies. $2^{\text {nd }}$ ed.Boca Ratón: CRC Press; 1991.p. 1-24.

Striegel P, Genetzky RM. Signs of rabies in horses: a clinical review. Modern Vet Pract. $1983 ; 983-5$.

Sureau P, Rollin P, Wiktor TJ. Epidemiologic analysis of antigenic variations of street rabies virus: detection by monoclonal antibodies.Amer J Epidemiol. 1983; 117:605-609.

Sureau P. History of rabies: Advances in research towards rabies prevention during the last 30 years. Rev of Inf Dis. 1988; 10:s581-84.

Sureau P, Ravisse P, Rollin PE. Rabies diagnosis by animal inoculation, identification of Negri bodies, or ELISA. In:Baer GM. The Natural History of Rabies. $2^{\text {nd }}$ ed. Boca Ratón: CRC Press; 1991.p.203-217. 
Tabel $\mathrm{H}$ and Charlton KM. The diagnosis of rabies in a horse by brain neutralization test. Can.J.comp.Med. 1974; 38:345-46.

Taddei VA, Gonçalves CA, Pedro WA, Tadei WJ, Kotait I, Arieta C. Distribuição do morcego vampiro Desmodus rotundus (Chiroptera, Phyllostomidae) no Estado de São Paulo e a raiva nos animais domésticos. Campinas. Secretaria de Agricultura e Abastecimento. Coordenadoria de Assistência Técnica Integral. 1991. 107p.

Takaoka NY. Raiva humana no Estado de São Paulo In: Resumos do Seminário Internacional de Raiva; 2003 ago 5-7; São Paulo. São Paulo: Instituto Pasteur; 2003.p.3536.

Tierkel ES and Atanasiu P. Rapid microscopic examination for Negri bodies and preparation of specimens for biological tests. In:Meslin F-X;Kaplan MM, Koprowski $\mathrm{H}$. Laboratory techniques in rabies. $4^{\text {th }}$ ed.Geneva: World Health Organization, 1996 p.5565 .

Tierkel ES. Investigación microscópica rápida de corpúsculos de Negri y preparación de muestras para las pruebas biológicas. In: Kaplan MM y Koprowski H. La rabia tecnicas de laboratorio. Genebra: Organizacion Mundial de La Salud; 1976. p.42-57.

Tizard IR. Vacinação e vacinas In: Imunologia Veterinária: Uma Introdução. $5^{a}$ ed.São Paulo: Roca; 1998. p.273-92

Tordo N. Characteristics and molecular biology of the rabies virus. In:Meslin F-X;Kaplan MM, Koprowski $H$. Laboratory techniques in rabies. $4^{\text {th }}$ ed.Geneva: World Health Organization, 1996 p.28-51.

Torres S e Queiroz Lima E. A raiva e os morcegos hematófagos. Morcegos que resistem à infecção tornam-se portadores e eliminadores de vírus? Revista do Departamento Nacional de Produção Animal 1936; 3:165-74.

Torres S e Queiroz Lima E. A raiva nos morcegos hematófagos (Desmodus rotundus murinus). Revista do Departamento Nacional de Produção Animal 1935; 2:385-406.

Trimarchi CV, Rudd RJ, Abelseth MK. Experimentally induced rabies in four cats inoculated with rabies virus isolated from a bat. J Vet Res. 1986; 47:777-80.

Trimarchi CV, Debbie JG. The fluorescent antibody in rabies. In:Baer GM. The Natural History of Rabies. $2^{\text {nd }}$ ed.Boca Ratón: CRC Press; 1991.p.220-229.

Trimarchi CV, Smith JS. Diagnostic evalution. In: Jackson AC, Wunner W. Rabies. San Diego:Academic Press; 2002.p.308-49. 
Tsiang $\mathbf{H}$. Evidence for an intraaxonal transport of fixed and street rabies virus. $\mathbf{J}$ Neuropathol Exp Neurol. 1979; 38:286-96.

Tsiang H, Lycke E, Ceccaldi PE, Ermine A, Hirardot X. The anterograde transport of rabies virus in rat sensory dorsal root ganglia neurons. J Gen Virol. 1989; 70:2075-85.

Tsiang H, Ceccaldi PE, Lycke E. Rabies virus infection and transport in human sensory dorsal root ganglia neurons J Gen Virol. 1991; 72:1191-94.

Uieda W, Hayashi MM, Gomes LH, Silva MMS. Espécies de quirópteros diagnosticados com raiva no Brasil. Boletim Instituto Pasteur. 1996; 1:17-35.

Van Regenmortel, M.H.V.; Fauquet, C.M.; Bishop, D.H.L.; Carstens, E.B.; Estes, M.K.; Lemon, S.M.; Maniloff, J.; Mayo, M.A.; McGeoch, D. J.; Pringle, C.R.; Wickner, R.B. Virus Taxonomy. Classification and Nomenclature of Viruses. Seventh Report of the International Committee on Taxonomy of Viruses. Academic Press, San Diego, California, 2000.

Veeraraghavan N, Balasubramanian A. Virus content of brains and submaxillary glands and occurrence of Negri bodies in animals suspected of having died of natural rabies infection. Bull Wld Hlth. 1958; 18:469-71.

Villa AV, Sierra MG, Rodríguez GH, Islas VJ, Félix AM, Pino FV, Monroy OV, Flisser A. Antigenic diversity and distribution of rabies virus in Mexico. J Clin Microbiol. 2002; 40: 951-958.

Webster LT, Dawson JR. Early diagnosis of rabies by mouse inoculation. Measurement of humoral immunity to rabies by mouse protetion test. Proc Soc Exp Biol Med 1935; $32: 570-73$.

Webster WA, Casey GA. Diagnosis of rabies infection. In: Campbell JB, Charlton KM Rabies. Boston: Kluwer Academic Publishers; 1988. p.201-22.

Webster WA, Casey GA. Virus isolation in neuroblastoma cell culture. In:Meslin F$\mathrm{X}$;Kaplan MM, Koprowski $\mathrm{H}$. Laboratory techniques in rabies. $4^{\text {th }}$ ed.Geneva: World Health Organization, 1996 p.96-104.

West GP. Equine rabies. Equine vet J. 1985; 17:280-282.

[WHO] World Health Organization Expert Committee on Rabies. Eighth report. Geneva, 1992. (WHO Technical Report Series, 824).

[WHO] World Health Organization. Workshop on Genetic and Antigenic Molecular Epidemiology of Lyssaviruses. Niagara Falls, Canada: World Health Organization, 1994 p.7. 
Wiktor T J, Gyorgy E, Schlumberger D, Sokol F, Koprowski H. Antigenic properties of rabies virus compenents. J Immunol. 1973; 110:269-76.

Wiktor T J, Kamo I, Koprowski H. In vivo stimulation of rabbit lymphocyte after imunization with live and inactivated rabies vaccines. J Immunol. 1974; 112:2013-9.

Wiktor T J, Doherty PC, Koprowski H. In vitro evidence of cell-mediated immunity after exposure of mice to both live and inactivated rabies virus. Proc Nat Acad Sci. 1977; 74:334-8

Wiktor TJ, Koprowski H. Monoclonal antibodies against rabies virus produced by somatic cell hydridization:detection of antigen variants. Proc Natl Acad Sci 1978; 75:3938-42.

Wiktor T J, Flamand A, Koprowski $\mathrm{H}$. Use of monoclonal antibodies in diagnosis of rabies virus infection and differentiation of rabies and rabies-related viruses. J Virol Methods, $1980 ; 1: 33-46$.

Wiktor TJ, Koprowski H. Antigenic variants of rabies virus. J exp Med 1980; 152:99-112.

Wilkinson L. History. In:Jackson AC, Wunner W. Rabies. San Diego:Academic Press; 2002.p.1-21.

Wilkinson L. Understanding the nature of rabies: an historical perspective. In:Campbell JB, Charlton KM Rabies.Boston: Kluwer Academic Publishers; 1988. p.1-23.

Wright R, Jansen J.Rabies and horses [on line]. Ontario: Ministry of Agriculture and Food; 2001. Available from $<$ http//www.gov.on/ca/OMAFRA/english/livestock/horses/facts/ info_rabies.htm>

Wunner WH. Rabies virus. In: Jackson AC, Wunner W. Rabies. San Diego:Academic Press; 2002. p.23-77.

Zanetti CR. Avaliação da imunidade celular anti-rábica,induzida pela vacinação, através da dosagem de interleucina-2. São Paulo;1994 [Tese de Doutorado - Escola Paulista de Medicina].

Zar JH. Biostatiscal analysis. $4^{\text {th }}$ ed., 1999. Prentice Hall, New Jersey, NY. 
ANEXOS 

ORGANIZAÇÃO MUNDIAL DA SAÚDE

Anexo 1 - Raiva Humana. Brasil, 1986 - 2002

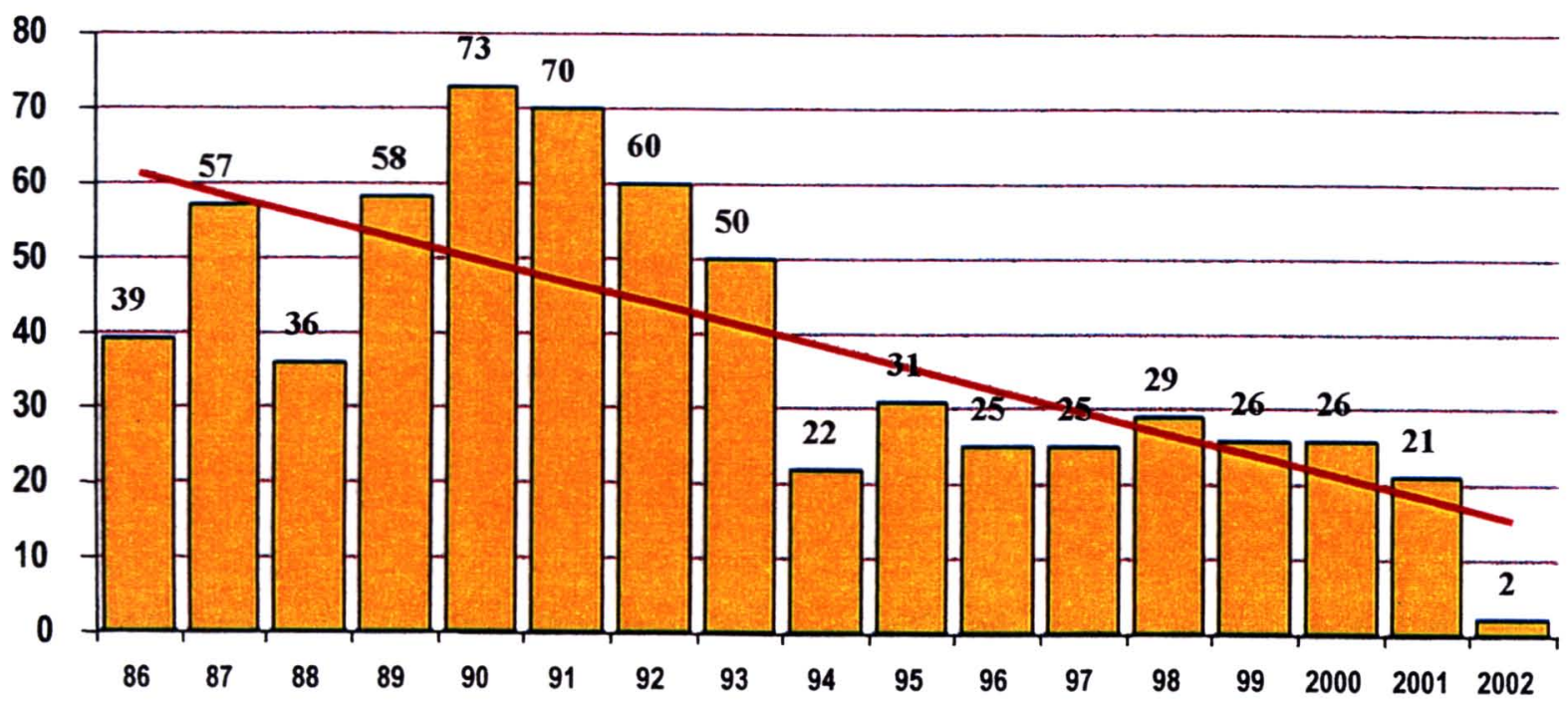

2002 - abril

Fonte: CENEPI/FUNASA/MS

Anexo 2 - Raiva Canina. Brasil, 1991 - 2001

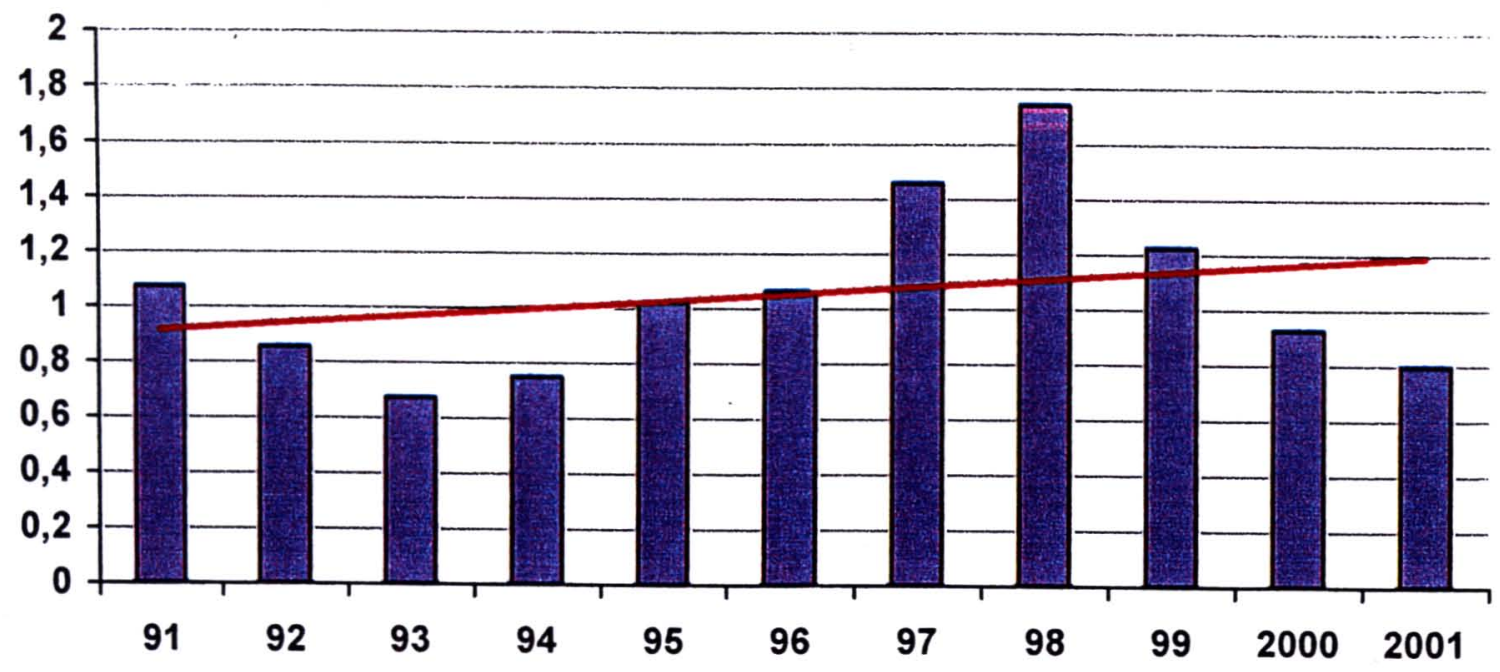

Fonte: CENEPI/FUNASA/MS 